\title{
The Collected Works of Charlotte Evans 1841-1882 Introduction and Biography
}

\section{By}

\section{Anne Doreen Brown}

\author{
A thesis \\ submitted to the Victoria University of Wellington \\ in fulfilment of the \\ requirements for the degree of \\ Master of Arts \\ in English \\ (NZ Literature)
}

Victoria University of Wellington 2010 


\section{Abstract}

This thesis provides an introductory view of the life and works of early New Zealand romantic novelist Charlotte Evans 1841-1882. The work is comprised of three separate sections, including two introductions, a biographical essay and footnoting and markup for digitisation. Evans wrote short stories in addition to novels and poetry. I have attempted to create here a useful and informative overview of her two published novels Over the Hills and Far Away: A Story of New Zealand and A Strange Friendship: A Story of New Zealand - each of which were published in 1874. In the biographical essay I include a discussion of Evans' general works, in particular the collection of poetry published by her husband Eyre Evans in 1917 entitled Poetic Gems of Sacred Thought. An important feature of the thesis has been to establish how Evans' range of literary output may be cited and contextualised within New Zealand's literary heritage in more detail than has previously been available. A significant aspect of the research has, in addition, involved examining the social and historical influences surrounding the author, both prior to and at the time of writing. In that respect the discussion has drawn upon available materials, such as book reviews and items published in newspapers. An appendix has been compiled of selected published poetry and articles from the North Otago Times of relevance to the foregoing text discussion. Contemporary photographs of Evans and map material of the 'Teaneraki' district are also included.

It is hoped that situating the research evidence to specifically New Zealand contexts may provide a basis for positing Evans' works more fully as New Zealand texts in their overall relation to pioneer period fiction. An important feature of the project has therefore meant developing a foundation of historical work concerning the author, much of which has been sourced from the National Alexander Turnbull Library and recently published family history that draws upon archive material related to the Evans and Lees families. Due reference to a range of recent critical texts has also, it is further hoped, enabled a more in-depth and detailed response to Evans' contribution to the developing field of New Zealand literature and more specifically, Victorian Studies. 


\section{Introduction}

\section{The NZETC Digital Project}

A major part of this thesis project has involved a close cooperation with the NZETC Text Centre at Victoria University. This has been facilitated through the introduction of the New Zealand Novels Digital Collection (that now makes New Zealand's earliest literary texts accessible to both readers and researchers (http://www.nzetc.org).

The NZETC project has been an integral feature of Humanities and Social Sciences since 2002/2003. The idea for such a digitisation project began through the assistance and initiatives of Elizabeth Styron, a Fullbright Scholar from Virginia USA. Following a period of research with the Virginia Electronic Text Centre, it was thought that a similar model could work in New Zealand.

The first project of the NZETC centre was the official history of New Zealand during the Second World War. Since then the work of the collection has expanded to comprise more than a 1000 books, representing almost 200,000 printed pages (http://www.nzetc.org).

The aim of the NZETC digitisation project has been to make textual-based material of interest to the New Zealand and Pacific audience freely available. This includes not just previously printed material but also 'born digital' (i.e. not previously written) material (http://www.nzetc.org).

The NZETC collection is an ever growing informational resource which currently (as of May 2009) has around 185,000 web pages, equivalent to approximately 160,000 pages of printed material. The NZETC is also a founding partner in the 'Matapihi' project and an active member of the 'National Digital Forum', the 'Text Encoding Initiative Consortium', and the 'Australia New Zealand Digital Encyclopedias Group' (http://www.nzetc.org).

The NZETC is engaged in an ongoing programme of digitisation with an expanding online library. The collection is delivered through an Open Source framework that offers full and free access to a range of ma5terials existing in multiple formats. As a 
continuing part of the Victoria University of Wellington Library, one of the text centre's key relationships is with the wider University, which in turn involves funding support. The NZETC works actively with VUW staff, students and academics on digital humanities research projects. This ensures that digital content will continue to develop and support ongoing research (http://www.nzetc.org).

\section{Aims and Structure of NZETC}

To create a digital library providing open access to significant New Zealand and Pacific Island texts and materials. This encompasses both digitised heritage material and borndigital resources (http://www.nzetc.org).

To effectively partner with other organisations, as a collaborator and service provider, on a variety of digitisation and digital content projects (http://www.nzetc.org).

To build a wider community skilled in the use and creation of digital materials through teaching and training activities and by publishing and presenting the results of research (http://www.nzetc.org).

To work at the intersection of computing tools with textual material and investigate how these tools may be used to make new knowledge from our cultural inheritance (http://www.nzetc.org).

\section{Digitisation and Markup}

The texts involved in this project are converted to online text using a markup method entitled 'TEI xml acronym' which is a form of encoding (see website: www.tei-c.org). The use of TEI provides a vocabulary and grammar to semantically markup a text so that it can be repurposed to almost any desired format. The editing of XML allows work to be taken and converted into a webpage. The text is also to be made available as an 'ebook' which, it is anticipated, will be 'more or less future-proof' (http://www.nzetc.org).

\section{The NZETC Collection}

Although much of the collection is comprised of previously-published material, significant parts of the NZETC collection, such as Kotare and Turbine, are 'borndigital'. Of the previously-published material, much is historical (such as The Encyclopedia of New Zealand) and does not therefore represent contemporary opinion or fact. It is considered important that researchers be able to access the text as it was 
originally published. The texts are therefore presented as they were published, making no attempt to correct or make amendments for reasons of spelling, factual correctness or otherwise. In so doing it is hoped that researchers may expand their understanding and knowledge of various features of editorial and print production in addition to historical opinion and social mores. Copyright considerations do however influence the introduction of contemporary material which can limit the introduction of new material into the collection (http://www.nzetc.org).

\section{Manuscript Material}

Most of the historical material in the NZETC collection is sourced from printed resources, though there are some parts of the collection which are based on manuscript documents (such as the John Cawte Beaglehole letters and Cox's Diary). However, the effort involved in transcribing manuscript material (which is done manually) precludes a large amount of manuscript material from being available on site (http://www.nzetc.org).

\section{NZETC New Zealand Novels Digital Collection}

The NZETC Online Novels Collection is now a well established and integral feature of the overall services provided by the digitisation project. The collection features numerous titles from the 'rare' category of early New Zealand novels of the 'Early Colonial' and 'Late Colonial' periods. The authors featured in the collection include the earliest among New Zealand's authors, for example: Henry Butler Stoney Taranaki; Clara Cheeseman A Rolling Stone; Emilia Marryat_Among the Maoris; F E Renwick Craigelinn; A Hood Dicky Barrett: With his ancient mariners; George H. Wilson Ena; or the Ancient Maori; B L Fargeon Grif: A Story of Colonial Life; and Jesse Weston Ko Meri; or, A Cycle of Cathay (http://www.nzetc.org).

The collection of novels are now among a general list of more contemporary 'born digital' works by New Zealand critics and authors. Access is available on the following website: http://www.nzetc.org/tm/scholarly/literature.html.

\section{Online Literary Projects - NZETC}

The School of English, Film, Theatre and Media Studies (of which this thesis is part) has collaborated with the NZETC on several research and publishing projects including an electronic edition of the poetry of William Golder, and an on-line electronic journal Kotare. Although much of the collection is comprised of previously-published material, 
significant parts of the collection (such as Kotare and Turbine) are born-digital, having no print incarnation. NZETC also collaborates each year with students from the International Institute of Modern Letters to produce Turbine, a literary journal, and the annual collection of Best New Zealand Poems. The J C Beaglehole Room is another important partner for the NZETC and a major source of the heritage material that is digitised to form the online collection. The Wai-te-ata Press, the NZETC and the J C Beaglehole Room have also collaborated with the NZETC on the Print History Project (http://www.nzetc.org).

\section{Papers Past}

The digitisation of New Zealand's national newspapers 'Papers Past' has been a significant National Library of New Zealand contributor to the accessing of historic newspaper material for this thesis. 'Papers Past' has digitised at least 40 national newspapers representing the print culture of New Zealand. For this project, the newspaper referred to was The North Otago Times - the main newspaper for the Oamaru region. The digitisation of the North Otago Times dates back to 1864 . The use of 'Papers Past' in this project has been especially helpful in enabling material to be drawn upon for contextual purposes.

\section{New Zealand Novels: Charlotte Evans}

This thesis project is among the first to be included among the introductory work of the colonial novels collection. The unique nature of this project presentation has necessitated a somewhat different approach to a standard Master's thesis, in that the material has had to be formatted specifically for digitisation purposes. This has therefore included: training in TEI XML mark-up provided by the NZETC; and work on enhancing of existing digital editions of the texts Over the Hills and Far Away and A Strange Friendship: A Story of New Zealand through editorial glossing encoded using TEI (footnotes, cross-references, name mark-up for relevant people, places and texts etc.). The project has also meant that digitisation of other relevant resources (e.g. reviews, historical accounts of events mentioned in the novels, texts relating biographical details of the author, contemporary poetry) will be of additional long term relevance. Some of this auxiliary reference material is still awaiting full html digitisation and is part of an archive of Evans-related research materials. 


\section{Biographical Essay Section}

The second section of this thesis, the 'Essay in Literary Biography' is based upon the format of existing essays that have been published in issues of 'Kotare' (See: http://www.nzetc.org/tm/scholarly/tei-WhiKoIn.html). It is anticipated that the biographical essay here mentioned will also be published digitally as part of that collection. The biographical essay on Evans is, however, somewhat longer in length than those previously appearing in 'Kotare'.

\section{Thesis Format}

This project consists of three main sections:

1. Two introductory essays for Evans' novels published by Sampson Low, Marston, Low \& Searle, London, 1874:-

Over the Hills and Far Away: A Story of New Zealand

A Strange Friendship: A Story of New Zealand

2. One biographical essay.

3. Editing and digitisation of texts for NZETC (see 'Explanatory Notes')

In the writing of this thesis for the MA (NZ Literature) the main emphasis has been on an introductory style incorporating the inter-related features surrounding the life and writing career of the author. In addition to providing summaries of Evans' life and literary works there has been the collection and citing of a range of critical material i.e. biographical material, factual and publishing-related material.

The format and presentation of the thesis for bound purposes therefore consists firstly of the two novel introductions followed by a biographical chapter. The first introduction for Over the Hills and Far Away includes biographical information with some discussion of the author's particular literary genre - the 'sensation' novel - and its placement within a 'colonial' context. The following introduction for A Strange Friendship cites criticism and textual analysis specific to the novel only. The thesis' third section, the essay in literary biography, places emphasis on biographical elements 
with a wider discussion of Evans' general works, including her collection of poetry Poetic Gems of Sacred Thought which is here transcribed in full. All three sections involve some overlap of material although this has been kept to a minimum as, for digitisation purposes, each piece of introductory writing will be separately positioned alongside its relevant subject within the digital archive. 


\section{Acknowledgements}

My grateful thanks to Jane Stafford for her enthusiasm, knowledgeable supervision and inspiration in the preparation of this thesis. Thank you to Jason Darwin of the New Zealand Electronic Text Centre and staff of the NZETC for their patience and guidance. Thanks to staff of the National Alexander Turnbull Library, including the Department of Manuscripts. My appreciation to staff of the Waitaki District Council, in particular Shannan Carr, for their generosity. Thank you to Beryl Miller of Oamaru for her assistance and special thanks to Corry Skillbeck. Thank you also to administrative staff of the English Programme and Peter Whiteford. 


\section{List of Illustrations}

Figure 1: Drawing 'Journey to NZ - Map'

p. 12

(Skillbeck, C. Jottings of a Gentleman)

Figure 2: Title Page for Over the Hills and Far Away:

p.13

A Story of New Zealand (1874), NZETC Collection.

Figure 3: Preface for Over the Hills and Far Away

p.14:

A Story of New Zealand (1874), NZETC Collection.

Figure 4: Title Page for A Strange Friendship: A Story of New Zealand

p.42 (1874), NZETC Collection.

Figure 5: Front Cover for A Strange Friendship: A Story of New Zealand

p.43 (1874), NZETC Collection.

Figure 6: Illustration (NZETC Novels Collection)

p.60

Figure 6: Sketch 'Oamaru Athenaeum' and 'North Otago Museum'

(Courtesy, North Otago Museum, Waitaki District Council, Oamaru).

Figure 7: Photo 'Thames Street, Oamaru' 1905

p. 150

(Skillbeck, C. Jottings of a Gentleman).

Figure 8: Map 'Teaneraki' (Enfield) District

p. 152

(Skillbeck, C. Jottings of a Gentleman).

\section{List of Abbreviations:}

ASF: Charlotte Evans, A Strange Friendship: A Story of New Zealand (1874)

OHFA: Charlotte Evans, Over the Hills and Far Away: A Story of New Zealand (1874)

JOG: Corry Skillbeck, Jottings of a Gentleman. 


\section{Contents}

Abstract 2

Introduction 3

Acknowledgements 9

List of Illustrations and Abbreviations $\quad 10$

Table of Contents $\quad 11$

Section One: Introduction to Novels

Over the Hills and Far Away

$\begin{array}{ll}\text { Part I } & 15\end{array}$

Part II 23

A Strange Friendship

Introduction 44

Section Two: Literary Biography

$\begin{array}{ll}\text { Part I } & 61\end{array}$

$\begin{array}{ll}\text { Part II } & 81\end{array}$

$\begin{array}{ll}\text { Part III } & 89\end{array}$

Works Cited 122

Explanatory Notes $\quad 126$ 


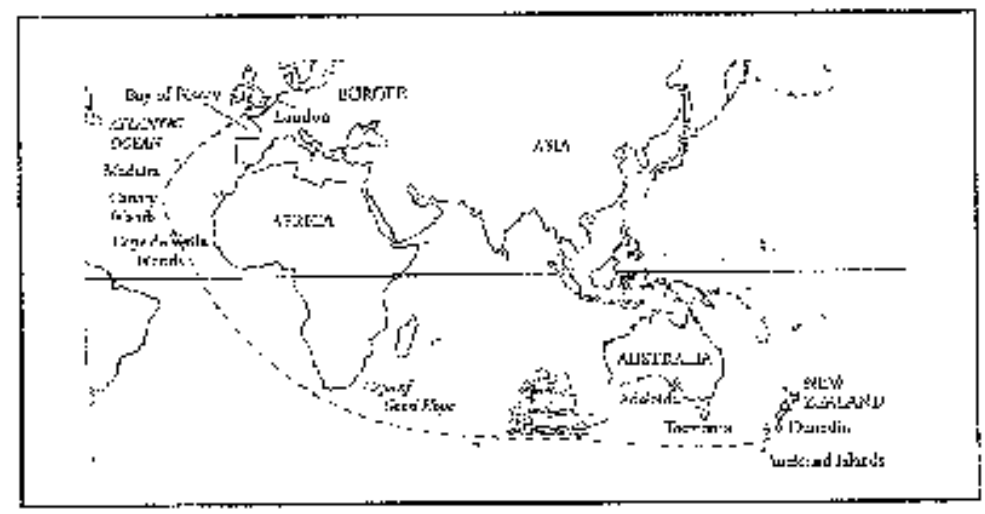




\title{
OVER THE HILLS, AND FAR AWAY:
}

\author{
A STORY OF NEW ZEALAND.
}

\author{
By C. EVANS, \\ AUTHOR OF "A STRANGE FRIENDSHIP," ETC.
}

Zonoon:

SAMPSON LOW, MARSTON, LOW, \& SEARLE, CROWN BUILDINGS, 188, FLEET STREET.

1874.

[All rights reserved.] 


\section{PREFACE.}

IN writing a story of New Zealand life, one great difficulty presents itself.

It is a life which in its social aspects is continually altering, as the country advances in prosperity and civilization. The colours in the kaleidoscope remain the same, but the pattern gradually changes.

In writing this story, I had in my mind the New Zealand of some years ago, with which I first made acquaintance. Since then much is altered. The land which lay waste and desolate is now fenced and under cultivation, and society has become more formal, and conforms more strictly to the rules in vogue in Europe. 


\section{Over the Hills and Far Away}

\section{Introduction}

\section{Part I}

Charlotte Evans was born in Oldham, England on 21 September 1841 as Charlotte Lees, one of four children of James and Sophia Lees (neé Ball) (ATL-MS-5135-03). The Lees were Lancashire cotton merchants who emigrated to New Zealand in 1864 to settle in Oamaru in the region of South Otago. Evans died at the age of 40, in Oamaru, on 22 July 1882. Like other women of the Victorian period she expressed her feelings for the written word in the form of 'stories, poems and hymns' (Skillbeck 65). Evans became the author of two of New Zealand's earliest romance novels, publishing both Over the Hills and Far Away: A Story of New Zealand and A Strange Friendship: A Story of New Zealand in 1874. An earlier work Guy Eversley was introduced to the local public in the Oamaru Times and Waitaki Reporter in serialised form between 1865 and 1866 . Unlike Evans' later writing, Guy Eversley's storyline with a male narrator still reflected Evans' familiar plot characteristics concerning marriage and Christian piety set amongst the colonial temptations of vice and greed (Moffat 19). In common with English emigrants to New Zealand Evans was strongly influenced by her Christian faith. It was a trait noticeable also among her wider body of published and unpublished work. 


\section{The Lees of Lancashire}

Evans' family the Lees came originally from Clarkesfield in the north of England, an area situated in the district of Oldham and recognised in the nineteenth-century for its cotton industry. Following a decline in cotton in the 1860's the family moved further south to live in the vicinity of Richmond in southern England (ATL-MS-5135-03). There Evans spent her girlhood holidays among friends and relations, becoming familiar with some of the better known landmarks of Devon and Sussex such as Plymouth and Dawlish Bay, both of which are mentioned in her novel Over the Hills and Far Away. In 1864 Charlotte's parents decided to emigrate to New Zealand since their two sons, Joseph and James, had already travelled ahead of them to South Otago. In 1864 the remaining Lees family consisting of James Snr., Sophia and their younger daughter Charlotte, finally left England aboard the passenger ship Chile. They arrived, several months later in November, at Port Chalmers situated in the southern region of Otago. The Lees brought out capital to invest which they succeeded in doing in an area outside Oamaru then known as 'Teaneraki' (later 'Enfield') (Skillbeck 58)). It was in the same vicinity that Charlotte met her future husband Eyre Evans, a young man from Trinity College, Dublin, who several years later accompanied his brother out to New Zealand. The couple were married at Teaneraki on 14 April, 1868. The wedding notice recorded that a Reverend Algeron Gifford officiated at the ceremony, mentioning Eyre as the 'eldest son of Captain George Evans and grandson of the late Eyre Evans, Esq of Ash Hill Towers County Limerick' and Charlotte as 'the youngest daughter of James Lees Esq Teaneraki' (ATL-MS-5135-09).

\section{Pioneer Novelist}

Evans is among the earliest of New Zealand's romantic novelists having a significant, though largely unrecognised, position as an early literary contributor to New Zealand's nationhood in providing escapist entertainment for a mainly overseas readership (ATL- 
MS-13-19-1). Her two published novels Over the Hills and Far Away: A Story of New Zealand (1874) and A Strange Friendship: A Story of New Zealand (1874) were modelled upon the 'sensation' novel, a new form of romantic melodrama then becoming popularised in the 1860's by the British journalist and author Wilkie Collins, with its own particular conventions (Jones 125). In addition to the novel form Evans produced a miscellany of writing including poems and a collection of short stories. A selection of her poetry was published posthumously as Poetic Gems of Sacred Thought (1917). Her short stories were published as three short novellas under the title Only a Woman's Hair (1903). All set in New Zealand, these stories were like the other romances and written in a style both 'highly contrived and melodramatic' (Moffatt 19). Evans' work also belongs to the genre of popular 'romance'; a version of which can be found in the recent Mills and Boon novel. The Mills and Boon romance, noted for its predictability and plot repetition with 'happy endings', is somewhat modified in Evans' writing through the sensation novel influence with which A Strange Friendship and Over the Hills and Far Away are associated.

\section{Sampson Low}

The publisher of Evans' novels was the London firm Sampson Low, Marston, Low \& Searle. Originally a bookselling and stationery business, the firm was founded in 1819 by a Mr Sampson Low, the son of a printer and publisher. Sampson Low's premises incorporated a circulating library and attracted a strong middle-class readership constituency. Patrons at the Sampson Low 'reading room' included professional as well as literary men, all of whom contributed to and supported what would become one of the nineteenth-century's more prolific publishers of fiction and non-fiction (Feather 12). By 1874, the year of Evans' novel publications, Sampson Low had moved his firm's premises to Fleet Street to form a partnership with Edward Marston. The breadth and scope of Sampson Low's influence was reflected in a range of New Zealand 'pioneer 
period' publications contemporary with Evans that featured fictionalised adventure narratives and non-fictional accounts of early New Zealand exploration (http://www.nzetc.org/tm/scholarly/subject-000005.html). In her publishing relationship with the Sampson Low firm Evans incorporated both an international and local dimension. As a New Zealand novelist contemporary within the wider arena of transnational publishing, she inhabited the same field as American novelists Louisa May Alcott and Harriet Beecher Stowe (whose depictions of American society parallel to some extent Evans' less detailed versions of the New Zealand colonists' milieu). Sampson Low was more famously also the publisher of Evans' fellow sensation writer Wilkie Collins and his acclaimed novel The Woman in White (1861).

\section{'Pioneer Period' Writer - 1861-1889}

The decade of the 1860's categorised by Lawrence Jones as the 'Pioneer Period' (Jones 120) places Evans among the very first New Zealand-based novelists to write locally, yet achieve international publication status. This formative period in New Zealand literature, though oriented toward the 'imperial centre', is considered to have been nonetheless 'vigorous, broadly based and central to the culture of the growing nation' both in its occasional reference to the rigors of colonial frontier society and, in Evans' case, as a romance novel that could provide an antedote to the 'dangerous unpleasantness of realism' (Stafford and Williams Introduction: A Land Mild and Bold). As an early New Zealand author working both physically and imaginatively within an evolving national landscape, Evans' novelistic outlook sought wherever possible to incorporate at least some of the indigenising features pertinent to a 'Story of New Zealand'. Evans addressed the difficulties experienced in confronting the changing New Zealand colony as a literary subject mentioning in her 'Preface' (in which she refers to her contemporary, the English novelist Charlotte Bronte) that the [colony's] 'pattern gradually changes' (OHFA 'Preface'). Though conforming to an 'inherited 
genre' of literary style that was aimed essentially for an established Empire audience Evans formed, in both her novels and collection of stories, at least some reliance upon an 'ad hoc' use of New Zealand material termed 'exploitative conventionalism' (Jones 122). This often took the form of a narrative 'punctuation' or periodic insertion of the 'exotic' (as for example, in the giving of a Maori name to the Cunningham's station home of 'Maungarewa', or casual mention of food with a name as strange as 'pokekhas') (OHFA 213)). As a result the overall landscape in Evans' use of the exotic began to assert a sense of 'place' that was yet strange, which haunted the background of a novel that was also a 'story of New Zealand' (See title).

\section{Sensation Novel}

The sensation novel genre since associated with Evans was a 'popular sensation' also among the middle-classes of the mid-nineteenth century that worked 'directly on middle-class anxieties about the status and stability of class identity' (Thomas 180). It embodied an arena of interest also in the 'fantastic' and 'gothic' of the Victorian novel which could assume various forms. In addition the sensation novel incorporated elements of the 'sensational' and 'fantastic' with a 'Victorian realism' (Pykett 193). It became an ephemeral and popular genre not 'easily assigned to a single generic category' (193). As Pykett states in The Cambridge Companion to the Victorian Novel, the forms of the fantastic 'proliferated into a range of fictional genres and sub-genres, many of which had originated from the various strands of late eighteenth-century gothic romance' (192). As a type of sensation writing related to the pioneer period, Evans' work may also be seen as a sub-genre of the ‘sensation' phenomenon. Her own milieu of colonial Oamaru was itself a society reliant for its identity and changing cultural structure upon 'inherited' literary forms such as romantic and adventure tales. It is thus likely that the 'penny dreadful' or 'weeklie' from which the sensation novel took its 
inspiration would also have found its way on to the township's counters and bookshelves (Flint 29).

When perceived in terms of cultural milieu, the 'localised' sensation novel belonging to Evans' could also have been an indicator as to what was transgressive, or subversive, in social behaviour. Explored in her writing were the middle-class settlement themes of courtship, marriage and property, all of which betokened a society wherein social mobility affected middle-class and working class settlers alike. Potentially, crime and 'sensation' lay at the periphery of recognised norms of behaviour, threatening the ideal order of events. For the colonial romance, these elements constituted features of risk and escapade which were to some extent synonymous with the hint of new social freedoms surrounding the foundation of the colony. Indeed Evans' novel themes can be viewed as portraying similar sentiments toward settler aspiration as those promoted by Wakefield's New Zealand Company (Sturm 51). The sensation novel was a portent of change also for more traditional forms of romance, particularly in its hero and heroine archetypes. Evans' 'subversive' female characters guaranteed no moral certainties, but were instead vulnerable to the social and emotional impulses of a shifting society and thus able to become enmeshed in seduction and crime. Such a figure occurs in Evans' use of Violet Somerset in A Strange Friendship. Again, it is in her depictions of the colonist's milieu that Evans achieved her own uniqueness sourced from the peculiar circumstances of the colony and its shifting imperatives.

A central concern of Evans' narratives was the settlers' desire and expectation of combining a civilised life in the colony with the familiar social and material benefits enjoyed in England (at least for those of the middle-classes). However, as shall be seen in the outworkings of Evans' sensation plot, 'colonial' romance also identifies strongly with the right, or wrongful, choice of marriage partner and the dire effects brought about 
by injudicious behaviour. This is seen again in Violet Somerset's elopement in $A$ Strange Friendship. In fact as local newspaper reports may demonstrate, fiction and 'reality' could, and sometimes did, overlap in the everyday life of a colonial society haunted by the social concerns of drinking, temperance, the inherited and the disinherited. Evans' husband Eyre contributed numerous articles on temperance, which as a subject arose in particular as one of the manifestations of a 'frontier' society (JOG 96). Concern over the effects of public alcohol consumption may also have pointed to the deeper issues or insecurities that drove the colony; as for example in the need for a law-abiding and productive population. Transgressing across these boundaries were the types of scenario to be found in Evans' novels; in the disaffected hero of Alan Ainsleigh, unable to marry appropriately or settle down, or the fraudster 'on the loose' in Richard Carewe (A Strange Friendship). The effect of this form of popular literature on the wider reading population was further demonstrated in an article, published in the North Otago Times in 1874, which shed further insight upon local misgivings as to the 'hidden' questionableness of the sensation form. Alluding to the 'tone' of the writing as 'essentially false', the article examined how crime was being vindicated through presentations of character that edified persons as 'great, or strong, [or] clever, or beautiful' (North Otago Times [October 15]:1874).

\section{Sensation Writer}

Evans' impetus toward writing in the sensation genre may have been influenced in addition by prevailing currents in the shifting transtasman population typified in newspaper reports that depicted subversive life in the colony. In Evans' lifetime articles appeared from time to time in the Oamaru newspaper the North Otago Times, on the more unusual instances of 'bigamy' and, more regularly, on escaped 'villains' such as the 'notorious scoundrel' John Buchanan (North Otago Times [May 26]:1874). Evans' own position as a known local literary figure and writer of romance with a touch of the 
risqué also suggested differing perspectives with a local and international dimension. As a New Zealand-based contemporary of Wilkie Collins, whose works were written during the 'sensation decade' of the 1860's, Evans was a woman of middle-class respectability domiciled in the distant locale of Oamaru, New Zealand. If there was any discomfiture in her being a writer of sensation fiction local newspaper reviews appear to have avoided this suggestion, tending rather more to concentrate on plot and thematic content, than the novelist herself. A contemporary article did proffer the injunction however that 'this sensation writing' had to a certain extent 'already demoralised a portion of society' (North Otago Times [October 15]:1874).

To what extent Evans either consciously or otherwise wrote or imitated Collins' style is uncertain. Her having written in a genre contemporary to that of a major British writer, in a place so geographically distant and in the same decade, is at least worthy of note. In Evans' instance, newspaper culture would appear to have been the principal arbiter in her local reputation as an authoress. At that time any form of public debate (i.e. public talks, lectures) was at a minimum and more likely to have been held at the Oamaru Athenaeum and Mechanics Institute.

\section{North Otago Times}

The Oamaru Athenaeum and Mechanics Institute which in Evans' lifetime was only at the beginning of its development, existed at the periphery of a flourishing newspaper industry dominated by Oamaru's newspaper the North Otago Times. Articles published in the North Otago Times had an air of the transnational - or more particularly transtasman - presence of nearby Australia, between whose ports flowed numerous immigrants either to or from New Zealand. Both the colonies of New Zealand and Australia were then in the midst of establishing their state and provincial boundaries with the prospect of Federation never far from political discussion. During Evans' years 
of authorship of the 1860's-1870's Australian Federation was yet some 30 or more years off. It was the era of transtasman publishing that came to be known as 'Maoriland', when Melbourne publishing houses constituted a significant portion of the Empire publishing market for Australia and New Zealand (Stafford and Williams 11). Whilst attending to more local concerns the North Otago Times of the 1860's appears, nonetheless, to have been readily accepting of its shared colonial kinship, not just with Australia but also with America, whose civil war was then in progress. All three nations shared a relationship with frontier culture. Though of smaller size and population, New Zealand demonstrated its own similarity in settlement and social patterns with that of the western United States. To that effect the North Otago Times sometimes republished feature articles on notorieties, public scandals and murders being reported in California and Australian newspapers, thus providing the background for the type of sensation novel written by Evans (see 'The Man with Two Wives' North Otago Times [May 14]: 1874).

\section{Part II}

\section{Reviews}

The reception given to Evans' first novel by contemporary newspaper reviewers indicates both the advent of a 'colonial' literature and a need to introduce a new form of sensationalism in popular fiction. In the genre of the sensation novel could be found the elements of crime and romance, each offered in an expedient style suited to a growing readership, whose needs corresponded to a period of social change. Over the Hills and Far Away received two favourable reviews in the year of its publication. In the first, dated February 1874, J.G. Flatt of Oamaru gave a descriptive account of the novel's storyline, providing a brief opinion of the novel's overall character. 
Flatt's initial impression conveyed that Over the Hills was a 'simple story, well and gracefully told' with 'pretty descriptive passages'. His opinion was qualified further in the observation that the book was still 'somewhat sketchy and without complication of by-plot' yet nonetheless 'very readable'. In reference to Evans' use of New Zealand material Flatt's review noted the author's ability to evoke 'New Zealand scenery and New Zealand life' as wrought with the 'hand of an artist who evidently loves her task' (North Otago Times [February]: 1874).

A clipping of a second (undated) review for Over the Hills and A Strange Friendship (North Otago Times) pertinently observed that the scenes or location of Evans' stories were fundamentally unrelated to the plot of the novel, stating as follows:

Both of the books before us purport to be stories of New Zealand-that is to say, the scene of each is laid in this colony-but although this is the case, so far as the plot is concerned the scene of action might have been anywhere, for in neither work does the story hinge upon any peculiar phase of colonial life. Review North Otago Times (ATL-MS-5135-09).

This review pronounced New Zealand as the 'residence' nevertheless of the 'creatures of Evans' fancy'. Her saccharine yet faintly indigenised landscape was thought to offer the Empire readership 'pictures of colonial life' that were both 'refreshing' and presented with 'great vividness and a minuteness of detail'. Written from the Empire viewpoint, this particular review clearly found Evans' version of the colony and its natural scenery more than adequate for the 'uninitiated' reader overseas and even for those readers in New Zealand. It appeared that Evans could offer a differently nuanced idea of the colony than was usually available in emigration propaganda - as the following opinion suggests:

Both books contain descriptions of our New Zealand scenery, introduced naturally, and depicted truthfully. The author evidently loves 
her adopted land, yet there is none of what we may call the emigration agent style of touting introduced, but we see her regard for even New Zealand's rugged ranges in such words as these, put into the mouth of one of her characters: 'I shall see no hills in England that will find their way to any heart like those' Review North Otago Times, 1874.

The review also brought to notice, in its citing of Evans' romantic sense of the New Zealand landscape, an attempt at a 'new belonging' in the transcription of the English 'sublime' into the colonial vista. A comment subsequently made by the reviewer then posited the idea that Evans' novels might have constituted a hybrid novel form, in the following remark, which hints that the novels were able to focalise newly 'indigenised' behaviours, customs and scenery for the settlers themselves:

We have so few books of this class that it still seems strange to read of things which we think nothing of when enacted around us daily, but which at once strike us as being peculiarly colonial when we meet them in the course of an interesting story - Review North Otago Times, 1874.

In this second review where Over the Hills is compared with A Strange Friendship the latter is thought to be of greater interest with a more 'cleverly conceived' plot. The 'diversity of character', however, is praised in both. Evans' arrival as a newcomer in the emergent field of colonial novels was heralded, with appreciation given for the less descriptive and more spare style of Evans' narrative, for which there was 'no mere padding' and thus the reader would have 'no occasion to wade through or jump over tedious parts'. The review's summing up of Evans' contribution to a fledgling 'colonial literary industry' reflected an underlying opinion that the books belonged to the genre of light popular fiction. They were, after all, a 'pleasant book to pass a leisure hour' (ATL-MS-Papers-5135-09). 


\section{Introduction to the Novel}

Over the Hills and Far Away consists of 33 chapters, with a short 'Preface' by the author and a page dedicated to her husband Eyre Evans. A brief survey of the plot of Over the Hills and Far Away sees the following: Lucy's departure from England accompanied by her brother Louis followed by the ship journey aboard the 'Flora McDonald' and Lucy's arrival and introduction to life in the colonies (Chapters 1-8) The appearance of the Winstanleys and Lucy's meetings with the Lennoxes at Deepdene then involve a working out of marriage plots concerning the Cunningham and Lennox families. The two outsiders Rylston Dacre and Laura, however, complicate Lucy's feelings of attachment to her shipboard 'fiancée' Clinton Meredith and instigate a covert, but growing affection between Lucy and Dacre. The resulting love triangle then ends in the climactic resolution of the suspense sub-plot regarding Laura's identity and Dr Dacre's past, as the novel's resolution of the marriage plot concerning Lucy is finally effected in a Christian theme of redemption (Chapter 33).

\section{Genre}

As a form of novel genre Over the Hills and Far Away incorporates aspects of the classic realism normally associated with fiction (David 192), while also following in the format of the sensation style popularised by Wilkie Collins; the writer and journalist contemporary of novelist Charles Dickens. Her novels were published during what is commonly referred to as the 'sensation decade' (David 1). Collins was noted for his adoption of gothic, romance and melodramatic elements to create a sensational form of writing which addressed popular court cases and themes of criminality (Jones 120). The Collins style of the popular novel encouraged the development of a certain form of modern storytelling. Based in contemporary settings and involving an experimentation with the violation of Victorian sexual mores, or accepted conventions of the bourgeois code, the sensation novel's narrative placed female characters in crime drama scenarios 
for which narrative disclosure became, in addition, a form of 'dissecting' the feminine (Flint 25). Collins' novels also, like Evans' colonial versions, addressed male melancholia, the position of women within marriage and the 'domesticated gothic'. All these factors are recognisable within Over the Hills in the following chapters: in 'The Slope' (Chapter 31) involving the hidden guilt and anxiety of Rylston Dacre; in 'The Third Time' (Chapter 11) the portrayal of Laura in the domestic interior of her 'dark sitting room' in a final confrontation with Dacre and Louis Cunningham (Chapter 11); and the trials of Lucy toward womanhood, culminating in the closing chapter 'Forgiven' (Chapter 33).

\section{The 'Diasporic' Novel}

Evans' insertion of detail concerning emigration and ship journeys with that of social custom also confirms her attention to the mode of 'classic realism' (David 65). This is noticed more particularly in the novel's opening chapters concerning the Cunningham's departure from English shores which refer specifically to the cities and ports of southern England such as Brighton, Plymouth and the coastal cliffs of Sussex (OHFA 30). Once aboard the 'Flora MacDonald' the features of shipboard life, undoubtedly drawn from Evans' own travel experiences, begin to colour the story. Based on simple day to day interactions, the diary Lucy writes aboard the 'Flora MacDonald' obeys the Victorian diarist's convention of daily observances of people and cabin arrangements, weather patterns and leisure reading (see Chapters 2-7 'Lucy's Diary'). Amidst these scenes of shipboard activities and the forming of new acquaintances, Evans developed her future plot scenarios regarding romance and relationships between the home country and the colony soon to be established. In the naiveté of its descriptions of shipboard romance and arrival in the colony with meetings on horseback, Evans' narrative directed itself toward a vision of landscape and people that was 'escapist', while also containing elements of realism. The escapist element formed itself particularly around the 
reconstituting of an idealised colonial landscape when, upon disembarkation at Port Chalmers, the characters' former ties with their home country appeared to swiftly reestablished themselves - with seemingly little or no sense of intervening time, distance or physical effort. Of the progress of colonisation in her own area of Otago Evans wrote: 'The land which lay waste and desolate is now fenced and under cultivation' ('Preface'). Subsequently, in her novel on the colonial farm, is found the saccharine vista of Evans' conventionally idealised New Zealand landscape of home-like features, including 'English grass' (79), lawns, fences and 'enclosed' gardens (79).

\section{Plot Features}

Evans' exploitation of plot in the sensation genre emphasises certain features mentioned by Lawrence Jones i.e., the crimes and secret past separating hero and heroine; an emphasis on the 'unravelling of a mystery' (Jones 125) and use of false identity; the 'documentary method' (125) of telling the story with 'partial perspectives' (letters and journals) (125), as well as the effect of shock and surprise and use of evocative settings. The influence of the sensation novel and a break with usual social boundaries begins to be felt in (Chapter 1) when after a protected life spent in the company of her aunts, Lucy's breaking of ties with England among a group of strangers appears to plunge her into an adult world of hidden intrigue and romantic possibility fitting the gothic stereotype, yet alleviated by the 'lighter' tone of the sensation narrative. While Lucy is ostensibly meant to be under the male protection of her brother Louis she often paradoxically appears to risk flirtation with a range of other male characters, the observations of whom she enters into her diary in ladylike fashion (see Chapters 2-7). For the Victorian traveller, and most particularly the young unmarried woman, a ship journey was clearly symbolic of encounter beyond normal social horizons. This is evidenced in Lucy's early flirtation with Clinton Meredith and anticipation of life in the colonies. In the opening chapters of emigration to the 'colonies' the ship becomes its 
own 'social cocoon'. Evans then manages to find scope for a delectating 'pas de deux' of amorousness, flirtation and worldly intrigue whilst maintaining a semblance of Victorian moral respectability. The question might then be raised as to the future meaning of the colony for the characters: is it to be a distant locus of escapism, of the socially dissident and 'unsanitary', or the place of prosperity, fortune and marriage?

A central preoccupation of Evans' characters would then appear to lie in the uncovering and restitution of their various past relationships in England. The freshness of the colonial vistas, though inviting, nonetheless contain shadows of secret dilemmas, providing the necessary ingredient of spice and intrigue anticipated by the Empire reader, as the colonies themselves become the scenario for a working out of sexually triangular relationships. In this respect, Evans staged much of her narrative action between the two geographical points of reference of Maungarewa and Deepdene, both of which serve as picturesque settings for a series of romantic episodes involving hidden desire (when can Dacre fully reveal his feelings), death scenarios (the 'sudden' death of Effie (192)) and marriage contracts and flirtations which see Mrs Lennox becoming confidential (see Chapter 15) - with all the scenes set amidst imported drawing room splendours. Using the now colonial family associations of the Lennoxes, the Priors and the visitors Winstanley and Dacre, Evans continued to sustain a web of romance subplots and mini dramas, during which characters are not allowed to be fully aware of each other's hidden relationships or feelings. This is so particularly in the sub-plot of Clinton Meredith's flirtation with the Lennox sisters in (Chapters 15-18), as Clinton's intentions come under increasing scrutiny followed by his eventual admission to having had a former love in England. On another subversive note is the sub-plot concerning Dacre's tantalising former association with Laura, linked in the plot through the Brighton letter. The said clue first appears in the chance encounter between Lucy and Laura, prior to Lucy's departure, when she inadvertently picks up the letter about to be 
posted to Dacre. The letter then later reappears in the chapters surrounding Laura's full disclosure of her identity.

A further interesting and perhaps more subtle feature of the Evans plot is the apparent superficiality of the romantic interlude and tacit engagement of Lucy to Clinton Meredith, which in the succeeding chapters, is eventually to assume an increasingly complex and subverted character. This takes the form of Lucy's passing attachment, in view of a delay over Meredith, to a number of other possible suitors. An underlying plot theme of romantic dilemma involving discernment and subterfuge then ensues, whereby relationships in New Zealand become further complicated with the emergence of the Priors and the 'apathetic' outsider Arthur Winstanley. The romance and sensation plot theme of marriage settlement in Over the Hills and Far Away is also to be found in the courtship of Effie Lennox and Clinton Meredith, carefully overseen by Mrs Lennox (who plays confidant to Lucy). However, Lucy's own journey towards a marriage settlement, being more circuitous and fundamental to the suspense element in the novel itself, is rather less governed by watchful family members. Lucy in fact lacks the conventional family pattern of the Lennoxes, with no mother still alive and an 'absent' father who has been settled in advance in the colonies. Similarly, in her round of courtship with several suitors, Lucy is able at times to demonstrate independent traits of discernment and self-possession. The narrative voice of Evans then assumes a 'mother figure' role for the heroine, with commentaries aimed to cast amused or critical judgement. In her working out of the sensation romance plot Evans employs the element of time effectively, allowing for both leisurely and realist descriptions of colonial habitation and custom (i.e. 'lavish' outdoor Victorian picnics and horseriding) whilst also introducing characters so as to culminate in pivotal episodes such as 'The Country Concert' (Chapter 14), or 'Lucy's Ride' (Chapter 20) and, finally, in the climactic 
scenes of the closing chapters involving 'The Picture' (Chapter 28), in which Dacre's and Louis' mutual entanglements with Laura are finally discovered.

In the final two Chapters, 'A Charge' and 'Forgiven', Laura's charge against Dacre is resolved. Prior to that, Evans has skilfully allowed for both Dacre and Laura's reputations to be fully explored before the denouement which discloses upon Laura's scandalous impersonation over her dead sister Beatrice. At this point, Laura's disclosure of her real identity and the sad tale of her sister's death and association with Dacre fulfils the role of the purposely mistaken identity associated with the sensation novel. The presence of a Victorian moralist flavour is thus largely everted until the penultimate chapters, notably in the 'Forgiven' episode, when the suspect Dacre becomes not only Lucy's 'true love', but also an idealised Christian figure whose love must remain 'spiritual'.

\section{Narrative}

In terms of narrative style Over the Hills and Far Away is seen to imitate the 'documentary method' whereby events are related through diaries, letters or journals (Jones 125). The principal source is firstly evident in the use of Lucy's diary during her journey to New Zealand, then followed later on by a more factually driven and linear sequence narrative in the criminal genre (Jones 120). In comparison to the in-depth characterisations and descriptiveness of other 'serious' fiction, the sensation phenomenon as seen in Over the Hills and Far Away brings a more altered reading into perspective, demonstrating an 'expedient' interpretation of character and event. Thus the frequently vacuous and saccharine presentation of Evans' characters (as echoed in

Clinton Meredith's sudden remark over the Lennox sisters' 'regular' and 'horribly insipid' faces) have a banality that serves the underlying purpose of sensation narrative. A further indication of Evans' spare yet telling method of characterisation, is Lucy's 
sudden yet insightful observation of Meredith: 'One foot on shore, and one on sea, to one thing constant never' (OHFA 94).

Among other narrative features to which Evans' novel also adheres, is its essential faithfulness to the conventions of narrative closure usually demanded by the Victorian novel, such as the requiring of a form of 'resolution' or moral outcome through death or marriage (Flint 25). An example occurs in Evans' adaptation of the Collins' treatment of the 'iniquities of marriage' (Pykett 201) as seen in the sub-plot of Laura and Dacre's past entanglement and the suggestion of bigamy in the marriage of Lucy's brother Louis. The role of marriage in Over the Hills as the suggested means of resolution to the plot differs somewhat, however, in Dacre's tragic death and Lucy's forfeiture of the prospect of marriage.

Until the final two chapters, Evans appears to take particular care in maintaining the 'tightly-plotted' suspense plot line in this novel of the 'new mode' of colonial writing (Jones 125). This is seen for example in 'On the Lewes Road' (Chapters 1) and 'Lucy's Diary' (Chapter 3) with the central clue of Laura's letter emerging as the pivotal feature for resolving the theme of the 'hidden relationship'. To begin with, at this point in the novel, the main heroine Lucy is established as the narrator's main focus for the romance theme. At this time Lucy is found surrounded by an emerging cast of characters: her brother Louis, romantic suitor Clinton Meredith, 'hidden' love interest Dr Dacre and the 'mystery' woman crucial to the plot of 'Laura'. In what may appear a prosaic narrative style, Evans nonetheless initiates a series of characters and responses that will be developed more fully to include the subversive features mentioned by Jones i.e. a bigamous relationship and mystery of false identity. In the opening chapters, Evans also conforms to many features of romance melodrama, such as in her attaching of significance to descriptions of dress, making frequent mention of minor accessories such 
as bracelet 'charms', velvet neck ribbons and 'mysterious' physical deformities associated with a secret 'past' (such as the scar on Laura's otherwise beautiful neck) and items of sentiment (i.e. lockets).

\section{Characterisation}

In its overall characterisations Over the Hills and Far Away appears to be rather more influenced by the idyllic recreation of the circle of gentility known at home, what Kirstine Moffat's The Puritan Paradox describes as 'aristocratic pleasure seekers rather than pioneers' (Moffat 19). Early on in the journey to New Zealand, a leisured circle can be seen forming among Lucy's sphere of acquaintance which appears strongly middleclass i.e. army officers, doctors and girls being accompanied out to the colony by their brother. Upon leaving England the facts of shipboard life carry constant reminders of the homeland in Evans' portrayal of shipboard activities. The influence of the Canterbury Settlement and the Anglican Church in New Zealand's early emigrations are a clearly identifiable feature, as witnessed in Chapter 3, in the captain's reading of 'Morning Prayers of the English Church' (OHFA 26). Seen from the vantage point of the ship's deck, Lucy's youthful anticipation of arrivals and future engagements all suggest a smooth transition into the new, waiting social milieu of the colony. For instance, Lucy notes in her diary that a Mr Prior, emigrating to Otago, has relations 'already settled and prospering' (40). With an authorial guiding commentary the Over the Hills' text positions Lucy in the discourse as judge of social appearances and character, fashion and custom; a role clearly illustrated in her observance at a local gathering underlining the following injunction: 'It was an understood thing [in that part of the New Zealand colonies] that ladies were never to appear before a colonial audience in anything but demi-toilet' (143). A similar sentiment is to be found in the following from the author's preface: 'Society has become more formal, and conforms more strictly to the rules in vogue in Europe'. 


\section{Theme}

The novel's title Over the Hills and Far Away thus suggests a place of distance and geographic isolation from the homeland of Britain where scenarios of fulfilment and romantic escapism might be envisaged - not always within the boundaries of social or moral convention. Mr Cunningham's station set among the hills of New Zealand, and only recently made hospitable, presents (to Evans' mainly British or American readers), not only a setting for the visual imagination to roam in, but also an opportunity for a sentimental and melodramatic view of 'paternalism' in the 'transplanted' Victorian family and gender stereotypes (David 98).

In Lucy's diary and later in the third-person narration Evans explores feelings surrounding paternal authority, sometimes taking what might appear a satirical view of the manly 'chivalric' code and models of femininity. In episodes describing flirtation and courtship, the naïve simplicity of a young woman's first steps into what will be a new 'society' in a far away land, takes along with it a world of inherited manners, conventions and social expectations. In accordance with conventional romance plot expectations, Lucy's diary of meetings with male acquaintances on board ship bear the flavour of a romantic fortuitousness. Though at times simplistically delivered in its narrative style, Evans'effectively presents an underlying ingredient of 'suspense'. Evans then colours her narrative by exploiting the gothic romance through an expressive romantic imagery and melodrama. See, for example, chapter 28 , where 'the face' is seen to come forth in its 'strange wild beauty' (OHFA 92).

Collins' fascination with the unstable boundary between the normal and the deviant and power relationships within the Victorian family, as more recently described in texts such as The Cambridge Companion to the Victorian Novel (2001), are incorporated by 
Evans with histrionic flair, in particular with her depictions of outsider figures and paternal authority within settler culture. This is seen for example in the veiled infamy of Laura or 'Mrs Keith' (OHFA) and 'Madame Ainsleigh' (ASF) becoming 'sensationally' exposed by Evans through an intricately worked plot that confronts internal contradictions of the genre with regard to 'normal' and 'deviant' behaviour, sex and gender stereotyping. With her 'pale face and black hair' (OHFA 286), magnificent dresses and 'velvet on her throat', Evans positions Laura (or Mrs Keith), in the sexual female gothic element to which her outsider position decrees (287). As a form of shadow figure, Laura appears to exert a degree of control, yet perhaps in the nature of sensation romance lacks the malefic characteristics of the more serious fiction of Bronte.

\section{Other 'Romantic' Novels}

In Over the Hills and Far Away Evans refers to two other popular romantic novels: The Mill on the Floss by George Eliot and Charlotte Bronte's Jane Eyre (whom the author acknowledges in her 'Preface'). Evans' first serialised novel Guy Eversley (where the 'proud heroine must be blinded before she accepts the virtuous hero') is described in The Oxford History of New Zealand Literature as a 'reversal' to the character of Rochester in Jane Eyre (Jones 125). In Chapter 1 of Over the Hills, in an overlap with fictional realism, Evans creates a "novel within the novel" effect by incorporating Mill on the Floss and Jane Eyre as books to be read on board the 'Flora MacDonald' by Laura, the 'mystery' woman figure. The character of Laura's image as an outsider is further enhanced in Clinton Meredith's aside that she might well have 'a whole novel in three volumes connected with her' (OHFA 76). Further to Jane Eyre the characters Lucy and Dacre appear to play similar roles to that of Edward Rochester and Jane, with each of the novels sharing in common an 'older man with a past' and 'younger' unmarried heroine. In another, re-occurring instance of the female shadow figure, is Bronte's invention of Bertha in Jane Eyre. This is echoed in Dacre's admission that he 
could 'curse the day when I took her [Laura] for my wife' (57). Similar to Jane Eyre is Lucy's reference in Over the Hills and Far Away to the older Dacre as a man with 'shock' and 'trouble' that has 'coloured his whole history' (66). In the denouement of Over the Hills, Evans is also found to be noticeably careful in her drawing out of Dacre's feelings for Lucy, which forms yet another parallel with Bronte's novel in the romantic passion seen in Jane and Rochester's 'resolved' relationship.

\section{Contemporary Pioneer Women Novelists}

Two New Zealand women novelists writing during the same period as Charlotte Evans were Isabella E. Aylmer, author of Distant Homes: Or the Graham Family in New Zealand (1862) (NZETC Collection) and more particularly Lady Mary Anne Barker, whose epistolary memoirs Station Life In New Zealand and Station Amusements in New Zealand are now well established in the early national canon (Jones 123). Aylmer's and Lady Barker's works share certain characteristics in common with Evans, at least in terms of their portrayal of Christian ethic and social relationships found in pioneer society. The novels shed anecdotal insight upon the construction of everyday existence and European settlement in mid- New Zealand: in Aylmer's descriptions of early settlement in Nelson and in Evans' felicitous relating of colonial pastimes, such as the picnic in 'Under the Gums' (Chapter 12) and the 'End of the Concert' (Chapter 14) at which Dacre and Lucy meet. Evans also shares similar themes with Barker's memoirs, as for example in Barker's fictional depictions of social life at a station in early Otago i.e.: 'Everyday Station Life' (Letter 15)); ‘A Christmas Picnic and Other Doings' (Letter 4); and 'Death in our New Home - New Zealand (Letter 9). If in these narratives Evans did in fact attempt to deflect away from any 'dangerous unpleasantness' (Stafford and Williams Introduction: A Land Mild and Bold), they did so by embracing both the pleasures and difficulties and everyday crises and hopes within a discourse of gentility. Subsequently, the question of narrative voice presented an interesting comparison for 
both women authors who were seeking in the nineteenth-century to address in reassuring tones an Empire readership that could then have seemed distant or superior in its demands: an audience made to respond to the 'tone of command truly imperial' (OHFA 98).

Unlike Evans who wrote while domiciled in New Zealand, Barker and Aylmer were at least partially absent from the scenes of their narratives. Barker was distinctly autobiographical, basing her writing on letters written during a period spent in New Zealand. Aylmer, on the other hand, never actually lived in New Zealand. Writing from England and also sharing Evans' Christian background, Aylmer based her novel Distant Hills on letters written by a cousin of her husband's (Moffat 5). In Station Life Barker reconstituted and reflected upon memory while reliving her former New Zealand experiences. Distance and a lack of direct familiarity with New Zealand's geographical and social terrain thus posed their own, sometimes amusing, differences in the realism Aylmer in particular brought to her writing (Moffat 5). Aylmer's portrayal of New Zealand's early settlement appeared as an epic narrative, with moral overtones derived from the influence in the colony of the early missionary church. Distant Homes has since been criticised for its puritanism in The Puritan Paradox (Moffat 5). While the thread of moral didacticism runs through the work of Evans' and Aylmer's works in particular, the vein of religious sentiment in Over the Hills provides a thematic 'crux' for the romantic plot's final resolution. As noted by recent biographers, the results of Aylmer's imagined perceptions of New Zealand have produced their own anomalies in an early pioneer novel that conveys the challenge of writing for a distant Empire audience - of a country situated emotionally and geographically 'far away' (Moffat 5).

Evans' thematic handling of the colonial setting is similar to that of Barker and also another less well-known pioneer novelist Elizabeth Boyd Bayly (NZETC Collection). 
The primarily autobiographical works by Barker relate to the period of her second marriage to Frederick Napier Broom, whom she married in 1865. Many aspects of Barker's own life in fact bear similarities to the plots of Evans' novels, including even a touch of that risqué element associated with the colonial sensation novel. Barker in fact left her children in England to follow Broome out to New Zealand (Barker 12). Like the Cunningham family in Evans' novel Over the Hills and Far Away, Broome intended to buy a sheep station. In common with the Cunningham family's sailing from Brighton to New Zealand on a long sea voyage and prior to their settling in at the station home 'Maungarewa', Barker and her husband were also to brave a 'long, stormy voyage' to Lyttelton Harbour in New Zealand's South Island (Barker 71). The couple then made a laborious trek over the Port Hills of Christchurch. In 1866, the Barkers moved to a sheep station which they named 'Broomielaw' (Barker 109). It was from Broomielaw, situated in the foothills of the Southern Alps, that Barker began a series of correspondence to Britain that would form the basis for her classic autobiographical novels. Barker's biography and literary motivations also find a parallel with those of Evans, in the form of a frontier farming lifestyle and diminishing financial returns, for which the writing of literature could provide additional income.

Climate, sudden upheaval and nature's unpredictable elements feature also in both the fortunes of the Barkers and the Somerset family in Evans' novel A Strange Friendship, whose station home life is disrupted by the sudden rising of flood waters (ASF 203). It was following a 'severe snow storm' that the Barkers made the reluctant decision to return to England, from whence the memories of colonial life provided the impetus for a nostalgic look back to the life they had previously led in the colony 'far away'. Barker's brisk and entertaining approach to her writing recalls with vigour the impressions she received from what was a relatively privileged standpoint. She joined with Evans in her observations of people and the sense of a new energy or independence synonymous with 
the expectations of a 'new' society, in which class divisions could only be a reflection of the more entrenched class system in England. Barker's tone of optimism noting the 'very practical style and tone' and 'independence in bearing' of the people (Barker 10), shares in common with Evans the capturing of a breaking down of usual social and domestic boundaries. The pertinent and more ambitious flavour of domestic servants in comes in particular to the regular observation of Barker and also Evans. In A Strange Friendship, Dolly enthuses on the 'rapidity' of the new strengths learnt by their new domestic servant Lizzie and 'her readiness of resource upon an emergency' (ASF 24 ).

Elizabeth Boyd-Bayly (A New Zealand Courtship and Other Work-A-Day Stories) (NZETC Collection) also concerns herself with patterns of courtship and popular romance conventions set in the colony - except this time in a strongly working class context. In A New Zealand Courtship published by the Religious Tract Society of London, Boyd Bayly traced the progress of 'honour' in romantic courtship between John and Sallie, a working class couple, two Sunday School teachers in the rural settlement of Rakawahi. In Chapter 2, John and Sallie's story is drawn against a setting of rusticism and visual degradation as the courting couple earn local acceptance through their moral commitment to a lengthy engagement, validated in the comment that they 'never had done anything on the sly'(60). This romance of the colonial working class occurs during a time of economic depression when 'great men were failing on all sides; but the little men held on their way-married, and wanted houses for themselves and their stock' (65). More than Evans, however, Bayly exploited the features of natural landscape to create a sense of hybrid New Zealand romanticism, evoking in the moving and shifting shades of 'dark and purple' and 'fitful gleams of sunshine', the impressions of lowland plains and rivers (10). In another attempt at romanticisation of the New Zealand landscape, Bayly saw familiar landmarks such as the Port Hills of Christchurch as 'cumulus cloud, like vast heaps of snow resting on their own grey shadow' (10). A 
colonial gothic then looms at the edge of the 'little settlement of Rakawahi' in a 'wilderness of Maori-heads' (10). In their subjection to the vagaries of the New Zealand climate, the rural livelihood of Bayly's farm characters have something in common with the home of the Somersets in A Strange Friendship, being ever threatened by floodwaters. As Bayly's character states: 'When it does not rain outright in that part of New Zealand, it shines; and when it rains, it 'pays attention to it' (12). More than Evans, Bayly's narrative descriptions portray the strenuousness of a physical pioneering life, marked by a local terrain of 'thick stumps of peaty earth, two or three feet high, each bearing a crown of long, coarse, drooping grass, like unkempt hair' (12). In Bayly's hungry, survivalist version of the colonist milieu 'the stumps are like peat; the people cut them, and use them for fuel. The soil, when cleared, is rich in the extreme' (12).

\section{Conclusion}

In comparison with her New Zealand contemporaries, Evans had a relatively prolific output for an isolated writer, having two published hard-back novels, three published short stories and a small collection of poetry to her credit. Evans combines the influences of literary genre with elements of her own biography to offer an early, yet hybrid, version of a New Zealand novel. As a sensation novelist, Evans explores the breaking of accepted moral codes and social norms by writing of gender relationships and the position of women in marriage. Although working within the framework of light romance fiction, Evans manages to suggest a sense of human character and its consequences, in particular the plight of women, en route to fortune and happiness. Her novel themes include the rituals of romantic courtship and the colonists' all-important task of acquiring property, wealth and at times even a landed title (readily seen in her extended kinship link with the Ogilvie-Grant family) (ATL-MS-5135-03). 
As a work of early Empire writing, Over the Hills and Far Away is concerned mainly with adventure and relationship, finding its own place within the everyday world of social identity filled with passing needs and day dreams. Such a story might have been intended not only for the Empire reader, but even more perhaps, for the actual shipboard passenger on a long sea journey to the colonies. In her novel of epiphanies and felicities, double entendre, attractive men and picture box pretty women (including the ineffable prettiness of young Jeanie Lennox) Evans creates a book of entertainment wherein 'dreams' might become 'reality', yet not without some human ordeal. In this novel is the central character of Lucy, who with her pleasing though not stunning features resembles the heroine of Jane Eyre. For Lucy has at least one salient attribute - her hair of 'lovely curly rings, clustered full of golden lights ...' (OHFA 3). As a novel both quixotically sentimental and a reminder of new beginnings, contained within the boundaries of inherited convention - yet indefinably 'other' - Over the Hills and Far Away presents an early glimpse of a 'story of New Zealand' 


\section{A STRANGE FRIENDSHIP:}

A STORY OF NEW ZEALAND.

BY C. EVANS.

LONDON :

SAMPSON LOW, MARSTON, LOW, \& SEARLE, Crow bUildings, 188, Fleet street.

DUNEDIN : REITH \& WILKIE.

1874.

[All rights reserved.] 


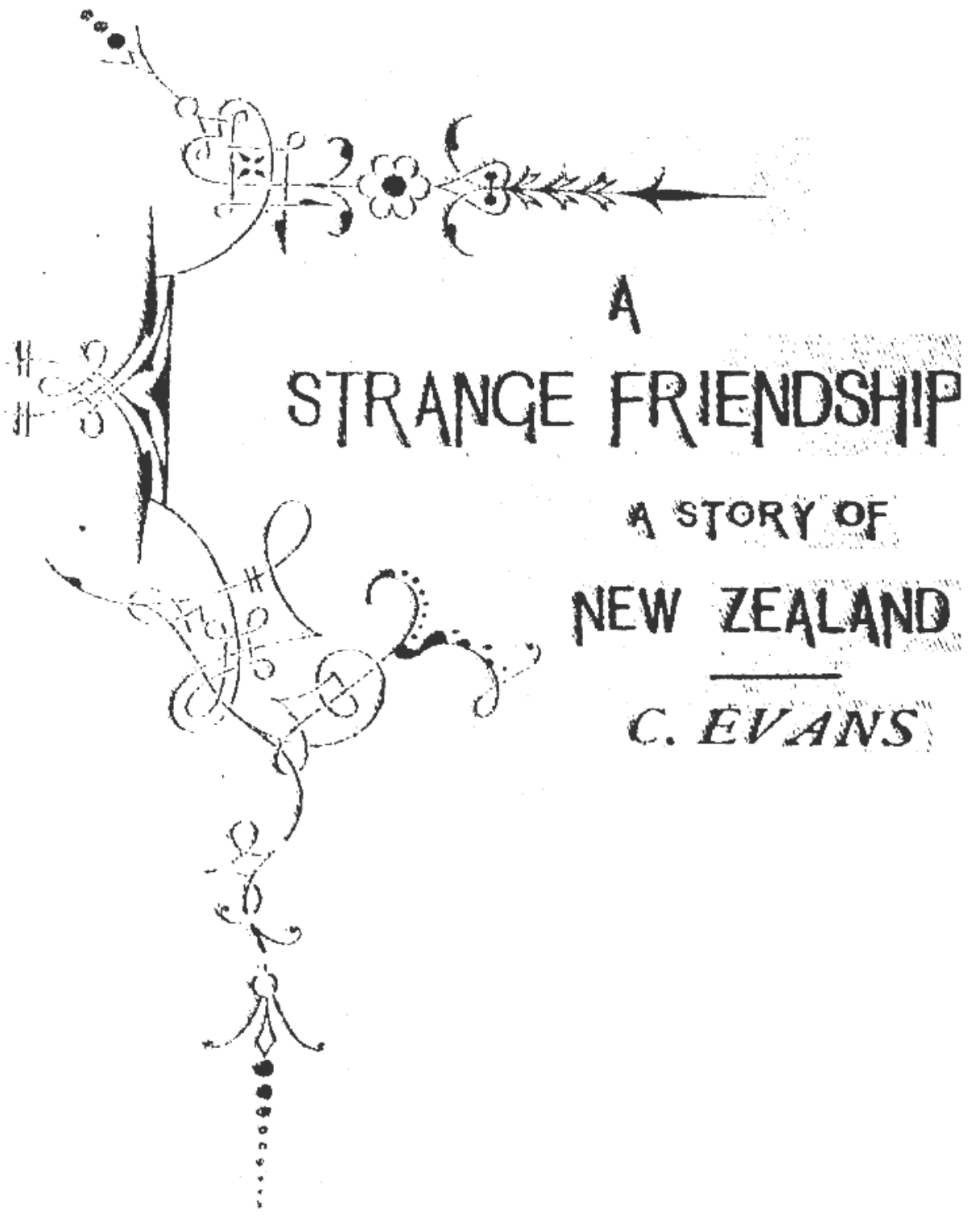




\section{A Strange Friendship}

\section{Introduction}

A Strange Friendship: A Story of New Zealand (1874) was the second novel written by Charlotte Evans. The novel has the same sub-title as Evans' first novel Over the Hills and Far Away: A Story of New Zealand (1874) indicating that the stories were intended to evoke a story of Empire romance set in a distant and exotic place. A Strange Friendship was written at the suggestion of Evans' publisher Sampson Low, Marston, Low \& Searle following the firm's earlier acceptance of Evans' story Over the Hills. The novel also differed from its predecessor through its joint publication in New Zealand with the Dunedin firm Reith Wilkie. A Strange Friendship is somewhat shorter in length than Over the Hills having twenty-six chapters. Evans' storyline revolves around two principal narrators, 'Dolly' (Dorothea Somerset) and 'Alan' ('Alan Ainsleigh' alias 'Alan Carewe'). The plot of A Strange Friendship concerns the mutual progress of the Somerset and Ainsleigh families in New Zealand who are neighbours living in the same district. Unbeknown to the Somersets, the Ainsleighs (Alan and his sister Madelaine) exist in a state of subterfuge, adopting a mode of living in lesser surroundings due to the need for secrecy.

\section{Reviews}

In the year of its publication, 1874, A Strange Friendship received reviews in the Otago Guardian and North Otago Times newspapers. Another (undated) review for both A Strange Friendship and Over the Hills and Far Away appeared in the North Otago 
Times. The Otago Guardian review is brief, acknowledging Evans' role in the burgeoning field of colonial literature. New Zealand is congratulated on having an 'author capable of writing with such sweetness, power and pathos':
A Strange Friendship
A Story of New Zealand
By C. Evans
London: Sampson Low and Co
Dunedin:

\begin{abstract}
We have read 'A Strange Friendship' thrice, and it seems to acquire fresh beauty on each perusal. We congratulate Mrs Evans on her work, and hope to hear of her again and we congratulate New Zealand on the possession of an author capable of writing with such sweetness, power and pathos. We may add that the 'get-up' of the volume is unexceptional as regards both type and paper and the binding is of a very tasteful and pleasing character. - (Otago Guardian [October 26]:1874).
\end{abstract}

A second and longer review given in the North Otago Times announced Evans as an authoress 'resident in this district', before continuing to offer a more serious consideration of her work, without prejudice to 'locality', based upon her 'intrinsic merits'. Of added mention were 'contemporary reviews' (overseas and in New Zealand) the latter of which raising the first hint of any adverse criticism. With the 'local paper' concerned yet to be cited the review related as follows:

Before reading the book we had had the opportunity of perusing contemporary reviews - 'those of the London 'Times' congratulating the authoress on a genuine success' and of a local paper very much on the principle that a 'prophet hath no honour in his own country'. - (North Otago Times [October 29]: 1874).

In an attempt at impartiality the review went on to be highly complimentary, noting in A Strange Friendship 'very few blemishes of style'. Evans was seen to have 'promise' 
with the potential for taking a 'high place among writers of fiction'. In its analysis of the novel the review drew attention to the 'salient features of the plot', citing Evans' invention of the sensation feature of 'false identity' and Madame Ainsleigh's assumption of the feminine character. A Strange Friendship's plot was considered, nonetheless, to be 'simple' with 'no sensationalism or labyrinth interweaving of byplot' - yet with 'many interesting details'. Finally, readers were persuaded to acquaint themselves further with what the review intended for them as a form of 'pleasure' reading in the light romance genre:

We are persuaded that all who take our advice have a pleasure in store for them, and that they will rise from a perusal of Evans' book with the conviction that the authoress possesses powers of no ordinary calibre, and with the wish to have the opportunity of reading still further productions of her facile pen. - (North Otago Times [October 29]: 1874)

Another (undated) review contrasted A Strange Friendship with its counterpart Over the Hills, offering several thought provoking observations, the first of which being that the plots of Evans' novels were not necessarily situated in the colony itself, or even hinged 'upon any peculiar phase of colonial life'. In its second opinion, the review saw Evans' stories as belonging rather more to a class of novel which could bring what was 'peculiarly colonial' into 'relief' (perhaps in a way yet unanticipated):

We have so few books of this class that it still seems strange to read of things which we think nothing of when enacted around us daily, but which at once strike us as being peculiarly colonial when we meet them in the course of an interesting story. - (ATL-MS- Papers-5135-

In raising the viewpoint that Evans' story plot displayed 'no attempt at sensationalism' the review neglected perhaps to acknowledge that it was, after all, 
beginning to report on a new and unfamiliar genre - the popular 'sensation novel'. An appreciation of plot is evident however in the review's clear preference for $A$ Strange Friendship's storyline, thought to be the more 'cleverly conceived' to Over the Hills and with the plot interest more securely 'maintained to the end' (ATL-MSPapers 5135-09). The same review points to a further salient feature of Evans' more condensed version of the sensation novel, differentiating it somewhat from the lengthier descriptiveness of other popular works of the period, including the sensation novels of Wilkie Collins:

There is one thing about both books which will doubtless commend itself to many readers in those days of rapid work, and that is, there is no mere padding, so to speak; and there is therefore no occasion to wade through or jump over tedious parts.- (ATLMS-Papers 5135-09)

\section{Introduction to the Novel}

A Strange Friendship reflects the sensation novel's contemporary concern with social change and the rise and development of the novel form, in particular the 'mid-Victorian sensation novel' (David 193). A Strange Friendship has similar sensation plot features as found in Over the Hills involving a break with social convention and being reflective of 'cultural anxieties' synonymous with the Victorian era (Pykett 196). The novel relates also to the sensation writing of Wilkie Collins (Pykett 193). While Collins' contemporary, the novelist Charles Dickens, explored some of the inequalities inherent in Victorian society, Collins' text identified with shifting social boundaries, false identity and criminality (Jones 120). In A Strange Friendship Evans related to a middleclass desire for material and social prosperity in the romantic themes of desire and choice of marriage partner. However, in her exposure of one of the novel's central characters Violet Somerset, Evans also allowed for the idea of a female sexuality that was both out of control and transposed simultaneously into the colonial context. The 
marriage plot then concurs with the destabilising effect of female subversiveness (in the form of Violet's elopement) which in turn becomes a threat to the economic order of a prosperous colony.

In their mention of contemporary fiction within the narrative, each of the novels Over the Hills and Far Away and A Strange Friendship appear to deploy the "novel within the novel' effect. As an example, in Chapter 2 of Over the Hills, Clinton Meredith exhorts to his fellow passenger the value and importance of reading current novels that were then 'fashionable' (i.e, Jane Eyre and Mill on the Floss). In A Strange Friendship is Alan Ainsleigh's suggestion for Dolly (whose full name 'Dorothea' incidentally also corresponds to the main character in 'Middlemarch) to read the novel 'Middlemarch', along with tales from Arthurian literature (Chapter 1). As the people at the Somerset home faced their future settlement prospects in the colonies, the themes in the stories may have possessed underlying portents for the protagonists to consider, with the shipboard passengers being intended to benefit from their warnings or provisos. There could also be more than just a hint of satire in Alan Ainsleigh's choice, as a colonist, of the 'The Holy Grail'.

Like George Eliot's Middlemarch, Evans' A Strange Friendship is a study of middleclass provincial life, this time set in the colonies. As colonists the characters in Evans' novel are primarily concerned with re-establishing themselves, both socially and materially, along familiar lines to that which they have recently left behind in the counties of England's Sussex. However it soon becomes evident that emigration to the colonies has its risqué element; in the uncertain tides of fortune which could assail the new settlers and the new families or neighbours encountered in the colony with secretive pasts. In A Strange Friendship this occurs in the Somerset's negotiation of neighbourliness with the Ainsleighs, whose suitability as family acquaintances 
undergoes several reviews, in particular by Violet Somerset's elder sister Dolly. Thus the uncertainties of relationship in Evans' escapist version of colonial emigration could be said to share certain characteristics in common with Eliot's novel of English provincialism, as both novel plots reflect the shifting social boundaries of British industrialisation and the Empire period.

\section{Plot Features}

Evans' exploitation of plot in the sensation genre emphasises certain features mentioned by Lawrence Jones in the Oxford History of New Zealand Literature in English, for example, the crimes and secret past separating hero and heroine, and an emphasis on the 'unravelling of a mystery' and use of false identity (Jones 125). The narrative techniques used by Wilkie Collins also feature a preoccupation with mistaken or 'false identity' involving detective work (Jones 125), all of which relate to the plot in $A$ Strange Friendship. Foremost in the underlying plot of A Strange Friendship is the marriage contract and the hope of an eventual marriage for Harry's two sisters each living in a colonial social milieu of bachelors. This was a situation not inconsistent with the landed provincial gentry back in England, but complicated further in A Strange Friendship by gender disguise and subterfuge. Similar to Over the Hills and Far Away the future destinies of several of the characters are occluded by past misdemeanors with their solution remaining dependent upon the outworking of a romance plot. Within $A$ Strange Friendship can thus be seen two interweaving plot themes; the 'strange friendship' between Violet Somerset and 'Madelaine' Ainsleigh (alias Richard Carewe) and their elopement to Australia - and the 'hidden romance' theme of Alan's attraction to Dolly and desire for an engagement. Two further sub-plots also emerge in the uncovering of Madelaine's disguise and the restoration of the Carewe estate 'Curtis Knowle'. However also serving these plot elements are the plot devices of clues, letters and a series of criminal investigations coincident with the conventions of sensation 
narrative. Throughout A Strange Friendship Evans constructs an intricate thread of suspense within a discourse of the light popular fiction genre.

A Strange Friendship's structural divisions can be divided into three main sections: 'Dolly's Story' (Chapters 1-3, 6-8, 10-17) concerning the introduction to the Somerset family and emigration to New Zealand and the sister's new acquaintance with the Ainsleighs; 'Alan's story' (Chapters 4-5, 9 and 18) relating to his meeting with the Somersets, his first impressions of Dolly and Violet and departure for Auckland. This is followed by his confession to Dolly. In Chapters 19-26, concern over Violet's disappearance accelerates the dramatic and mystery suspense plot elements and considers the effect Violet's disappearance is having on the Somerset family. This development is accompanied by Hugh Maberley and Alan Ainsleigh's departures for Australia. Violet then returns to New Zealand followed by Richard Carewe (formerly 'Madelaine Ainsleigh's') with tragic consequences. The deaths of the eloped couple back in New Zealand then allow Alan and Dolly to marry as inheritors of 'Curtis Knowle'.

A Strange Friendship is related in the first person alternately by two of the principal characters, 'Dolly' (Dorothea Somerset) and 'Alan' ('Alan Ainsleigh' alias Alan Carewe), as they describe the mutual progress of the Somerset and Ainsleigh families in New Zealand who are neighbours living in the same district. Recently emigrated to New Zealand, the Somerset sisters are said not to have begun life advantageously, having been orphaned ('we had only each other and Harry') at an early age (3). In the beginning chapter, the narrative voice is Dolly's, reflecting upon early events in England prior to departure for New Zealand when the sisters lived in a grange in Sussex and were bridesmaids at their brother's wedding. Dolly's tone of nostalgia draws heavily upon a period during which she and younger sister Violet were close and as yet 
unaffected by the unsettling misfortune of their first years in the colony. Violet's portrait is drawn in 'retrospect', as Dolly recalls her 'bewildering vision of beauty, with forgetme-nots in her hair the colour of her eyes' (3). However, during the journey out to New Zealand, signs are already beginning to show that Violet's lively temperament could persuade her into precipitous liaisons; the first being a 'young fellow-passenger' dying of consumption. Very little is mentioned of the voyage out to the colonies, described by Dolly in carefree, pleasant terms, before the young family commences the task of settling into the new homestead. This early, formative period in the family's settlement, involving hitherto unrealised adaptations to practical realities ('there was so much work to be done, and we knew so little how to do it' (7)), represents a phase of close domestic cooperation between the two sisters, their step-mother, brother and a new baby. The introduction of a new Scottish servant Lizzie to the household in Chapter 8, brings mention of working class attitudes in the colony, in contrast to the gentility of the Somersets. However, Dolly is quick to enthuse over the effect colonial life can have even on domestic servants, with the 'rapidity' of the new strengths learnt by Lizzie and 'her readiness of resource upon an emergency' (24).

From the very beginning of the novel, the mutual acquaintanceship of the new neighbouring families forms the main preoccupation of the narrative. As the sisters become more deeply involved with Alan and his 'sister' Madelaine, the position of Harry Somerset as the central male figure in the Somerset household assumes its own dominance over the family's practical survival; the family homestead being situated in an unfamiliar terrain wherein 'creeks will sometimes rise in a few hours' (25). Even more than the Somersets, the Ainsleighs appear to be of the 'gentlemanly' class, yet their appearance and conduct are still subject to close scrutiny, in particular by Dolly, as younger sister Violet becomes increasingly infatuated with Madelaine. What has yet to be discovered, however, is the fact that Madelaine is not a woman at all, but a man in 
disguise with the real name of 'Richard Carewe', Alan's step-brother. While rounds of introduction continue Madelaine's 'stranger than strange' friendship (suggested in the story's title) with Violet maintains its outward semblance of normality; the only hint of masculinity being Madelaine's extra-firm handshake and strikingly independent nature. In addition to the Somerset's circle of acquaintance is the entering into their lives of Hugh Maberley, another bachelor of the district, who is inexorably drawn to the blushing Violet yet remains hopefully at the periphery of her affections. A major turning point in the plot occurs in Violet's sudden and mysterious disappearance which then precipitates a series of incidents (including the unsolved death of a man in a nearby creek) during which clues are uncovered pointing to the nature of Violet's fate. While the Somerset home is in turmoil the male characters, including Violet's friend Madelaine, are seen to move in and out of the storyline, travelling over to Australia in search of the missing heroine and, in Alan's case, to solve his family and inheritance problems.

\section{Characterisation}

The main characters in A Strange Friendship are the Somerset family of two sisters, Dorothea ('Dolly') and her younger sister Violet, their elder brother Harry Somerset and his new wife Kate. Through their marriage which takes place in the first Chapter, Kate and Harry replicate the earlier absent patriarchal family, while out in the colony the younger women Dolly and Violet assume the role of nurturers as well as being eligible for forming their own marriage partnerships. While Dolly is 'plain' and conventional (246), Violet is a source of concern with an impulsive nature that might suddenly threaten to transgress moral safety. Both sisters are concerned with the prospect of marriage in a colonial society of male frontier culture, a society of bachelors, of expansive landscapes where distance and population define the social milieu. Evans thus 
forms her characters around the social realities of the colonial frontier; a place of increased neighbourliness and new freedoms yet still guided by a Victorian paternalism.

The family with whom the Somersets become involved in the colony comprise Alan Ainsleigh and his sister Madelaine. Other minor characters in the story's plot are Hugh Maberley (a local bachelor) and Lizzie the Somerset's house servant. Each of the female characters have distinct personal characteristics and emerge through the observation principally of Dolly and also Alan Ainsleigh, whose points of view both dominate the plot. The demure and 'naturally shy' Dolly, modelled after a Quaker sister of her mother's whom she also 'resembles in placidity of disposition' (7) appears to assume the role of protectress toward her younger, prettier sister Violet. Dolly is seen by Alan Ainsleigh as 'sweetness and light' with a 'certain honesty of expression' (48). The two sisters, having grown up with only an older brother, are in effect orphans. They are also often depicted as caregivers or nurturers for the new Somerset family. Although presented as two stereotypical female figures with strong dependent family ties, Dolly and Violet are paradoxically estranged from normal family relations, having a somewhat mysterious upbringing with a mother 'dead so long [then] we could only recall her as a fair memory of our childhood' (3) and a father having been gone Dolly remembers since she was 'quite baby (3). Violet appears early on in the story as a lively, capricious, rather spoilt female character poised to instigate the upheaval in circumstances that will propel the romance plot. Her appearance is her most striking characteristic. She is first described by Dolly as 'a bewildering vision of beauty, with forget-me-nots in her hair the colour of her eyes' (3). She then emerges more strongly in Chapter 3 as being somewhat independently minded and impetuous and also rather vain. According to Dolly, Violet's attention to dress and appearance predominate in her outward concerns. 
The other members of the Somerset family, Harry and Kate appear to be practical and ordinary in appearance. Kate, says Dolly, is nonetheless occasionally inclined to a 'temper' (7). Harry is said to be 'fair, thin and very good tempered' (29). He doesn't appear to be noticeably patriarchal but only prone to a little 'masculine judgment' (80). The Somerset family thus represents an ideal kind of settler family; a class of people with some financial means and will to work and build a new life in the colony. The Ainsleighs, on the other hand, represent a sensationalised form of exiled aristocracy - a more rare occurrence among settlers - involving family inheritance or escape from previous misdemeanors. Alan Ainsleigh therefore appears more complex, typifying the romance and sensation plot's character with a 'past'. His opinions which feature strongly in the narrative are primarily concerned with his need for a secretive life, wherein his real name, social status and liveliehood, are subsumed beneath a state of exile. Alan is described by Dolly as having an 'air of patrician grace' with the easy manners of the upper class (35). However the interior of his homestead 'Fernyhurst' indicating a state of gentility, has many ambiguities, being in Dolly's eyes 'a strange and careless medley of elegance and coarseness' (35). Alan could be described as the troubled 'aristocratic' type with his step-brother Richard Carewe (also 'Madelaine') presented as the foil for Alan's self-image and moral and social restitution.

As a pivotal character, Alan's "sister" Madelaine presents the main crux of his problematic existence and is probably also the most fascinating and extreme character in the novel. The persona Madelaine, or 'Madame Ainsleigh', is in fact a blatant invention of a trans-gendered character, living under a female disguise to hide a criminal past. How the other characters in the story, notably the Somersets, respond to this 'unusual' woman is evident in their inability to fully accept the Ainsleighs into their circle without some hesitation. As a somewhat 'camp' impersonator Madelaine has touches of the bizarre, but, in the earlier chapters with Alan at 'Fernyhurst', is nonetheless presented in 
the guise of a plausible female character. In many ways Madelaine is the least real of Evans' characters, seeming more as an invention for the sake of the text. However, in her 'transformed' self as Richard Carewe, she fulfils her double role as both impersonator and plot villanness. On the surface Madelaine exhibits most necessary female characteristics. She has a taste for expensive Parisian couture, but her hair, worn in a 'chignon', also features a 'false plait' hiding shorter, curly hair and she has a strange tendency to 'whistling' (60).

In her depiction of the principle female characters Dolly, Violet and Kate Evans appears to conform in general to a sentimentalised and 'saccharine' version of Victorian and romance conventions, with much discussion over physical appearance and its denoting of character. Evans also uses the separate dispositions of the sisters to present a moral perspective over vice and virtue and the getting of material fortune; a dream, observes Dolly, Violet adheres to most particularly. Violet also likes to imagine herself indulging Dolly once she has made a home with a wealthy husband. Hence, appearances, the dress code and leisured activities of "privilege". Books and horses dominate the sisters' lives. Like Bronte's heroine in Jane Eyre, Dolly's plain appearance is seen to attract Alan's admiration in preference to Violet, whose pretty liveliness is considered untrustworthy. Thus Dolly's lack of physical vanity, modesty and discerning nature eventually fulfills the destiny of the virtuous Victorian heroine; that of happiness in marriage to a wealthy man.

\section{Narrative}

Having characteristics of the sensation novel in its narrative style, A Strange Friendship could be compared with Collin's The Woman in White, though as a more condensed and lightweight version of the same idiom. Like Collin's novel, A Strange Friendship is multi-perspective, told from alternating points of view chapter by chapter ('Alan's story 
and 'Dolly's Story' vis a vis The Woman in White's 'First Epoch' narrated by Walter Hartright and 'Second Epoch' narrated by Marian Halcombe) with a similar emphasis on sentimentalism, and reflection, particularly in its drawing of character and a factual description of place and event. The sensation feature of letter writing occurs in Chapter 18 in 'Alan's Story' and in the mention of letters from home in Chapter 4. Similarly, in Chapter 8, letters from Madelaine are mentioned by Dolly in relation to the mystery plot and again in Chapter 19, in Dolly's reference to 'English letters' now being too expensive (187). Whereas in Collins the crime story is told by several people and not the authorial narrator, the criminal suspense in A Strange Friendship is relayed via only two persons (Alan Ainsleigh and Dolly Somerset). However, each of the novels shares in common the narrative voice of the characters, speaking in a tone of recollection and nostalgia.

In its chapter format A Strange Friendship also differs from its counterpart, Over the Hills, whose chapters rely more strongly on diaries and an authorial narrator. Like Collins, the reporting narrative in A Strange Friendship is concerned with the uncovering of the 'mystery' sub-plot of Violet's disappearance as, for example, in Chapters 10 and 11 where Dolly relates the sequence of events surrounding Violet's departure. Here the tone of documentary style or re-telling of incident is similarly constructed to that of Collins' manner of using the authorial voice of the 'witness' (as for example in Chapter 1 of The Woman in White, wherein Walter Hartright being 'more closely connected than others with the incidents to be recorded', is asked to 'describe them in his own person' (1). Also featuring in the documentary style uncovering of the disappearance mystery is the criminal, or investigative, narrative of Chapters 10 and 11, where Dolly recalls 'the strange sensation' of holding 'a part of a letter written by Violet herself' (134). 
In A Strange Friendship the points of view of Dolly Somerset and Alan Ainsleigh predominate. The central narrative voice in 'Dolly's Story' is characterised by concerns over social relationships and affective ties between the characters in addition to the recreation of gentility in the colonial homestead. Dolly comments frequently on appearance and behaviour drawing attention to descriptions of dress, objects, domestic interiors often casting a discerning eye over the family's new neighbours the Ainsleighs. In Chapter 1, upon first meeting with Alan Ainsleigh, she remarks that he was 'a man of the medium height, rather dark and brown, and broad-shouldered, with close-cropped hair, and with the air of a person much more used to society than any one whose acquaintance we had yet made (10). Later, she reinforces her initial impressions with a description of Ainsleigh's leisured manners in a home full of apparent contradictions, in which a 'luxurious easy chair by the fireplace was the only handsome piece of furniture in the room, and evidently the seat of honour' (34). Dolly and Kate also engage in a mutual Austen-like banter, for example in Kate's remark over Alan and sister 'Madelaine': 'Mr Ainsleigh seems a thorough gentleman, but his sister is not a thorough lady' (30). In general Dolly writes of her own family, the Somersets, in fond terms, while her view of Violet is a mixture of regret and joy in her sister's lively attractiveness. Alan's narrative voice on the other hand dwells on the frustrations of exile under an assumed disguise, and the prospect of ever attaining to the kind of personal and business respectability he also needs in order to win the hand of Dolly. His letter to Dolly is a confessional of past disgrace and misfortune and need for personal restitution. In Chapter 4 he laments, like the romantic hero, to himself on his 'utter dead weariness' and 'blank darkness within and without' (43). Like the voice of Dolly, Alan in a state of melancholia is also affected by loss, hope and regret, yet at other times (as in the resolution Chapter 26), the optimism characteristic to the colony is able to prevail. 
The presence of gothic and romantic elements in A Strange Friendship also share similarities with Over the Hills, particularly in the use of 'domestic gothic'. In Chapter 21, Dolly observes through candlelight the 'deep hollows' beneath the once vivacious Violet's eyes and her transformation into a 'faded ghost of the past' (208), while her use of pictorialism in A Strange Friendship is less evident that in Over the Hill's. A use of romanticism can be seen appearing in descriptions of the mountain scenery (i.e. 'clothed in the winter in raiment of dazzling snow' (26) and the lurking dangers of the terrain on which the Somerset house is built, with its 'creeks [that] will sometimes rise in a few hours in a manner startling and unexpected' (25) - thereby creating the foreground for the novel's later plot development of the flood which claims the lives of the villain Richard Carewe. Overall in the novel Maori are barely represented, existing as a convenient exoticism at the periphery of the settlers' lives. They are mentioned briefly in Chapter 2 as being able to recollect earlier times -when 'the water had flowed up' closer to the house (25) - and could be associated with a romantic unpredictability relating to natural elements in the novel.

\section{Conclusion}

As the other of Evans' two sensation novels A Strange Friendship appears primarily concerned with the interiority of the characters, in relation to the sequence of events, and with less emphasis on the pictorial qualities evident in Over the Hills. What arouses the reader's attention is the predicament of Violet and the 'strange' nature of her relationship with Madelaine, who unlike Laura in Over the Hills embodies a complete sexual disguise, not just that of name impersonation. In her contrasting of Violet's physicality and lively impetuosity against Dolly's plain 'little quakeress' (57), Evans also highlights two gender stereotypes, wherein the prettier woman is more likely to be seen as dissolute or fickle in nature, thereby ringing up the villain. Even the harsher realities of colonial living appear contained within a saccharine coating of euphemistic 
descriptiveness. Thus A Strange Friendship fulfils the purpose of light, sentimental, fiction by presenting romance and human feelings more as a stylisation of actual life spiced with realism. Through use of first person and the alternating narrative voices of Dolly and Alan, Evans stands back, momentarily, to allow her readers into a more direct personal experience. There is thus a certain equality in Dolly's demure yet independent reactions. Within the pages of this ephemeral light popular novel life and experience assume a vacariousness which, unlike Dickens, presents human character and life in the colony more as a pastiche of itself than society's realistic portrait. 


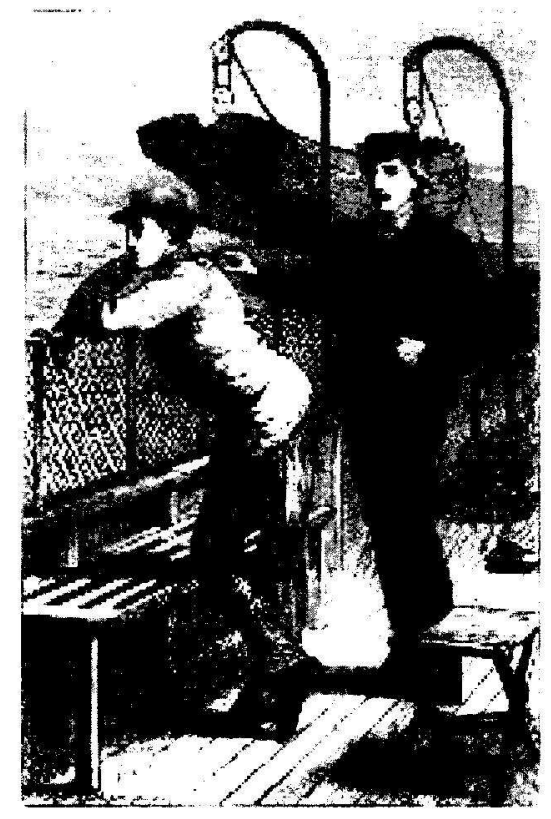




\section{Charlotte Evans: Literary Biography}

\section{Introduction}

\section{Part I}

Charlotte Evans is among the earliest of New Zealand's romantic novelists and a writer of popular romantic melodrama belonging to the 'Pioneer Period' of 1861-1889 in what is termed the 'sensation' genre (Jones 120). Evans was born in Lancashire, England, on 21 September 1841 and died in New Zealand on 22 July 1882 at the age of 40 years. Her full collection of published works included three novels, of which the first, a story entitled Guy Eversley, was serialised in the North Otago Times and Waitaki Reporter in 1865-66. This publication was then followed in 1874 by two novels: Over the Hills and Far Away: A Story of New Zealand and A Strange Friendship: A Story of New Zealand. Evans also produced three short stories: A Narrow Escape, Only a Woman's Hair and Our Nearest Neighbour that were published posthumously in 1900 and 1903 by a London publication called The Family Herald. A selection of Evans' poetry, also collected posthumously, was eventually published by her husband, Eyre Evans, in 1917. It is largely unknown, however, as to what extent Evans' novels were read either in New Zealand or overseas. Copies of the first editions of her published works are now held in the National Library of New Zealand and Oamaru Public Library collections, in addition to a miscellaneous collection of prose and poetry entitled 'Fragments of Poetry and Prose' (ATL-MS-Papers-4426). Evans' two major works, the novels Over the Hills and Far Away and A Strange Friendship were both published in 1874, in hardback, by the 
international London-based firm Sampson Low, Marston, Low \& Searle. As one of the nineteenth-century's more prolific publishers of popular fiction, Sampson Low contributed significantly to the transnational world of Empire readership to which Evans belonged. Other authors published by Sampson Low included her contemporaries: American popular writers Harriet Beecher Stowe and Louisa May Alcott and the wellknown British sensation writer Wilkie Collins. As versions of sensation narrative Evans' novels have been recognised in The Oxford Companion to New Zealand Literature as 'tightly plotted', incorporating the 'sensation' features of 'crimes and secret past' and a 'violation of Victorian sexual mores' (adultery bigamy, and illegitimacy) (Jones 125)). Other recognisable elements of sensation writing at the time included an 'emphasis on the unravelling of a mystery' that turned on 'substitution and false identity)' (125) involving detective work and 'documentary' method (i.e. telling the story in 'partial perspectives of letters' (125). Prior to the full denouement of events would be a 'crucial pocket of time' accompanied by the 'effects of shock and surprise' (125). As a novelist Evans' own reading would appear, like many women of the Victorian period, to have included the work of Charlotte Bronte, whom she refers to in her 'Preface' for Over the Hills and Far Away.

In terms of her biographical profile, Evans constitutes a degree of 'invisibility', having left little or no evidence behind in the form of extant diaries or correspondence. Without further biographical evidence, Evans' personality therefore remains somewhat obscure. Instead, like her novels, she can be viewed at a distance: firstly, as daughter and sister, wife and mother, and perhaps somewhat 'inadvertently' as published novelist. Evans is said to have had a 'committed Evangelical Anglican faith that shaped her life and her fiction' (Moffatt 19). Her religious faith was a facet of Evans' life well illustrated in the slim volume of posthumously published poetry entitled Poetic Gems of Sacred Thought. Her husband, Eyre, was an Irish protestant from Kilmallock, County Limerick. Like 
many 'gentleman' emigrants Eyre first arrived in New Zealand to take up farming, which in his case lay in the district of Teaneraki, or Enfield, some miles distant from Oamaru township. Eyre was also a noted newspaper columnist on the subject of 'Temperance'.

Further insight into the life of the extended Evans family may be gleaned from extant Lees and Evans' correspondence; in particular the letters of Alice Lees Evans, the wife of Evans' elder brother James, whose early death in 1877 Evans is said to have felt keenly (Skillbeck Jottings of a Gentleman 88). More recently, the publication of Jottings of a Gentleman (1997) has provided valuable reference to Evans' years in Oamaru, using her husband Eyre's own words from his diaries and notebooks. These have included private glimpses of Charlotte, her life in the early settlement frontier, and its specifically shared values of mutual support. A consideration of Evans' personality and literary works thus incorporates a consideration of her social milieu and domicile of Oamaru, its burgeoning print culture and her own network of kinship.

\section{The Lees of Lancashire}

Evans emigrated to New Zealand in 1864 and came from a middle-class family. Her parents James and Sophia Lees (nee Ball) had four children, two boys and two girls, of whom Charlotte was youngest. A descendant writes that the Evans children were gifted and well educated, each of them displaying individually a love for painting, music, inventing and for Evans particularly, a natural propensity for trying her hand at poetry and stories (ATL-MS-Papers13-19-1). The Lees family appear to have been close-knit, with a tradition of having had affectionate nicknames dating back to the mid-1700's (Skillbeck 65). The Lees originated from Clarkesfield, an area situated in the district of Oldham, an industrialising area of Lancashire in the north of England where James Lees owned a 'sizeable' cotton mill (65). James disliked the trend in slave labour, however, 
and in the early 1860's sold his business to move further south to Devon where the family lived in the vicinity of Richmond and East Dean (ATL-MS Papers -13-19-1). Evans spent the memorable times of her later girlhood there, enjoying 'a number of short holidays and staying with friends and relations in places such as 'Windsor, Plymouth, Bath, Dawlish, Brighton and even Paris' (ATL-MS-Papers-13-19-1). She thus became familiar with some of the better known landmarks of Devon and Sussex, in particular Plymouth and Dawlish Bay, both of which are mentioned in her novel Over the Hills and Far Away.

\section{Emigration}

In 1864 Charlotte's parents decided to emigrate to New Zealand. James Lees' plan was to invest in land out in the colonies in the belief that 'farming would be the basis of New Zealand's future prosperity' (Skillbeck 65). He was then 59 years of age. The Lees' two sons Joseph and James had already travelled out ahead of them to settle in Otago. In July of 1864 the remaining family of James Snr, his wife Sophia and younger daughter Charlotte, set sail from England on the passenger ship 'Chile', arriving in the South Island of New Zealand at Port Chalmers on 17 November (64).

Oamaru township was consisted entirely of wooden houses and lying on the side of a high hill facing us as we stood at anchor (55).

The Lees' first experience of life in New Zealand took place over the months of early summer. With capital to invest, James and his sons had been engaged prior to emigrating in purchasing property in the district of 'Teaneraki', an area of land located several miles out of Oamaru's township and situated 'in a beautiful valley sheltered between ranges of hills and watered by the Waiareka Creek' (See Appendix I) (69)). The Lees' station home - named 'Teaneraki House' - was among a group of adjoining properties belonging to the 'Teaneraki Estate' comprising the Lees family and their network of relations. These included Charlotte's cousin Edward who lived at 
'Matapuna' - a station-home 'easily visible to the north of 'Teaneraki House' (64).

Each of Charlotte's two brothers settled at Teaneraki; namely Joseph, married to Edith Frost, and James, who married his cousin Alice Lees and settled at 'Alverton' (ATL MS-5135-09). Some time later Charlotte and her husband Eyre Evans were to live on a property belonging to Teaneraki Estate called 'Friston'. The Lees were later joined in New Zealand by their eldest daughter Sophia who had married Charles Gifford-Moore in Cornwall in 1858 (Skillbeck 64). The experience the Lees had in the cotton industry appears to have fitted them well for establishing another enterprise in the Oamaru district under the name 'Lees-Moore', a flour milling business owned jointly in partnership with Gifford-Moore (by then a resident in Oamaru (See Appendix I)). Gifford-Moore became prominent as District Engineer and Surveyor for Oamaru, while Evans' elder brother, James, gained influence as an inventor of barbed wire fencing which he then developed into a local business (89). Family enterprise contributed to the district's progress well into the late 1870's, as the Mill, followed by the building of a school and railway, is said to have owed much to the Lees' family's 'generous planning and action' (67).

\section{Three Closely Linked Emigrating Families}

Trevor Corry (Evans) and I were the advance party, when in 1866 we set sail in the Queen Bee to begin a new life in the colonies. - Eyre (Skillbeck 3)

The Lees' emigration to the colony was intricately linked to that of two other kinship influences; notably the Evans' of Ireland and the Ogilvie-Grants of Scotland (ATL-MSPapers13-19-1). The Evans and Ogilvie-Grants formed a connection with landed gentry and aristocratic title significant to Evans' novel A Strange Friendship and that of earlier departure by an advance party in Over the Hills and Far Away; an emigration pattern 
more immediately attributable to Charlotte's future husband Eyre Evans. Born Eyre Fitzgeorge Evans on 23 February 1842, Eyre was of Irish landed gentry stock, the eldest son of four children of Major George Evans by Louisa Barbara (nee Corry) (Skillbeck 6). His grandfather Eyre, after whom he was named, was an 'Irish Country Squire' whose home 'Ash Hill Towers' was situated in County Limerick (2). The Evans also held title to the Baronet of Carbery (2). On Eyre's maternal grandmother's side he was related to the 'Halls' of Newry in County Down, whose stately home 'Narrow Water' he spent holidays at during his youth (see Appendix I) (9). Not being heir to the Carbery family title, Eyre's father, George, went instead into the military, where as a training cadet at Sandhurst Military Academy in 1826 he became a contemporary of New Zealand's future Governor Sir George Grey. Eyre's growing up years had been in Newry at which time he attended the Royal School Dungannon, in County Tyrone, before attending Trinity College, Dublin (8).

It was at Trinity College that Eyre met Charles Gifford-Moore (20) and made the acquaintance of James Lees, Charlotte's father (26). As the Lees' sons were already planning to leave for New Zealand 'life in the colonies' soon became a 'constant topic of conversation' (26). The enthusiasm of that meeting, and the plans that followed, initiated a pattern of colonial 'diaspora' that eventually reunited the two families again in South Otago where the Lees had purchased property at 'Teaneraki'. The 'advance party' which had initially taken the form of the Lees brothers, Joseph and James travelling out to New Zealand aboard the 'Motueka' from Gravesend in 1863 (64), was then followed in 1866, when Eyre and his younger brother, Trevor Corry, sailed ahead of their parents and other siblings aboard 'The Queen Bee' (28). On the journey out the brothers 'pretended to be sailors themselves', while Eyre wrote and sketched a record of the shipboard life he experienced in a travel diary (see Appendix I). Among his first 
impressions upon disembarkation at Port Chalmers were the same rolling Otago terrain frequently referred to by Evans in Over the Hills (55).

\section{Marriage}

It was therefore in the area of Oamaru 'out riding one day' amidst the same Otago scenery described for her characters' romantic encounters in Over the Hills, that Charlotte met Eyre Evans (ATL-MS-5135-03). Only recently arrived in the colony Eyre had formed a walking party en route to the Lees' station at Teaneraki (Maori for 'sweet water') some nine miles inland (Skillbeck 58). In his memoirs Eyre mentioned his first sighting of Charlotte, noting that at 'about half-way' they had met 'four swell colonial equestrians'. Those described on horseback were 'Miss Lees (Mrs Moore's sister, Charlotte), Miss Lees (cousin), Joseph Lees (Mrs Moore's brother) and Edward Lees (cousin)' (58). Eyre recalled a 'colonial civility' in the reluctance of each party to recognise the other:

I recognised them at once, and as it turned out afterwards, they thought they knew us too. But the 'mounted swells' and the 'roughs' on foot passed each other in silence! - Eyre (58).

Charlotte and Eyre's acquaintance grew rapidly. Evans was then 24 years of age and had already begun to write in earnest, publishing her first story Guy Eversley in the Oamaru Times and Waitaki Reporter (65). Eyre had skipped his final exams as a theology student at Trinity College to travel to New Zealand. He was restless, energetic and enjoying the novelty of station life. From the Evans' station home 'Cloon Eavin' he rode frequently over to 'Teaneraki House' finding the Lees 'fun' and lively companions (62). Charlotte's achievements also made their impression; in summarising his initial attraction Eyre commented: 'Charlotte and I were very well-suited in education and interest. Besides, she was a very attractive and accomplished young lady! I loved her 
dearly'). He wrote of their 'shared love of words' and his admiration for her writing ability (65).

The couple's engagement was formally announced on May 251867 as Evans entered into her daily book of prayers the words 'engaged to Eyre'. A later entry then followed: 'Eyre and Charlotte's wedding day' (ATL MS-Papers-5135). Their marriage was officiated at by the Rev. Algeron Gifford and took place at Teaneraki in April 1868. The official wedding notice noted the couple respectively as 'the youngest daughter of James Lees Esq Teaneraki' and the 'eldest son of Captain George Evans and grandson of the late Eyre Evans, Esq of Ash Hill Towers County Limerick’ (ATL MS-Papers-5135). There had also been the recent arrival to New Zealand of Charlotte's new in-laws; Major George Evans and his wife Louisa, Eyre's sister Nina and younger brother George. It became a reunion to mark what Eyre later recorded as a 'special occasion', binding together the Evans, Lees and Moore families with 'even stronger ties' (Skillbeck 66). Following their marriage the couple went to live at Friston homestead where they were given the management of 'Friston Estate', consisting of a homestead and piece of land already belonging to the Lees' family property (69). The farm which came to dominate their lives for another ten years was 'somewhat drier' than other sections of the Estate (69). As a new son-in-law of the Lees Eyre was 'keen to emulate the effort and share the knowledge of those who had already a year or two more experience' (69). Charlotte, too, 'well knew the demands on a farmer's wife', having 'helped on the farm at Teaneraki ever since she arrived there in July 1864' (76).

Despite the isolated nature of rural settler existence these early years of Charlotte's and Eyre's married life exhibited close familial ties. Evans was surrounded by siblings and relatives; a pattern also constant in the plots of her novels (ATL MS-Papers-5135-06; 5135-09). Eyre and Charlotte viewed Friston as an ideal place in which to raise a family 
(Skillbeck 69). The birth of their first child was recorded, evidently to Eyre's delight, in the Oamaru Times on 22 September 1871 (76). Evans had twelve children, not all of whom were to survive (88). Three among the twelve siblings, Alice, George and Robert, were to die young (Alice at a few months, George in 1877 and Robert in 1879 at less than two months) (88)). The family's names were recorded at Lukes Anglican Church, Oamaru as: Ethel born 31 Dec 1868; Kathleen born 11 Jan 1870; Percy born 16 Sep 1871; Alice born 13 Sep 1872; Eyre born 14 Jun 1874; Lloyd born 28 Sep 1875; George born 15 Dec 1876; Savage ('Toss') born 05 Jan 1878; Robert born 23 Feb 1879; Eva born 10 May 1880; James born 08 Aug 1881 and Eric born 16 July 1882 (Oamaru Courthouse Records - see Works Cited).

\section{Domestic life}

In her role as wife and mother at Friston Evans herself remains a rather less visible figure. More than certainly (and as confirmed in her husband Eyre's diary) the demands of domesticity spoke for a great deal of her time being ostensibly similar to the lives of families mentioned in her novels (i.e. the Somersets in Over the Hills and Far Away and the Cunninghams of A Strange Friendship). Evidence of Charlotte's domestic life is found, once again, in Eyre's recollections where she is said to have been 'much occupied' with caring for children and domestic matters (Skillbeck 77). Eyre's memoirs occasionally recount rare insights into their everyday experiences. A conscientious man he tried his 'very best to learn and manage the estate' while his 'beloved Charlotte ran as comfortable and well-ordered a household as could be in our circumstances' (76). Earlier times in the couple's marriage had been prosperous enough to have allowed 'some help around the house' - a dispensation making them 'among the more fortunate' of local settlers (76). The shared life of the settler families, set amidst the primitivism of the frontier landscape and early township of Oamaru involved social evenings. These occasions as recalled by Eyre were enhanced by a mutual 'appreciation of the arts and a 
lively sense of humour' (77). On visits to Oamaru (and at Friston) Evans would likely have spent time among her wider circle of relations, perhaps enjoying informal entertainments in the Victorian manner, with Gifford Moore and Eyre each taking turns at singing and recitations (77). It was in the quiet evenings at Friston however, following a day's domestic activity, that much of her creative written work was achieved. Eyre states that Evans 'continued to write ... not only because it was something she loved to do, but also in the hope of earning some extra pennies to supplement our meagre income' (78). In a portrait of the pioneer novelist at work he saw his wife with her 'head bent over the paper on which she was writing', while 'the glow of the candle would light her page' (78). During these evening hours Evans also sketched her short stories, in addition to the novels later published in 1874 , with the more serious intent of eventual publication in mind.

The deaths of three of their children, though mourned deeply, were apparently met with a certain stoicism as the imperatives of pioneer existence again ruled Eyre's feelings ('death in infancy was such an occurrence then, but we, like others, tucked the personal heartache into our memories and got on with life') (81)). The couple's private grief is evident in Eyre's diary that reads: 'On 28 January 1873 our little Alice left us before we had time to know her. I purchased a plot in the general cemetery for two guineas' (81). Alice's name appears on the dedication page for A Strange Friendship. In another happier domestic anecdote Evans is remembered writing to her daughters (then staying in Oamaru) to inform them of Percy's pet sparrows (76).

Evans was also religiously minded. Of the two, wrote Eyre: 'Charlotte in particular seemed to draw great strength from her Christian faith', expressing 'the sincerity of her feelings in her poems and hymns' (75). The same sense of religious piety was again reflected in her religious poems or 'Sacred Verse'. Charlotte and Eyre contributed 
enthusiastically to local spiritual fellowship. 'Faith and Christian company' was seen as an indispensable element in the lives of the early colonists (75), as church news and reports of meetings supported feelings of solidarity with an accompanying sense of 'do unto others' as well as a spontaneity (75). The properties of Teaneraki Estate were situated some miles out of Oamaru so that Sunday meetings took the form of services read 'at the farm' at which the men gave sermons and when Evans could also give occasional readings. The overall effect was individual and to some extent 'evangelical'. At 'Cloon Eavin' the family built a wooden chapel named 'Bethel'. It was there that Eyre's sister Nina married Frank Ogilvie-Grant on November $24^{\text {th }}, 1874$ (76).

\section{The Farm at Friston}

Looking back with hindsight over the intervening years, I still see our time at Friston as one of my most treasured memories, despite our struggles - Eyre (76).

Life at the Friston homestead which lay adjacent to her in-law's at 'Cloon Eavin' symbolised probably the happiest years in Evans' marriage. The close proximity was by all accounts a desired and practical necessity, enabling the Evans contingent to 'farm together and support each other particularly at busy times' (70). Another property 'Big Hill' was purchased bringing the entire value of the Evans property interests to a total of 5,896.00 (70). Eyre's brother Trevor Corry and his youngest brother George ran 'Big Hill' conjointly with Eyre's father Major George Evans.

While the family all helped each other at these times, the reality of the return for our efforts did not often meet our expectations, let alone our hopes - Eyre (70).

Eyre's memoirs also relate that frontier life, even for colonists such as the Lees and Evans, was not without its many challenges and difficulties. Though the new landscape may have had similarities to English scenes so familiar, the New Zealand climate and 
conditions still held their own sway. Farming incidents outlined by Eyre in his memoirs may too have impressed Evans the novelist, who wrote of storms and flooding in both Over the Hills and A Strange Friendship. Eyre's diaries record a range of sporadic incidents happening at Friston with 'stacks' being on fire and, even more dramatically, 'enormous floods on the Waiareka Creek' and 'houses washed away with their occupants inside' (72). Occasional extremes of weather could cause creeks bordering property to rise 'ten feet above the normal level' (72). As Eyre recalled, 'winter rains would be late, while drought would be the word on everybody's mind' (72). Of especial mention in the family records of that period was a person described by Eyre as ' $\mathrm{Mr}$ Common', a grocer who 'kindly extended credit to us on many occasions till we had the wherewithal to pay our bill' (70). Eyre's first views of the new landscape resemble those often found belonging to the romanticism of New Zealand's early pioneer period. He wrote of nature's own stunning visual palette, offering the firm declaration that 'no artist could produce anything like an adequate representation of the beauty of colour and panorama that surrounded us' - of hills that 'stretched away to the north, while to the west an impressive range of mountains rose in grand peaks to the sky' (58).

\section{Men and Women of the Colony}

As a family with significant land holdings, in the Waiareka Valley and around Oamaru, we all felt we shared a moral and civic responsibility to contribute to the development of the district - Eyre (74).

In their observations of life and social preoccupations as settlers the Lees and Evans' households incorporated into their immediate outlook a middle-class Victorian conventionalism and sense of 'English genteelness' (Robinson and Wattie 168). As evidenced in Evans' fictional writing their correspondence expressed an in-built awareness of privilege that anticipated the future with forebearance and a degree of 
optimism. Over time, the colonists became proud of being 'colonial'. In the naming of their homesteads the families reflected a settler tendency to emulate a form of 'landed gentry' after the English social pattern (Arnold 159). Accordingly as men of property and education, the Lees and Evans' blended a certain romantic idealism with their role as energetically inspired 'Empire' colonists. In the immediate locality of Teaneraki District and in Oamaru they cultivated an outlook toward egalitarianism, carrying a belief in shared workload that would, they hoped, ultimately improve conditions 'for us all' (Skillbeck 74). For a new colony lacking in transportation the Lees' contributions to the surrounding community were to prove in many respects invaluable. Eyre and his father served on local Roads Boards, sometimes railing against the more vexacious aspects of early provincialism. As landowners they took a circumspect view of a taxation system in which 'landowners were taxed and their money 'matched pound for pound by the Otago General Roads Board' (73). They continued to provide local assistance nonetheless by being well represented on local Boards throughout the late 1860's and 1870's. The Lees also donated land to the district (81). According to Eyre, Charlotte's family was 'actively involved in setting up a school in the Upper Waiareka' (81), while the husband of Evans' sister Sophia, Charles Gifford-Moore, initiated Oamaru's first railway transportation system (74).

"I have been making the parlour carpet all day and I am tired" - Alice at Waihaorunga (ATL MS-Papers-5135-09).

The homestead and farm of Friston occurs later in the letters of Evans' sister-in-law, Alice Lees, to her sister Kitty in England in which she is referred to as 'Carlo'. Writing from 'Alverton' the letters of Alice Lees generated their own insight into a life similar to that of Evans, living nearby at Friston (ATL-MS-Papers-5135-09). For the few years of her time in New Zealand between 1872-1877 Alice provided a regular correspondence, with her non-fictional accounts of home and farm establishment at 
Teaneraki containing an urgency of the civilising of the frontier that in certain aspects echoed Evans' fictionalised versions of femininity and masculinity. Alice wrote, like Dolly Somerset in A Strange Friendship, of 'getting fresh flowers for the chimney piece' and making 'lovely bouquets of leaves and grasses'. Like the men in Evans' novels her husband was sometimes absent from home, travelling around the Canterbury region, in particular to Dunedin (ATL-MS-Papers-5135-09). On first arrival at Oamaru, Alice and James had been greeted with 'joie de vivre' by relations then resident in New Zealand, at Oamaru beach. As with Evans' fictional colonists, Alice's correspondence frequently emphasised a dependence upon passenger ship mail commonly referred to as the 'English Mail' (Skillbeck 79).

"First of all I wish you were here. We should have such fun and I have such lots of things to do that I think Kitty would like to do with me as she used to do at home" - Alice (ATL-MSPapers-5135-09).

Similar to Evans' novels Alice's reports of the colonial domestic confronted the constraints of frontier existence and a 'gentility' wherein a greater share in domestic work could be needed than otherwise expected at 'home'. A similar sentiment is expressed in Evans' character Dolly Somerset's comment: 'Happy, in spite of hard work, to which we were all utterly unaccustomed' (ASF 20). Alice related in prosaic detail the births of children and progress in home alterations. With little mention of social entertaining her words were tinged with hope, or a feeling of 'good prospects'. The women of her class habitually brought out domestic help then hired more servants once established in the colony (Skillbeck 80). Hence domestic incidents such as that involving Bella Stewart, a nurse also employed in Evans' household, were frequently reported, along with news of 'Mother's Meetings' and reading groups being held in the locality of Teaneraki district to which young women came for supervised lessons in French. Alice's letters do not recall Evans participating in those occasions, however 
passing announcements were made of births and new arrivals at Friston (ATL-MSPapers-5135-09). The more survivalist aspects of frontier life again earn mention in Alice's consternation over neighbours ('a wife beater within stone's throw') and occasional frustration over estate matters. Already she perceived a bias in attitude by those at 'home' toward life in the colony, exclaiming: 'Really people at home are stupid. One part of New Zealand seems all the same as another to them' (ATL-MS-Papers5135-09).

\begin{abstract}
"What romance there has been in colonial life, has departed with the growth of the country and I suppose there can be nothing much more prosaic and matter of fact than the lives of young settlers out here" - Alice (ATL-MSPapers-5135-09).
\end{abstract}

By 1873 Alice was conveying nostalgia for a fading sense of 'romance' in the early colony that mirrored Evans' own thoughts in her 'Preface' to Over the Hills in which she reflects on the 'continually altering' nature of the local and peopled landscape' (OHFA 'Preface'). As a correspondent Alice's optimistic expressions and sentiments formed a parallel with a style of middle-class settler writing similarly characteristic to that of her contemporary Lady Mary Anne Barker, author of Station Life in New Zealand. From 'Waihoranga', in 1876, she wrote the following:

"Things have materially changed since you and James rode over here 3 years ago, or anyhow since the land fever set in - it is still raining. It is a glorious country. I do like these tussocky hills. I think I am getting very fond of New Zealand" - Alice (ATL-MSPapers-5135-09)

\title{
The Writing Years
}

Throughout the Friston years writing became for Evans not only a source of private enjoyment but also an increasingly professional activity. The correspondence with her 
publisher, Sampson Low, and the reviews that followed, created their own excitement among those at Teaneraki. From 1874 Evans might have written with even greater purpose, yet it appears that much of her work was by then completed. Upon publication Evans was pleased 'that her stories set largely in the New Zealand landscape had 'appealed to her fellow colonial readers as well as those in England' (Skillbeck 79). Reaction to her writing successes within the Lees circle was in general unanimously supportive. The publication of Over the Hills and Far Away in hardback by Sampson Low and its arrival at Friston, bearing the inscription 'to my husband', had been a pleasant surprise for Eyre (78). Shortly after Sampson Low's commissioning another story Alice Lees wrote home to England that 'Carolo was bringing out a story in one of the English magazines', urging them to 'please buy the book A Strange Friendship: A Story of New Zealand Life (ATL-MS-Papers-5135-09). Evans' relatives at Teaneraki noted a further review appearing in the Otago Guardian on [26 October]:1874:

We have read A Strange Friendship thrice, and
it seems to acquire fresh beauty on each
perusal. We congratulate Mrs Evans on her
work and hope to hear of her again, and we
congratulate New Zealand on the possession of
an author capable of writing with such
sweetness, power and pathos - Review Otago
Guardian (ATL-MS-Papers-5135-09).

A family local 'legend' and ancestral connection with a title known as the 'Seafield Inheritance', or 'Earldom of Seafield', constituted yet another point of reference for Evans the 'romance novelist' (Skillbeck 93). 'The Seafield Inheritance' was unique to its New Zealand context, providing a link between Britain and colony that surpassed Evans' lifetime, yet, in the breadth of its saga, continued its grip on family mythology. Frank Ogilvie-Grant's accession to the title 'Viscount Reidhaven' whilst still resident in Oamaru was not fully realised until 1884, two years after Evans' death in 1882 (93). At the same time Evans' novelistic imagination of Empire romance absorbed the ancestral heritage of her in-laws, Major George Evans and Louisa Corry, who by then were living 
at 'Cloon Eavin' (69). Her husband Eyre looked also toward 'Ash Hill Towers' - the place where he had been born and where his father George had grown up - in addition to 'Narrow Water Castle' in Newry, County Down, the ancestral seat of the Halls (9). Working from her colonial sitting room at Friston Evans may have found something of her own escapist fulfilment in writing these same themes - of ancestral ties always somehow beyond reach - into her storylines (such as that of Alan Ainsleigh's inheriting of 'Curtis Knowle Estate' in A Strange Friendship). The other side of Evans' inner life dwelt also on the prospects of human relationship. At the borders of her imagining during the years at Friston was the mutually interdependent nature of men and women in their social relationships in the colony. This meant for women a cultivated subservience to an economic order of frontier survivalism and inherited custom. Although, at least on the surface, those in her immediate circle possessed a compatible 'gentility', Evans engaged with more archetypal feelings. Heavily dependent herself upon her men for economic support and social identity she dreamed of their opposite.

\section{Last Years}

For a period of years the circle of kinship which characterised the Evans, Lees and Ogilvie-Grant families had been rurally based at Teaneraki. The year 1877 marked a turning point. In 1876 the Teaneraki Estate properties in the Waiareka Valley, excepting that at 'Big Hill', were sold and the Evans and Lees families moved to Oamaru (83). James and Alice Evans returned to England and the Frank Ogilvie-Grants (related by marriage to Eyre's sister Nina), having also farmed in the area, joined the Evans' in Oamaru township where Frank and Eyre worked at various jobs to maintain their growing families (93). The move into Oamaru meant a closer proximity to some of the social events and opportunities regularly advertised in the pages of the North Otago Times, more notably, the calendar of the Oamaru Athenaeum and Mechanics Institute (see Appendix 1). Evans' own activities continued however to focus around her children 
and immediate relations; in particular Charles Gifford-Moore (by then re-married) and the Ogilvie-Grants. As parents, she and Eyre were ambitious for their childrens' schooling to advance, but were feeling the effects of a more insecure period (87). Following the sale of Friston Eyre continued to find sporadic employment. At this time (according to Eyre's diary which provides no further detail, however, on the subject) Evans had the unexpected windfall of employment 'on the staff of a leading periodical' (87). More than likely existing contacts with overseas publishers such as Sampson Low and The Family Herald may have proved useful. For a time, with Evans enjoying an opportunity to engage her literary (possibly editorial) skills in a paid position, the domestic affairs of the household progressed 'smoothly and satisfactorily' (87).

Changes in her family circle continued to affect Evans' last years. There had been the deaths of three children and now the demands of her domestic life were, if anything, more pressing. She missed her sister Sophia who had died in the early '70s. In 1877 her friend and sister-in-law Alice Lees died, suddenly, on the return to England only a day before arriving at Liverpool (88). Evans' other sister-in-law Edith also died upon returning to England leaving her brother Joseph with a large family of 16. By the late 1870's Evans was relatively bereft of those with whom she had first emigrated to New Zealand back in 1864 . Her pregnancies continued with the birth of six more children: George in 1877; Savage ('Toss') in 1878; Robert in 1879; 'little' Eva in 1880; and James in 1881. On 22 July in the winter of 1882 soon after the birth of their last child, Eric, on 16 July, Evans died of 'childbirth' fever. This event left Eyre with a family of nine to support aged between 6 days and 13 years (87). A brief notice marking Evans' death was recorded shortly after in the North Otago Times on 24 July 1882 . At that time the family were situated at Eden Street. She was buried close by her other relatives in Oamaru Cemetery. No obituary was published. She was recorded as 'Charlotte, the beloved wife of Eyre Evans, aged 40 years' (ATL-MS-Papers-5135-09). Although he 
was to marry again, having another son Thomas Charles in 1890 with his second wife Mary, Eyre's remembrance of Evans as companion wife, helpmate and writer/novelist maintained its hold (99). More urgently it was his sister, 'Aunt Nina' Ogilvie-Grant, who came to his assistance as governess and helper in the months following. To 'try to make the best of things' Eyre moved the family into a smaller residence in Eden Street (Skillbeck 93).

\section{The Family Herald}

Eyre's later years were characterised by a period of travel and more active journalism. A committed Christian socialist, Eyre was a keen contributor to the North Otago Times (246). Over the years he had kept a series of notebooks entitled 'Stray Thoughts', in addition to a number of scrapbooks filled with newspaper cuttings and articles published over the years on 'Temperance' (61). As the colonial newspapers, including the North Otago Times, led public discussion on the all-important topic of the social problems of unemployment and drinking, Eyre joined in with those speaking out on the subject (246). On visits back to England in the 1900s he attended lectures and wrote articles for British newspapers, among which was The West End Press [ATL-MSXPapers-3945]. The name 'Charlotte' continued to be mentioned from time to time, more particularly in connection with The Family Herald (JOG 197). In a scenario suggestive even of Evans' sensation novel, the story concerning posthumous publication of her short stories began with a letter; one published by Eyre in a London paper. The letter in turn led him to a relative living in Richmond (197) where he was enlightened to Evans' stories being about to be re-printed in The Family Herald (her former publisher). Among them he recognised one that looked remarkably similar to another he had helped his wife revise some time earlier entitled 'Our Nearest Neighbour' (197). A protracted correspondence followed with the editor of The Family Herald; the first letter dated $15^{\text {th }}$ July 1903 launching an inquiry over copyright that took some months and considerable 
'chance' to negotiate satisfactorily (198). Evans had formerly received a five pound payment for each of the stories: Only a Woman's Hair, A Narrow Escape and Our Nearest Neighbour. After repeatedly requesting that all three be accounted for, Eyre managed to locate Our Nearest Neighbour as No. 121 on the list of a series produced by The Family Herald called 'Happy Hour'. In a recapitulation of the mysterious 'clue' familiar to Evans' novels The Family Herald agreed to a full settlement (200) as Eyre received a final letter from the 'Herald' disclosing that the stories had, in fact, previously appeared in a 'Magazine of Fiction' series (which was 'unlikely to be republished' (200).

\section{Epilogue}

After 1882 Eyre wrote that he hoped to one day publish Charlotte's poems. This aim was to be affected by the Great War of 1914-1918 in which their sons, like others in the district, inevitably became involved (245). Four of the children, including 'Tom' from Eyre's second marriage, served in the Gallipoli and Boer campaigns while Percy and Eric remained stationed in New Zealand. Tragically another son James was killed in action while serving in France in September 1916 (244). Having found solace in Evans' words during these war years, Eyre brought out finally a local edition of her selected poems under the title Poetic Gems of Sacred Thought that was printed and published by J.H. Cunningham and Son of Wear Street, Oamaru (245). Those of Charlotte's children to marry included Ethel, who in 1890 married Robert Milligan, a businessman and later Oamaru Mayor (99). Eldest son Percy was at one time on the staff of the North Otago Times, while Eric, practising in the pastoral ministry, followed his parents' Christian beliefs and served during the war years as an army chaplain (245). Kathleen ('Kitty'), however, died young at 22 years while living in England (100). On the 22 August, 1919 Eyre died aged 77 years. An obituary was given in the Oamaru Mail the following day on 23 August (248). Of all Charlotte and Eyre's seven surviving children only Thomas 
Charles, the son of his second marriage was to continue the Evans' name in Oamaru into the $20^{\text {th }}$ century. The saga of the three closely interlinked colonist families dispersed somewhat over the next hundred years with descendants of Eyre and Charlotte's marriage becoming situated mainly between England and Australia (ATL-MS-Papers13-19-1). In this way the family name carried on the theme of diaspora between nations and continents, Europe and the antipodes, synonymous with Evans' 'Early Pioneer Period' writing.

\section{Part II}

\section{Evans' Social Milieu}

Dunedin was a straggling town, lying on the side of a hill extending down to the water, with three or four wooden jetties running out into the bay (Skillbeck 77).

As a colonial author, Evans reflected her locale by imparting a sense of the 'ad hoc' and the nature of survival in her work; combining elements of custom in dress, manners and interior furnishings with the need to accept, as Dolly in A Strange Friendship says: 'hard work to which we were all utterly unaccustomed' (20). Though Evans' characters were comfortably middle-class, they were reminiscent of the embryonic culture Evans herself inhabited. The characters presented in the novels Over the Hills and A Strange Friendship were thus men with some capital to invest in land and the building of 'homesteads', or a working class people of domestic servants and farm labourers. Accompanying them was also a 'rogue' element of footloose, educated young men and 'suspicious' women - even the occasional disinherited aristocrat. Such characters appeared in most main towns or growing cities of the colony having arrived off passenger ships, and, like the entertainment troupes, been travelling en route from 
Sydney or Melbourne (the latter of which features in A Strange Friendship as does New Zealand's provincial city of Auckland) (North Otago Times 1874). During the years 1864-1882 of Evans' residence in Oamaru, the township was a major port for the Otago region, with Port Chalmers as the main disembarkation point for emigrants. The busy port docks of the region, with their passing to and fro of ships and supplies for maintaining essential survival needs for local inhabitants, reflected the progress of a colony regularly advertised in the newspapers. Featuring in the North Otago Times of 1874, the year in which Evans' novels were published, a wide spectrum of public notices was in evidence for goods and services, along with regular opinion columns and news items. By 1874 the small town with a population of approximately 2,000 , boasted dining rooms, boarding houses, hotels (including the now historic Empire Hotel) retail businesses and civic entities such as a Magistrates Court (North Otago Times 1874).

The colonists of Evans' early social milieu sought to recreate forms of social life they had left behind. As early as the 1860's organised public and local entertainment was beginning to develop; an example of which occurs in Over the Hills' Chapter XIV entitled 'The End of the Concert' (OHFA 146). According to Eyre Evans diary 'concerts and fundraising entertainments were regularly advertised in the newspapers' (77). The 'playbill' on those occasions included pianoforte solos ('Fantasia from Faust') and vocal recitals of a sentimental flavour (North Otago Times [November 3]:1868.). Songs at 'soirees' captured an Empire spirit which, though in many respects relatively forward looking, also liked to feel its sentimental ties in song titles such as 'My Heart is Over the Sea' and 'O Erin, my Country' (North Otago Times [October 10]: 1869). In Over the Hills, Evans inserted a similar scene where Clinton Meredith's 'last solo' is followed by - 'a glee' and 'God Save the Queen' (OHFA 146). 


\section{The North Otago Times}

Oamaru lifts up her voice against Dunedin just as loudly and on almost identically similar grounds as Timaru does against Christchurch (North Otago Times [April]:1867)

The reading milieu into which Evans' publication of two early pioneer novels made their debut in 1874 was dominated by a relatively vigorous print culture belonging to the period of transtasman publishing called 'Maoriland' (Stafford and Williams 11). This phenomenon of newspaper journalism in turn provided the background for Evans' novel themes of criminality and what she often looked to as 'colonial'. In the making of the new colony, a quite speedy development of print culture coincided with an emergent society to which Evans herself related, that viewed itself as a function and reflection of wider Empire and therefore a social and cultural extension of Britain - the "mother country'. What was then considered 'local', 'national' and 'international' comprised a significant portion of the newspaper's feature columns; topics of which included the problems of colonial provincial administration and central government. The vigour of local discussion was also symbolic of the young surviving colony, embodied by Evans and her circle of kin, and faced with the reality of geographic distance from their cultural homeland of Britain. The platform of newspaper debate to which Evans' husband Eyre contributed often centred around themes of 'colonialism', 'provincialism' and the 'pioneer'. Among reports of political tension between urban and rural interests in the Canterbury region was the article 'Provincial Abuses and It's Remedy', a title suggestive of concerns similar to those felt by the Lees in Oamaru (North Otago Times [April]:1867 - see Link). The topics of colonialism and being colonial also popped up at end-of-term school addresses; an example being Judge Richmond on the same use of the term by people of 'education and refinement at home' (North Otago Times [January 31]: 1871) - see Link). 


\section{Local Journalism}

Examples of amateur writing and fiction began to be offered in the North Otago Times from around 1865. Evans was among the earliest women contributors to the paper, having had her first novel, Guy Eversley, serialised in 1865-1866. Fiction also appeared, with short stories occurring less regularly than poetry. The poetry columns: 'Poet's Corner', 'Original Poetry' and 'Select Poetry', created an outlet for sentiment that was introspective and reminiscent of internal states of mind not necessarily tied to locality or the experience of being colonial. Poems were in general imitative of the traditional, rhyming forms and voices of popular sentiment recently left behind in the British Isles. In their reference to geographical distance between 'home' and 'colony', many of the poems may have sought to alleviate feelings experienced by the colonists. The implied prospect of no return brought a degree of pathos to simple and often clichéd verses - as in the following (North Otago Times [October 21] :1869):

Oh! For a poetic lay,

To tell in noblest strain

The love I feel for one, perchance,

I ne'er may see again.

Literary reviews were published in the North Otago Times from as early as 1867 (including those for Evans' in 1874). One written by a William Hay on the early pioneer period novel entitled Grif: A Story of Colonial Life by Benjamin Farjeon cited the work as 'excellent', though yet 'unequal', to its predecessor Shadows on the Snow (North Otago Times [October 15]:1874). Unlike Evans' romance stories of New Zealand and their themes of social class and gentility, Farjeon's 'Grif' character was seen by Hay as signifiying a code of morality 'rather of the loose kind'. In his argument 
that Farjeon's 'Grif' was 'detached' with no real plot, Hay's review highlighted the formative nature of early pioneer period writing (North Otago Times [January 11]:1967). The sensation style of novel to which Evans subscribed also raised a degree of speculation in the local press. An article in the North Otago Times of 1874 in particular queried the suitability of a recent novel trend whose essentially 'false' tone might foil a reading public of 'weak and pernicious readers' (North Otago Times [October 15]: 1874).

\section{The Oamaru ‘Athenaeum' and Mechanics Institute}

By 1874 at least a portion of the local population of Oamaru were sufficiently literate and receptive to support a newspaper industry. A public lending library was however yet to become established (Grenfell 1). The 'Athenaeum' - to which novelist Janet Frame as winner of a school prize much later received subscription (Frame 71) - was then instrumental in laying the foundations for a potential readership for Evans' works of popular romance which were included in an 'Institute' catalogue (see Appendix I). Funding initiatives, sometimes in the form of amateur concerts, were at that time mostly supported by a small yet educated middle-class. Correspondence in the North Otago Times demonstrated a degree of support existing also among the wider populace (North Otago Times [25 July]:1877). The Institute's reading room conveyed a primitivism, of isolated gentility, similar to that found in Evans' portrayals of frontier sensibility; in the cultivated, yet strangely 'uninhabited' interiors in the Ainsleigh and Cunningham station homes from Over the Hills and A Strange Friendship. The building which later became the 'North Otago Museum' was opened in 1882, in expansive Victorian style, by the Hon. Mr Rolleston, Minister of Lands, Immigration and Education. Rolleston's speech paid tribute to what was the latest architectural acquisition in a town 'already celebrated for the beauty of its situation and the excellence of its buildings' (Grenfell 5 ). 


\section{Publication History}

The story of Evans' writing was characterised by an overall creativity that was quietly celebrated, yet lacking a clear chronological pattern. This was in part due to a lack of evidence surrounding the first publication dates for Evans' stories. Family correspondence and diaries surrounding Evans' publications indicate that writing was seen as a means toward livelihood (Skillbeck 78). Except for a short period of time, when Evans reportedly worked on the staff of a 'leading periodical' in the late 1870's, there is little indication of her producing any significant pieces of writing after 1874 (87). Prior to 1874, the year of her novels being published, Evans had been associated with a London periodical named The Family Herald (78). Following publication of 'Guy Eversley' in the North Otago Times it appears Evans would have been mainly preoccuppied with The Family Herald - cited as a 'domestic magazine of useful information and amusement' (78). The short stories: Only a Woman's Hair, A Narrow Escape and Our Nearest Neighbour were located sometime later in the 'Herald's 'Happy Hour'; a series that was published between 1866-1874 (either 'as short stories or in serialised form') (78). Evans' novels had a preliminary association too with The Family Herald, since Over the Hills had first been submitted as a draft for a short story prior to it's being discovered by Sampson Low. The firm wrote to Evans with the suggestion that the story be re-worked as a novel, offering her an advance of twelve pounds (78). The news of this success brought forth an enthusiastic response from Alice Lees, while Evans wrote as follows:

"You will be glad to hear that the money for my story has come last mail - at least a letter came from the Editor saying he had accepted the story and would send me a cheque immediately. But it is not as much as we hoped it would be - it is only twelve pounds ..... so I cannot send you any money to spend for me in town at present but perhaps I shall get some more for another story some day" - Carlo (ATL-MS-Papers-5135-09). 
Shortly after, Evans received another letter from Sampson Low requesting a second novel (78). The next book, entitled A Strange Friendship, for which she received the same payment of twelve pounds, came out later in 1874 jointly published by a New Zealand firm Reith Wilkie of Dunedin (78). Reviews soon followed in the North Otago Times and Otago Guardian. During this period Evans was more than usually preoccupied with providing the additional chapters for Over the Hills and writing her second novel. The publication of Over the Hills and Far Away and A Strange Friendship secured her local reputation as a colonial novelist. The posthumous phase in Evans' writing career didn't occur until after Eyre had obtained rights to re-publication of the short stories, in 1903, under the title Only a Woman's Hair. Two of the stories in the collection of three novellas i.e. A Narrow Escape and Our Nearest Neighbour had already come out in The Family Herald Press some years previously in 1900. These later events were at least to serve in restoring copyright ownership again under Evans' name. In 1917 a selection of Evans' poetry, representing a more directly personal aspect of her writing, was finally published by the New Zealand firm J.H. Cunningham and Son as Poetic Gems of Sacred Thought (245).

\section{Reviews}

Pictures of colonial life are given with great vividness and a minuteness of detail that is refreshing. - Review (ATL-MS-Papers-513509)

The reception to Evans' work in local newspaper reviews - such as those appearing in the North Otago Times and Otago Guardian - was in general favourable. Local papers expressed support also for the development of a 'colonial literary industry' of which Evans was viewed as representative (ATL-MS-Papers-5135-09). The critics, including J.G. Flatt, drew attention to the novels as products of popular romance and as 'stories of 
New Zealand' with a flavour of the colonial somewhat unusual to contemplate (ATLMS-Papers-5135-09). These reviews reflected the primarily Empire-driven period of 'Maoriland' fiction (1872-1914) with Evans' saccharine and picaresque narratives seen as 'pretty descriptive passages ... honed with the hand of an artist who evidently loves her task' (ATL-MS-Papers-5135-09)). While critics observed that in neither work did Evans' story 'hinge upon any peculiar phase of colonial life', her New Zealand-based characters earned attention nonetheless as the 'creatures of her fancy' who were made 'thorough colonists' (ATL-MS-Papers-5135-09). One of the reviews, dated as early as February 1874, arouses some speculation as to the actual order of publication for the novels (MS-Papers-5135-09: MSX-3976).

Of each of the novels Over the Hills received two critical reviews, both in 1874, by local newspaper critics; one singly and the other in conjunction with A Strange Friendship (ATL-MS-Papers-5135-09). The North Otago Times featured a lengthy review for $A$ Strange Friendship (see Appendix I). Another for A Strange Friendship appeared in the Otago Guardian on October 26th. Critics attended to plot and narrative style, considering Over the Hills to be 'well and gracefully told', while the plot of A Strange Friendship was thought by one (unnamed) reviewer as the more 'cleverly conceived'. Over the Hills, on the other hand, was seen as 'somewhat sketchy and without complication of by-plot' (North Otago Times [February]: 1874). Critics also noted Evans' skill in managing her storylines, with that of A Strange Friendship in particular being effectively 'maintained to the end'. A Strange Friendship also received praise for its swiftness of plot and economy of style, thereby eliminating the need for readers to skip 'tedious parts' in the story (ATL-MS-Papers-5135-09). Reviews responded to the 'improbable' as it related to both works. The circumstances surrounding the novel's arch villain Richard Carewe's introduction to the plot of A Strange Friendship was questioned and his dubious and criminal character cited as 'unfortunately real enough'. 
An insightful and descriptive review of A Strange Friendship appeared also in a more perusing look by a North Otago Times critic who offered the opinion that a certain local paper had been 'strongly condemning' of Evans' second novel. Overseas reviews, however, such as one cited in the London Times, had instead congratulated the ‘authoress on a genuine success' (North Otago Times 1874).

\section{Part III}

\section{Novelist of the 'Romantic Frontier'}

Evans was among the earliest of colonial authors to contribute a version of popular romance literature that was both situated in the exotic and set in New Zealand. The colonising world which Evans daily inhabited represented a changing social milieu that inevitably coloured her work. In the process of departing from what could be described as autobiographical, to venture into the realm of the improbable, or sensational, Evans incorporated features belonging to the contemporary sensation novel then popularised by Wilkie Collins (Jones 125). Her works were a version of the colonial novel based on settler culture which could also be termed a 'domestic hybrid of romance and realism' (Shires 61). Evans' work conformed, at least to some degree, to the Oxford History of New Zealand Literature in English's 'primary modes of the Pioneer novel' i.e. 'naïve realism', 'exploitive conventionalism' and 'didacticism' (122). In the first instance of 'naïve realism' (122), unlike those pioneer novels representing 'a fictional extension of the non-fictional 'literature of occupation' (122), Evans' work was focussed strongly within the conventions of popular romance narrative, while her characters were situated as colonists with assumed 'biases and values' (122). In terms of 'exploitive conventionalism' (122), Evans' melodramatic plots relying on conventional family patterns of a colonising society and set in New Zealand, reflect Jones' 'pioneer pattern of appropriation' involving New Zealand materials within an 'existing conventional 
formulae' (122); thirdly in terms of 'didacticism' (122), Evans' use of a 'moral message' as a narratorial device is also seen to parallel Jones' 'use of New Zealand materials' in fictions for which 'a moral, religious, or political message' is relevant (122). The sensation genre in which Evans wrote has been cited as controversial and at the centre of a debate which questioned the role of the popular novel in a 'rapidly changing society' (David 1). In the cause of a romance writing that incorporated elements of the gothic, Evans herself employed a Victorian 'domestic realism' or domestic style in the placing and description of her characters and colonial sitting rooms - for which 'chintz sofas' and 'paisley piano shawls' (David 2) combined with 'pianos, croquet and the drinking of claret' (Robinson 169) .

As works of the early pioneer period, Evans' novels and short stories related to the Maoriland era in transtasman publishing which marginalised or appropriated the 'indigenous' (Stafford and Williams). Evans' Empire style romance blended with a saccharine frontier landscape, which, in its undulating hill tussock and mountain scenery, might as her critics have suggested been in Britain if it weren't for the convenient mention of a Maori placename or native flora and fauna. Yet as viewed by contemporary critics, and seen in their own time period of 'Maoriland' writing, Evans' novels in particular appear to have met the needs of Empire readers and critics alike as forms of colonial literature (Stafford and Williams, Introduction: A Land Mild and Bold 1). Also serving the aims of escapism, Evans provided her own milieu of New Zealand as the convenient setting for her story plots; a place wherein the mainly 'respectable' dissident or disaffected character could resolve their past dilemmas and a place over which disenchanted heroes and whimsical heroines of leisure could deliberate with ennui and nostalgia. In her role as a romance novelist, Evans managed to infiltrate these scenes with aliveness, candour and flashes of mockery and irony. 


\section{Theme}

Seen as a reflection of the Victorian middle-class pattern (Pykett 1) Evans'own family circle at Teaneraki from which she took inspiration could also adapt to a form of 'sensation' writing which identified criminal or deviant behaviour within a veneer of social respectability. By 1874 this aspect of sensation writing had already aroused concern among local newspaper critics (North Otago Times [October 15] 1874). Peopled by a society of conventional tastes and social ambitions, Evans' works explored a world of manners surrounding the propertied classes, while at the same time they exploited the sentimental and melodramatic qualities of popular romance. This included the indispensable elements or rituals of marriage and courtship. Her characters were English colonists, arriving to settle in the Canterbury region of South Otago, in what might be termed a version of the English rural 'gentry' (Arnold 159). Central to the characters' thoughts was the task of establishing a new home in New Zealand that involved the setting up of a 'homestead' or station home (see Appendix I) - and even more significantly - of becoming suitably acquainted with neighbours. In Evans' fictional versions of colonial life, however, these perceivably laudable and realisable aims were soon to become subject to other or unexpected influences. Of paramount significance to the (mainly women) consumers of Evans' brand of Empire romance was thus the consequence, of a social and moral non-conformism, which could then be safely negotiated in a geographic location that was remote, yet enticingly similar.

\section{Characterisation}

The relative homogeneity of Evans' characters contrasted with the 'other' in 'stock' characters from early pioneer novels, such as Farjeon's working class 'Grif' (Jones 121). In contrast to 'Grif', who must seek his identity at the periphery of a landowning, or relatively affluent middle-class, Evans' characters become subversive by their own volition. Evans used the sensation elements of crime, mistaken identity and sexual 
misalliance to disrupt the conventional expectations of her colonists, and thus also reverse what would be considered normative in the 'functioning' Victorian family of the 'respectable classes' (David 97). Evans represented what was then normative in dress, custom and social decorum via masculine and feminine stereotypes, while also allowing for hints of patriarchal dominance to intrude among her family portraits; (as seen in the outbursts of temper by Lucy's father in Over the Hills (OHFA 95)). In Evans' novels men were dissolute and 'cavalier' or hardworking and resilient. Women, on the other hand, were staged as decorously aloof or 'plain' and virtuously homely. According to romance convention Evans' hero and heroines also underwent trial by ordeal and spiritual suffering before they could be satisfactorily united, either on earth, or in the case of Lucy and Dacre in Over the Hills, in a union of 'eternal' fidelity (Chapter 33). In addition, Evans' faith in the reformation of her characters' dispositions and fortunes formed a pattern of resolution that was recognisable elsewhere among the generality of her published and unpublished work.

\section{Literary Works}

\section{Guy Eversley}

(Published in serial form Oamaru Times [October 5]:1865 to [January 4]:1866, ATL MS)

Evans' earliest published work Guy Eversley was serialised in the North Otago Times in two-chapter instalments. The serialising of the novel in a newspaper reflected also the popular trend that 'Victorians' did not in general purchase their 'serious fiction' (Flint 20). The story first appeared in October 1865 and ran over several months until 18 January 1866. Guy Eversley was among the first such stories to be serialised in the 
Oamaru newspaper. In 'The Puritan Paradox' Guy Eversley is cited as 'unique' to the romantic genre of pre-1940 New Zealand fiction being written 'from the male perspective' (Moffatt 19). Although focusing on a male narrator Guy Eversley's storyline still reflects Evans' familiar plot characteristics of marriage, and Christian piety, set among the colonial temptations of vice and greed.

Like Evans' two novels Guy Eversley's plot concerns the themes of avarice and marriage, property and subterfuge, with the eventual choice of a marriage partner gained through trial and suffering. Guy Eversley's plot is, however, based mostly in England with only a short period of the main character's time being spent in New Zealand. As in A Strange Friendship, the story line in Guy Eversley concerns a tale of fraudulent behaviour over inheritance and financial matters. Guy has a friend named Elliot Hope, whom he aims to disinherit in the expectation of gaining wealth and position. Evans then foils Guy's plan by placing a strong and equally manipulative character in his path in the person of Cora Brandon with whom he becomes infatuated and falls in love. Cora, a 'cold, proud, self-confessed adventuress' (Moffatt 20) instead refuses to become his wife, which precipitates Guy's departure for New Zealand. Evans then uses New Zealand as the place for escapism, the scenario for the reformation of the hero's character, and the resolution of Guy Eversley's plot. Guy must spend a period of time in 'honest' toil in New Zealand before he can earn the right to inherit a fortune and return to England. Cora Brandon has, in the meantime, also undergone a form of selfpurification through the tragedy of an accident which has left her blind. In a reversal of the Jane Eyre plot, where the male hero Rochester undergoes physical disfigurement, Cora's disfigurement makes her a 'fit bride because she has learned humility and selflessness' (Moffatt 20). To instil her point further Evans writes: 'Let us ... thank god that the sufferings as well as the joys of our earthly sojourning are arranged for us by a 
wisdom which is divine' (24), thereby referring to similar sentiments found in her collection of poetry Poetic Gems of Sacred Thought .

Over the Hills and Far Away: A Story of New Zealand

(London: Sampson Low, Marston, Low \& Searle, 1874).

\begin{abstract}
We have so few books of this class that it still seems strange to read of things which we think nothing of when enacted around us daily, but which at once strike us as being peculiarly colonial when we meet them in the course of an interesting story - Review North Otago Times.
\end{abstract}

Evans' first novel was written in 33 chapters, with a short preface by the author and dedication page. Of Evans' two novels, Over the Hills can be seen as more directly akin to the author's own autobiography. In the emigration of Lucy Cunningham aboard the ship Flora McDonald which occupies the opening chapters, Evans is seen to explore her own journey to New Zealand aboard the Chile. This includes mention of the white cliffs of Sussex as the Flora McDonald's initial departure point for the colonies - a familiar landmark too for Evans. A brief survey of Over the Hills and Far Away sees Lucy's departure from England accompanied by her brother Louis aboard the Flora McDonald. Lucy's relates her ship journey in a diary during which several of the story's main characters are introduced, including the 'mysterious' Mrs Keith. Lucy's diary ends upon her arrival in the colony. The story now shifts to South Otago and Lucy's new acquaintance with the Lennoxes and Winstanleys who are neighbours of the Cunninghams. The appearance of the Winstanleys and Lucy's meetings with the Lennoxes at Deepdene then involve a working out of marriage plots concerning the Cunningham and Lennox families. The two 'outsiders' Rylston Dacre and Laura (also 'Mrs Keith') then serve however to complicate Lucy's feelings of attachment to her 
shipboard 'fiancée' Clinton Meredith and instigate a covert, but growing affection between Lucy and Dacre. The resulting love triangle then ends in the climactic resolution of the suspense sub-plot regarding Laura's identity and Dr Dacre's past, as the novel's resolution of the marriage plot concerning Lucy is finally effected in a Christian theme of redemption.

In Over the Hills and Far Away the influence of the sensation novel begins to be felt as early as Chapter 1, when after a protected life spent in the company of her aunts, Lucy's breaking of ties with England among a group of strangers appears to plunge her into an adult world of hidden intrigue and romantic possibility that fits the gothic stereotype, yet is alleviated by the 'lighter' tone of the sensation narrative. While Lucy is ostensibly meant to be under the male protection of her brother Louis she often, paradoxically, appears to risk flirtation with a range of other male characters. In many respects as the central character and narrative subject, Lucy represents both a conventional female stereotype and a symbol of encounter beyond normal social horizons. This is evidenced in Lucy's early flirtation with Clinton Meredith and anticipation of life in the colonies (Chapters 1-7). In the image of the colonies and the social cocoon of the ship itself, Evans manages to find scope for a delectating pas de deux of amorousness, flirtation and worldly intrigue whilst maintaining a semblance of Victorian moral respectability. The question might then be raised as to the future meaning of the colony for the characters: is it to be a distant locus of escapism, of the socially dissident and ‘unsanitary' - or the place of prosperity, fortune and marriage? 


\section{A Strange Friendship: A Story of New Zealand}

(London: Sampson Low, Marston, Low \& Searle, 1874. Dunedin: Reith \& Wilkie, 1874).

We have read A Strange Friendship thrice, and it seems to acquire fresh beauty on each persual. Evans is cited as writing with 'sweetness, power and pathos. - Review Otago Guardian

In her second novel of 26 chapters, Evans' storyline centres around two principal narrators: 'Dolly' (Dorothea Somerset) and 'Alan' ('Alan Ainsleigh' alias 'Alan Carewe'). The plot concerns the mutual progress of the Somerset and Ainsleigh families in New Zealand who are neighbours living in the same district. Unbeknown to the Somersets, the Ainsleighs (Alan and his sister Madelaine) exist in a state of subterfuge, adopting a mode of living in lesser surroundings due to the need for secrecy. In the novel's opening chapters the Somerset family, consisting of Dolly, her younger sister Violet and newly married brother Harry and his wife Kate, have emigrated to New Zealand in the hope of building a prosperous new existence. True to romantic form, the sisters have not begun life advantageously, having been orphaned ('we had only each other and Harry') at an early age (ASF 3). In chapter 1 the narrative voice is in the first person, where Dolly reflects upon events that occurred in England prior to the Somerset's departure for New Zealand. Dolly's tone of nostalgia draws heavily upon a period during which she and younger sister Violet were close and as yet unaffected by the unsettling misfortune of their first years in the colony. At this time the two sisters had been living in a grange in Sussex and were bridesmaids at their brother's wedding. Violet's portrait is drawn in 'retrospect' as Dolly recalls her 'bewildering vision of beauty, with forget-me-nots in her hair the colour of her eyes' (3). However, during the journey out to New Zealand, signs are already beginning to show that Violet's lively temperament could persuade her into precipitous liaisons; the first being a 'young fellow-passenger' dying of consumption. Very little is mentioned of the voyage out to 
the colonies, described by Dolly in carefree, pleasant terms, before the young family commences the task of settling into the new homestead.

As the other of Evans' two sensation novels, A Strange Friendship appears primarily concerned with the interiority of the characters in relation to the sequence of events, with less emphasis on the pictorial qualities evident in Over the Hills. What arouses the reader's attention is the predicament of Violet and the 'strange' or unusual nature of her relationship with Madelaine, who unlike Laura in Over the Hills embodies not just name impersonation, but a complete sexual disguise. In her contrasting of Violet's physicality and lively impetuosity against Dolly’s plain 'little quakeress' (57), Evans also highlights two gender stereotypes, wherein the prettier woman is more likely to be seen as dissolute or fickle in nature, thereby ringing up the villain. Even the harsher realities of colonial living are contained within a saccharine coating of euphemistic descriptiveness. Thus A Strange Friendship fulfils the purpose of light sentimental fiction by presenting romance and human feelings more as a stylisation of actual life spiced with realism. Through the use of 'first person' and the alternating narrative voices of Dolly and Alan, Evans appears to stand back momentarily and allow her readers into a more direct

personal experience. In that sense there is a certain equality in Dolly's demure yet independent reactions. Within the pages of this ephemeral light popular novel, life and experience assume a vacariousness which, unlike Dickens, presents human character and life in the colony more as a pastiche of itself than society's realistic portrait.

\section{Three Short Novellas}

Evans' three novellas, all published under the single title Only a Woman's Hair are, like her two novels, each set in New Zealand and both emphasise Evans' tendency to promote a 'marriage-orientated outlook and Christian morality' (Moffatt 19). The three short posthumously published stories: Only a Woman's Hair; A Narrow Escape; and 
Our Nearest Neighbour, while written in the familiar style of saccharine style romance, nonetheless make their 'shocking' impact through Evans' melodramatic themes of murder and love entanglement. The Novellas were written prior to Evans' novels and in so doing offered a preparatory glimpse into her later development of the longer length, yet similarly themed, sensation novel.

Only a Woman's Hair - Three Short Novellas

(London: Family Herald Press, 1903).

The story's title refers to the kind of clue also akin to the sensation plot, being a lock of hair, the discovery of which arouses the heroine Cathie Pelham to the fact of her sister Rose's murder. Like Violet Somerset of A Strange Friendship Cathie flees the disastrous marriage she has recently made to Cyril Vane, only to fall precipitously into another romantic affair with a 'distant' suitor Noel Beresford. As in the romance of Lucy Cunningham and Rylston Dacre in Over the Hills and Far Away any temptation toward adultery must be 'sternly' resisted until the plot conveniently allows the pair to marry. This occurs when Cyril is shot dead and not, as it would happily turn out, by the heroine's preferred marriage partner Noel.

\section{A Narrow Escape}

In A Narrow Escape Evans reverses the marriage plot of Only a Woman's Hair by enabling the heroine, Estelle Raleigh, to be saved from marrying a murderer through the intervention of the 'hero' character of Hugo Northcote. The hero's actions are rewarded, in his marriage to Estelle, while the former threat to her happiness, Wilfrid, is removed through his suicide by drowning. It is further significant that in his role as villain Wilfrid should drown himself out of remorse - as Evans again 'teaches' that wrongdoing will not be rewarded. 


\section{Our Nearest Neighbour}

The recurring romance theme of romantic satisfaction through cultivation of virtue arises once again in the story of Mary Arnold and Eric Home in Our Nearest Neighbour. Here the hero and heroine must resist their attraction due to Eric already being married. This potentially adulterous or even bigamous plot situation also echoes a similar theme in Jane Eyre, since in Eric's unhappy marriage his wife Maud has a gambling habit. When Maud dies, Eric and Mary are then free to marry. In a romantic flourish Evans confers one of her own plot trademarks; that of Eric's inheriting both wealth and title, thus conferring a final touch upon the couple's wedded happiness on their return to England.

\section{Poetry and Miscellaneous Writings}

\section{Poetic Gems of Sacred Thought}

Published by J.H. Cunningham \& Son, Dunedin, 1917.

\section{Contents:}

'A Little While'

'Shadows - New Year's Day'

'A Crown of Glory that Fadeth Not Away'

'In the Cave of Abdullam'

'All that Glitters is not Gold'

'Until the Day Dawn'

'This Life of Ours'

'Outside the Bay'

'No Condemnation'

Evans' collection of poetry consisting of 'Poetic Gems of Sacred Thought' and 'Fragments of Poetry and Prose' often reflect Evans' own life experiences and religious beliefs. The poems total 10 in number. In general the poems are presented in 3-7 stanzaic, rhyming, verse couplets. Three of the poems: 'Too Late', 'All that Glitters is not Gold' and 'There's a Woman at the Bottom of It' were not however included in the 
published selection. Many of the poems discuss biblical themes of faith and redemption and a belief in inner divinity and providence. In her more ecstatic praises, Evans appears to offer the promise of a spiritual inheritance that can surpass outward forms and human vanities. The poems often seem to address a world of the material, which is seen as ephemeral, and doomed to 'fade'. In the poem 'In the Cave of Abdullam' Evans draws upon the Old and New Testament in a dramatic version of David's time spent in the cave of 'shadows' before the promised arrival of his successor Emmanuel, symbolising the New Testament. Evans also sees the everyday journey on the 'great high-road of life' [Lines: 1-2] as beset by inner and outer foes or temptations. In the other poems a 'weary' world of material striving melts away. Human troubles can be surmounted by faith.

\section{A Little While}

A poem of four verses with rhyming couplets. The poem has a hymnal, even childlike quality, with an element of ambiguity in its opening verse: ('A little while - I go away/Waiting for the joy to follow/We are waiting still today' (Lines:1-4)). The poem's theme addresses the time between death and reunion. Jesus is the deliverer of hope and eternal rest. There is a period of purgatorial 'tribulation' until the glorious coming of the Master in the final stanza (is the 'wearying' on earth, or 'beyond' mortal existence?).

The 'exceeding glory' - seems to refer to a 'heavenly' state wherein 'sighing' will 'change to song' (Lines: 13-16)

"A little while you shall not see Me:

A little while - I go away".

Waiting for the joy to follow, We are waiting still today.

Wearying for the Master's coming-

Oh! The 'little while' seems long!

Till we see Him in his beauty,

And our sighing change to song.

In the "little while" is sorrow: 
Tribulation reigns a while.

Though he bade us, "be not troubled"-

Oh, how long "the little while".

Hasten then thy coming, Master,

For when once we see thee smile,

Safe within the "exceeding glory."

Short will seem "the little while".

\section{A Crown of Glory that Fadeth Not Away}

A 'rhetorical' poem of six verses with rhyming couplets. The poem looks to eternal values. Spiritual faith and salvation blend with natural imagery of the 'sublime' that looks beyond even the beauties of earth or the phenomenal world (Lines:1-4). The New Testament is referred to in the poem's exhortation of the coming of 'the Kingdom of the Lord!' (Line: 24) and the biblical 'gates of heaven' in 'Oh, for the gates of massive pearl!/Oh for the streets of gold' (Lines: 9-10). In the fifth verse, the world of the material is seen to fade as an awaiting 'unfolding' splendour emerges as a revelation.

The poem places faith in humanity's sharing of divine inheritance and salvation as seen in the poem's central image of the 'heavenly diadem' - or 'crown of glory' (Line: 1).

'Beyond the sunset's magic glow, Beyond all rose of morn,

Beyond the lights on sea and sky, When a new day is born.

Beyond the fleeting value

Of earthly gold and gem

We hold the unfading splendour

Of our heavenly diadem.

Oh, for the gates of massive pearl!

Oh for the streets of gold!

The glories that eye hath not seen, Nor human heart foretold.

Oh, for the water, crystal clear!

Life's river, flowing fair:

The trees with leaves which heal all ills

The nations carry there.

Beyond the failing radiance

Of earthly gold and gem

We count the unfading splendour 
Of our heavenly diadem.

All royal glories shall be ours,

When He shall speak the word,

"Come, in ye blessed, enter now

The Kingdom of thy Lord!"

\section{Shadows - New Years Day}

A poem of reflection, 'Shadows' is one of Evan's longer poems of six verses which addresses the world of the material or 'illusion'. The poem takes the theme of New Year celebrations to evoke a sense also of the delusionary that might tempt the 'weary' upon his 'highroad of life' (Line: 2). Although life can be formed of shadows, the Saviour shall enable all to 'see clearly' (Lines: 46-47). Mortal foes also constitute an 'illusion' that may be eventually overcome as 'foes' then turn into mere 'shadows': ('Half the foes who on our journey /Seem so potent and so strong/Are but shadows - passing shadows - /Which can never tarry long' (Lines: 25-26)). The theme of 'shadows' moves back and forth like a flickering candle. In changing their outward form they become 'phantoms' which, in their pursuance melt away: ('If we chase them, think we grasp them - Lo! Our hands hold empty air. Lines: 15-16)

'Somewhat weary, somewhat dusty, on the great high-road of life,

At this New Year I sit dreaming of the melee and the strife;

Dreaming also of the glamour, and the glitter, and the glow -

All that forms these earthly shadows which surround us as we go.

For our lives are thronged with shadows pressing closely on our way,

And they beckon us to follow, through the night and through the day.

Very sweet their siren song is, and their phantom forms how fair!

If we chase them, think we grasp them - lo! our hands hold empty air!

When a lovely face gleams on us, or a face we lovely call,

Don't we take it in our blindness, as sufficing all in all? 
Yet he very sure the truth is, that however wondrous fair,

Outward beauty is a shadow, if the inward beauty be not there.

Half the foes who on our journey seem so potent and so strong.

Are but shadows - passing shadows - which can never tarry long.

'Tis we who give our tempters frail the strength which THEIRS we call,

Yearning for a glory which is but a shadow after all.

One there is Who suffered for us; yea, for our sakes even died:

He, with calm and solemn gesture sweeps the shadows from our side.

Though we moan and weep bewailing, He will not for that delay,

Our weak hearts would spare our idols; God's great love can bear to slay.

This is love divine, majestic; strong as death and stronger far:

To us, groping in the darkness, this, our bright and morning star.

Christ says, "Weep not, my redeemed ones; short the night, soon breaks the day;

In the dawn ye shall see clearly, and the shadows flee away'.

\section{In the Cave of Abdullam}

'In the Cave of Abdullam' is a poem of 32 lines in rhyming couplets. Looking to the Old Testament and the Book of Samuel, the poem dramatises the life of the biblical David and his escape to the 'Cave of Abdullam'. The poem celebrates David's eventual victory over the forces attempting to overthrow him and the promise of continued salvation through his successor in Jesus Immanuel (New Testament). The poem begins with a quote from the Book of Samuel (xxii 1-3) and David's escape to the cave of Abdullam, where those 'in distress' gather around him and take shelter. In the first line 'dim in the midst of ages past' (Line: 1) David is seen as 'A shadowy figure in a cave, with foes on every hand' (Line: 3). Still awaiting his anointing as King he is 'Rejected, banished, yet a king, and waiting for his crown' (Lines: 4-5) However David is seen as 
the precursor to a 'mightier form' yet to come: ('Pass back, King David! Yield thy place to a far mightier form' [Lines: 17-18]). The poem then proclaims victory and salvation in the birth of Jesus ('Lo! Judah's Lion stands revealed! Immanuel is born!'. Immanuel's cave is seen as 'loftier' still (Line: 20). His capacity to 'save' will be yet greater than David's. There may also a be reference to the crucifixion in 'tender pierced hands' (Lines: 21-22). In the final stanza (23-29), Jesus as the inheritor of David's line embraces once again the same people as mentioned in the verse from the Book of Samuel: ('May all in debt, all in distress, and all who weary be/Come to the One Who casts none out, and find their rest in Three!' (Lines: 26-29))

David therefore departed thence and escaped to The Cave Abdullam ..... and everyone that was In distress and everyone that was in debt and Everyone that was discontented, gathered themselves Unto him and he became a captain over them ...' Samuel XX11 1+2

'Dim in the mists of ages past, we see King David Stand -

A shadowy figure in a cave, with foes on every hand; Rejected, banished, yet a King and waiting for his crown:

Destined to rise from depths of woe, to glory and renown,

Captain of all who were in debt, all whose distress was sore;

The discontented rallied round the standard which he bore;

Type of another waiting Chief, whose reign is yet to be,

Whose Kingdom lies in hearts of those who long His face to see.

Pass back, King David! Yield thy place to a far mightier form.

Lo! Judah's Lion stands revealed! Emmanuel is born!

The shadow of a grander King, within a loftier cave,

With tender pierced hands, Whose strength is infinite to save!

Oh, Royal Dweller in a cave! Oh Chief of David's line! 
Take all these aching hearts of ours; break them and make them Thine!

May all in debt, all in distress, and all who weary be,

Come to the One Who casts none out, and find their rest in thee!

\section{Until the Day Dawn}

'Until the Day Dawn' is a poem of 24 lines in rhyming couplets. It was one of Evans' poems to have been published separately in a local newspaper (ATL-MSX-39876). Another poem of hopefulness, 'Until the Day Dawn' once again introduces the image of 'shadows' and the flux of 'night and day'. There, the dispelling of darkness occurs in the coming of the light of dawn, for which the person of Jesus is the harbinger of light descending into a world of shadows. Those still living in the world of shadows have 'weary feet and weeping faces' (Line:3). The poem heralds the arrival of Jesus among mankind, as one who participates in the same. Using the image of the 'bright' and 'morning star' the poem sees the chains of the material darkness then broken.

'Oh, the Shadows! How they gather, as we press along our way!

Weary feet and weeping faces crowd the track on which we stray;

Year by year the gap grows wider, where some loved one gone before,

Once stood by us in our troubles made our aching hearts less sore.

Oh, the Shadows! Closer lie they as we ever onward Tread;

Memory only brings the lost ones, with the tender words they said.

Yet, the Master's words stand faithful, and our hearts aye, hold them true,

"Be not troubled; I go forward to prepare a place for you".

His is love divine, celestial; strong as death, and stronger far;

Now to us, who see but darkly, be our bright and morning star.

Christ says, "Weep not my redeemed ones; short the night, soon breaks the day;

In the dawn ye shall see clearly, and the shadows flee away.' 


\section{No Condemnation}

A poem in three rhyming stanzas 'No Condemnation' emphasises the Christian theme of the promise of salvation, or freedom from eternal judgment or 'condemnation', through

Christ's death. Here Evans reiterates the workings of Christian 'faith' wherein the follower of Christ may obtain spiritual safety and refuge: ('And what can part us from His love-our Refuge/Safe and sweet' [Lines:17-20]). The poem also appears to make the door 'opened' [Line: 14] for the seeking soul: ('The asker gains, the seeker finds, the door shall/Opened be/No soul shall e'er regret the hour it cast itself on/Thee' [Lines: 1316]).

Who shall condemn? 'Tis Christ that died: our Advocate is He.

Once dead, He lives for evermore. Who can resist

His plea?

Who shall lay aught to God's elect? Safe and Secure are those

Whose cause He condescends to plead, whom for His own He chose.

And shall not He Who gave His Son, give all things Else besides?

Come boldly to the Throne of Grace: thou wilt not Be denied.

The asker gains, the seeker finds, the door shall opened be.

No soul shall e'er regret the hour it cast itself on Thee.

And what can part us from His love-our Refuge safe and sweet-

Till dawns the day when we shall fall and worship at His feet?

Oh, more than conquerors through Thy love-from condemnation free!

In heaven and earth is nothing that can separate from Thee!

\section{Outside the Bay}

A poem in four rhyming stanzas, 'Outside the Bay' is in two sections with two verses each. In this poem, Evans employs a theme from 'romanticism', somewhat similar in 
tone to Coleridge's 'Ancient Mariner', of the 'dead man' drowned at sea: ('But all is there/Serene and fair/As the shells that toss in the dead man's hair' [Lines: 12-14]). It is both rhetorical and full of sea imagery with the 'tide' as the main subject prefacing each verse: '(The tide flows in and the tide ebbs out, and out in/the west afar' [Lines: 1-8-1523]). There is something of Evans' colonial milieu and her ship journey to New Zealand in the evincing, not only of the image of a tragic dead hero, but also the sadness of loss due to the perils of the sea on those left behind: ('The tide flows in and the tide ebbs out, and sad/Are the days to me' [Lines: 8-9]). However, in the final stanza, Evans again reiterates the theme of 'Faith' - this time using the 'morning star' as a metaphor for the dead man's resurrection 'from the grasp of the sea' [Line: 27] to live eternally. This final line brings together the connotations of 'romance' with biblical themes in the idea of the lovers' reunion in the 'City of Gold': ('In the city of gold he waits for me!' [Lines: $1-29]$.

'The tide flows in and the tide ebbs out, and out in the west afar

I see the lighthouse beacon flame like the flash of the evening star.

O light, shine bright!

Strike left and right!

For ships have been lost in the dead of the night!

The tide flows in and the tide ebbs out, and sad are the days to me:

No storms can move, and no winds disturb the depths of the deep, deep sea!

But all is there, Serene and fair

As the shells that toss in the dead man's hair.

The tide flows in and the tide ebbs out. Ah, no! He was drowned alone!

There is no one can point to his grave, and the sea

Has a heart of stone!

All the day long

Its pitiless song.

'I hold him fast in my caverns strong!' 
The tide flows in and the tide ebbs out, and out in

The east afar

I see the beacon of Faith light up like the flash of

The morning star.

From the grasp of the sea

God has set him free:

In the city of gold he waits for me!' [Lines: 1-29]

\section{This Life of Ours}

The final poem in the collection, 'This Life of Ours' has four rhyming stanzas. The poem is philosophical and reflective, using natural imagery to evoke Evans' understanding of life's 'pain and pleasure': ('This life of ours, what does it seem?/A little dream/Of pain and pleasure blent together' [Lines: 1-3]). The poem's opening lines express a need to give meaning to, or describe life's undercurrents, as in the following: ('A time of sharply changing weather/When brilliant sunbeams gleam and die/On heavy storm-clouds racing by' (Lines: 4-6)). In the third and fourth verses, Evans returns to the question of faith in God's providence which, if acknowledged, can offer respite from worldly sorrows or care: ('GOD KNOWS: on Him I roll my care/Night is not night if He be there' [Lines: 19-20]). The last lines once again point to an 'eternal day' which becomes an alternative to darkness and despair: ('Though daylight is no longer mine/And stars forbidden are to shine/I'll turn my eyes/To where eternal day shall rise?' [Lines: 21-24]. In this poem, Evans' personal belief in the souls' eternal existence appears to 'crown' the collection. The poem's last lines may have had particular meaning for her husband Eyre, who selected the poems for publication during World War I: ('That dawning light no earthly cloud/Shall quite enshroud./through all my fearsabove the range/Of every grief and every change/My faith can see with weary eye/The dawn of heaven on earth's dim sky' [Lines: 25-29].

'This life of ours, what does it seem?

A little dream

Of pain and pleasure blent together-

A time of sharply changing weather, When brilliant sunbeams gleam and die 
On heavy storm-clouds racing by;

And falling tears

Are bright with hopes, and cold with fears.

The years, the clouds have had their course;

Their mingled force

Has bowed my heart, and bent my head.

Sunshine and storm alike have fled,

And in their place a heavy gray

Dulls all the tinting of the day.

Shall growing light

Follow this gray, or deepening night?

What shall the future current be

Of life with me?

GOD KNOWS: on Him I roll my care-

Night is not night if $\mathrm{He}$ be there.

Though daylight is no longer mine,

And stars forbidden are to shine,

I'll turn my eyes

To where eternal day shall rise?

That dawning light no earthly cloud

Shall quite enshroud

Through all my fears-above the range

Of every grief and every change-

My faith can see with weary eye

The dawn of heaven on earth's dim sky,

And from afar

Shines on my soul the morning star!' [Lines: 1-32]

\section{Fragments of Poetry and Prose}

[ATL MS 13/19/1]

'Fragments of Poetry and Prose' is a small collection of miscellaneous writings in

Evans' own handscript. The 'fragments' include three unpublished poems: 'Too Late',

'There's a Woman at the Bottom of It' and 'All that Glitters is Not Gold'. The first poem, unlike the others, is in blank unrhymed verse. 'There's a Woman at the Bottom of It' and 'All that Glitters is Not Gold' are in rhyming couplets. These poems place a stronger emphasis on 'romance' elements than those in 'Poetic Gems'. 'Too Late' tells the story of a pair of lovers whose love must be tested by greed and worldliness. The hero declares his love but sees the girl as his possession, something that can be gained 
through becoming wealthy and rich, saying: 'The child is lovely, but she never looked before/As fair as now. Yes, I will marry her/When I am rich, and men will envy me' [Lines: 13-16]. He takes his leave of the girl he has chosen to be wife, leaving her with a token of his promise - a 'plucked rose' (Line: 18).

\section{Too Late}

The poem expresses the sorrow and remorse of a perfect love ruined by the desertion of the hero. In the first stanza, the poem's setting is full of a romantic luxuriance wherein the two 'ideal' lovers are seen framed together within the window of an 'ancient manor hall' [Lines: 1-2]. The images of the manor hall and the 'plucked rose' are each reminiscent of romantic medievalism [Line: 18]. The poem features a reversal of 'romance' convention in that the hero's triumphal reward from deeds of war and valour - ('The man fought bravely and with courage high/the world's great battle' [Lines: 3233]) - becomes tainted by his fall into desertion of his former love's memory ('But his heart grew hard/As his mind strengthened and when prosperous days/Repaid his ceaseless toil, and gave him ease/He had forgotten her' [Lines: 34-36]). Instead he chooses another bride, who in turn rejects him when his wealth has vanished ('So he knew his wealth was gone/And gone too was his bride' [Lines: 42-43]). As he retires to ponder his fate he is visited by a 'shadowy form', which is the spirit of his dead lover ('There hovered near, a vague and shadowy form/He knew it well - the face was very pale' [Lines: 56-57]. The pathetic figure still holds the rose symbolising her romantic steadfastness [Lines: 62-67]. After seeing the vision, the hero returns to the manor hall to find his love has died, but left behind a note pledging her love [Lines: 94-97]. The poem ends in a tender sweetness with the image of the bereft hero left to grieve and contemplate his lost love's grave by the 'small country church' over which 'violets grow o'er' [Lines:101-107]. The ending maintains the tone of Evans' other sentimental writing and re-echoes her theme of romantic union in 'the light celestial' [Line:107]. 
'In a deep window of the ancient Manor Hall

Talking and laughing lightly as their wont,

The setting sun cast his last rosy rays

On the bright valley - lying spread before

Their eyes regardless - all the country-side

Glowed brilliant: cornfields, groves and still it passed

Through the half-open lattice - trellised o'er

With summers's lovelist roses - flitted through

And cast a glory on her shapely head -

Steeping her rich luxuriant golden hair

With added lustre, till her sweet young face

Seemed almost more than mortal. And he gazed

At her, and thought within his heart 'the child

'Is lovely, but she never looked before'

'As fair as now. Yes, I will marry her'.

'When I am rich, and men will envy me'

'The wife that I have chosen. Bet it so.'

And then he plucked a rose and gave it her.

Saying with softened tone, and earnest look,

'I go tomorrow as thou know'st, to mine'.

'In the world's busy striefe. Forget me not, '

'But keep this flower in memory of me'.

'Keep it secure, and at some future day'

'Not very far within the time to come'

'I shall return, remind thee of this hour'

'And then if thou hast kept the rosebud still'

'Thou wilt be mine? ' The while he spoke, he stoop'd

And gazed into her eyes of violet blue

And then she knew she loved him.

On strode time'.

'Swiftly and pauselessly as he is wont.

The man fought bravely and with courage high

The world's great battle - but his heart grew hard

As his mind strengthened and when prosperous days

Repaid his ceaseless toil, and gave him ease

He had forgotten her.

Bright eyes smiled then

Upon him, so he chose the brightest pair(?)

The sawn(?) locks and haughty Queen-like face

And would have married, but ill news flew fast

With hasty steps outstripped the wedding morn.

So he knew his wealth was gone, and gone too

Was his bride; for she said coldly then,

'He could not ask her now, to keep her word.'

He did not, but he walked with a firm step

To his own home - that would be now no more -

And with locked door he pondered on his fate -

The labour of his manhood gone for nought;

His youth, and health were spent in vain, and all

His dreams of future happiness were dust

Beneath his feet. Sadly he bowed his head 
His pride gave way at last, his grief was sore,

But suddenly, with impulse undefined

He raised his eyes - and seeing and started back.

Before him, in the fast increasing gloom

There hovered near, a vague and shadowy form;

He knew it well - the face was very pale

And fair; the eyes met his reproachfully

With sad enquiry in their violet depths.

The tiny hand held forth a rosebud

Withered now - the parted lips appeared

To move, and then he thought, was sure, he caught

A whisper, faint, and soft, and very sweet.

'I have kept the flower so long - so long'

'Will he never come? I love him still'

'So much, so very much, but time drags slow.'

Then in the instant of a lightning flash

The face flamed into radiancy, and it seemed

As when the sunlight caught it long ago

His eyes sank blinded from the golden hair -

The glorious hair - one instant, only one,

But when he looked again, Behold! The form

Was gone.

Incredulously then he said

'A dream - a vision - but 'tis well it came.'

'I will go back to Mary - I will say'

'Forgive me - love me still. So noble is she'

'That I know she will receive me, let me'

'Call her wife. As for me - I shall forget'

'With her the past - her love will give me strength

'To flight anew'.

So he went to seek her,

And it chanced the time of year was that

In which he saw the valley last. All things

Looked just the same: the brilliant sunlight steeped

As east(?), the cornfields, groves, and peasants' home

The roses bloomed in loveliness beside

The small-paned lattice windows of this Hall -

All things remained as they had of old -

But she was dead.

They said she left a note

For him, in case he ever came. He tore

It open, and the words he found were these -

'My love - I know that thou wilt come some day'

'To fetch me, as thou saidst. I shall be gone'

'But grieve not thou for that. O! we shall meet'.

'Again, I know, I feel it will be so.'

'The rosebud will be buried by my side' -

'From that thou knows't that I was faithful to'

'The last'.

His grief was suffered years ago.

By the small country church her grave is green

Violets grow o'er it now. How like the eyes

That sleep beneath! Lovely he lives, but knows 
The time to join her is not far from hand

For in his dreams she often beckons him

The light celestial, on her face and hair'.

\section{There's a Woman at the Bottom of It}

This poem in six verses contains rhyming couplets and has an allegorical flavour. The poem refers to the Old Testament story of the 'fall' of Adam and Eve in the Garden of Eden ([Lines: 1-8]) and the 'patriarchal' image of woman as the receiver of Adam's blame. Evans, however, provides a striking contrast to this traditional concept of femininity while still maintaining the Victorian ideal of woman as the means to moral salvation. The poem's reprise 'the woman at the bottom of it all' is thus reversed in meaning from what might otherwise be intended ('Adam nobly laid the blame on Eve/As the woman at the bottom of it all' [Lines: 7-8]. The story of the 'fall' of Adam and Eve is therefore used to address relationships between men and women and man's faults and infidelities ('If a man is bent on going to the bad/He will manage it without a woman's aid/And, if he's not a scoundrel and a cad/He'll confess when his life's bill is being repaid' [Lines: 25-29]). Man is seen as weak in contrast to Woman who, not being entirely heartless, also exists to comfort and console ([Lines: 42-45]). The poem ends with the warning that men who want happiness and prosperity in marriage ought to appreciate their wives' good virtues ('And the (men) who've lived the best and noblest lives/Owe the fact that they stood fast and did not fail/To their mothers, and their sisters, and their wives' [Lines: 46-48]). In its underlying message, the poem bears a similarity to Chaucer's 'Wife of Bath' Tale.

'Once in Eden, in the days of long ago There lived a Man, a Woman, and a Snake And the Snake said: 'Don't you find it rather slow Living here without a Decalogue to break? 'Try those apples' And he chuckled in his sleeve The tale you very possibly recall, And how Adam nobly laid the blame on Eve, As the woman at the bottom of it all. 
And I think you'll find probably today

That the chivalry of men is much the same;

For he's just as much inclined to go astray,

And just as little apt to take the blame,

Of apples he is every bit as fond

As he was on those old days before the fall

And you'll find him just as ready to respond

'There's a woman at the bottom of it all'.

When a man had come quite hopelessly to grief,

And has drifted as we say, beyond the pale,

His friends are always firm in the belief

That there's quite another version of the tail.

'yes, he's proved himself a villain out and out

Still. He's had his a share of wormwood

And of gall.

And, when all is said and done, there's not a doubt

That a woman's at the bottom of it all.

If a man is bent on going to the bad,

He will manage it without a woman's aid,

And, if he's not a scoundrel and a cad,

He'll confess when his life's bill is being paid,

That, if sin has failed to lure him with its bait,

When the devil tried to get him in his thrall,

It was just a woman's love that kept him straight,

Yes, a woman at the bottom of it all'.

When his foot was on the ladder's lowest rung,

And his step as yet was faltering and blow

A woman's was the hand to which he clung;

She fanned his failing courage to a glow

And he knows (although he grudges to admit,

For at best his generosity is small)

That he owes his pluck and energy and grit

To the woman at the bottom of it all.

In the weary times of sickness and distress,

'tis a woman who has soothed his throbbed pain;

With a look, a word of love, or a caress,

She has lit his lamp of courage once again,

And the (men) who've lived the best and noblest lives

Owe the fact that they stood fast and did not fail,

To their mothers, and their sisters, and their wives,

To the women who have loved them best of all'.

\section{All that Glitters is not Gold}

In 'All that Glitters is not Gold' - a five verse poem in 27 lines - Evans addresses a

world of false appearances within a context of 'romance'. In this poem, the only one of 
Evans' to be locally published in newspapers, is the theme of 'choice' over material riches and that based on a truer love, as in the following: 'Before her, waiting for her choice were love, and wealth untold the treasures she cast by, and chose instead the gold' (Lines: 3-4). Following in 'romance' tradition the heroine must learn of her heart's mistake with remorse in Lines: 17-24.

'Oh! False and fickle was the dawn of whom I sing today But sore she cried in after years, the heart she threw away Before her, waiting for her choice were love, and wealth untold The seal treasure she cast by, and chose instead the gold.

She married well they said, and all, that $\mathrm{m}$....'s power could bring Was less unstinted from the day, she donned her wedding ring. But often when she eat alone, there rose up stern and bold, The phantom of the old old love, she threw away for gold.

With calm sad eyes it gazed at her, and thus it seemed to say 'You might have had a loyal heart - you bartered it away 'Your life is very splendid, but your life is very cold

Ah! Lady you may rue your choice, and like to curse your gold. The man who loved her deeply, who loved her now no more Fought bravely for his country's sake upon a foreign shore. She heard his name on every tongue, all lips his praises told, Was not a share in that brave life worth more than all the gold?

They met again at last, and oh! How fast her pulses beat!

She could have thrown herself with joy, remorseful at his feet. The eyes that coldly scanned her face, such calm indifference told Has balm to sooth that agony could not be bought for gold.

And His everlasting love which ensure us an

An entrance into Everlasting Life, I get

Hold that we are bound all the more

For this to show forth our faith by

Our works: to follow in his footsteps:

And let all men know that we are

His disciples by loving one another'.

\section{Contemporary Women Novelists}

An increase of interest in New Zealand novels has more recently enabled Evans to be viewed in context with other women writers of the period as defined in The Oxford History of New Zealand Literature as 'Early Colonial' 1861-1889 and 'Late Colonial' 
1890-1934 (Jones 134). Although Evans managed to achieve publication with the international publisher Sampson Low, Marston, Low \& Searle, her mainly intermittent writing career and domestic position likens her also somewhat to those 'amateurs' defined by Jones, who wrote and produced fiction that was 'at best an occasional avocation in the midst of lives dedicated primarily to the more material concerns of a pioneer society' (Jones 121).

Among Evans' women writer contemporaries is the well-known pioneer novelist and diarist Lady Mary Anne Barker whose works Station Life in New Zealand (1870) and Station Amusements in New Zealand (1873) (NZETC Collection) are now classics. Other pioneer period women novelists include the following:- Isabella J. Aylmer: Distant Homes: Or the Graham Family in New Zealand (1872 ) (NZETC); Emilia Marryat Norris: Amongst the Maoris: A Book of Adventure; Elizabeth Boyd-Bayley: A New Zealand Courtship and Other Work-A-Day Stories and Clara Cheeseman: A Rolling Stone Vols I-III (1886) (NZETC). Other women authors represented during the latter half of the, or 'Late Colonial Period' were Jessie Weston: Ko Méri, or, A Cycle of Cathay: A Story of New Zealand Life (1890); Eleanor C. Price: Mrs Lancaster's Rival; Louisa A. Baker: Wheat in the Ear (1898) and Edith Searle Grossman (NZETC). Along with other 'Early Pioneer' period novelists Evans' novels in particular focus on early rural settlement themes, with a marked vindication of the stabilising effects of marriage, courtship and property acquisition. This conservative optimism of Evans' was markedly in contrast with later developments in the New Zealand novel, such as the more psychologically and self-determining themes characteristic of Grossman and Baker's urban novels of the 'Late Colonial' era (Jones 135). Instead, Evans works more closely within the confines of popular escapist romance; maintaining her focus on the tightly woven sensation plot (Jones 125). Cheeseman and Norris, for example, weave their story lines in the more leisured style and tone of the popular easy to read epic. It is in 
these earliest examples of the New Zealand novel, that local scenery and people were exposed for the first time to an unknowing Empire readership. In their deployment of imagery and metaphor, Cheeseman and Norris enjoined with Evans at least to some extent, suggesting a yearning for the familiar amidst suggestions of the strange and uncanny. Along with Isabella Aylmer, another pioneer woman novelist of the 1870's, Cheeseman and Norris shared Evans' concern with the values and perceptions of English immigration and settlement in the rural frontier, set against an exotic backdrop of the indigenous and a peopled landscape of 'natives' or 'savages'. Corresponding perhaps even more directly with Evans' style as a popular romance novelist, were the escapist qualities to be found in Aylmers emigration tale of Distant Homes: Or the Graham Family in New Zealand.

\section{Pioneer Writer}

Ours was a decidedly lonely neighbourhood; and to us it seemed especially so when we first landed in New Zealand. - Our Nearest Neighbour

For Evans, writing in isolation was a pervasive dream. In Our Nearest Neighbour she wrote of the change of moving from 'a very social town' in England (1). During the years at Friston between 1867-1877 when most of her work was achieved, what was 'nearest' were then her own relatives; the in-laws settling into their homes on Tenaereaki Estate and even more evocatively, the saga of the Ogilvie-Grants and the Seafield Inheritance. Evans' evening hours spent at candlelight constituted an exercise of the literary sensibility, filling the gaps for more regular or wider reading habits. Inspiring her imagination was her own circle of relatives and their emigrations from more established or illustrious surroundings, such as the Evans' ancestral homes in Ireland. In their place were the realities of colonial station life presenting a new realm of 'frontier' romance. As a pioneer author Evans wrote on the periphery of the domestic, yet with the support of her husband and kin. Surrounding them were the hills of South 
Otago. It was a different and a separate life from that which they had previously known. In terms of the world of transtasman publishing, the novels, short stories and poetry Evans wrote between 1867 and 1882 constituted an initial attempt, in the form of romantic melodrama, at a conceptualisation of the frontier for which the natural forms and sensations of New Zealand life formed a backdrop.

New Zealand's $20^{\text {th }}$ century novelist Janet Frame also shared Evans' former domicile of Oamaru, moving there in 1931 at the age of 7 years with her family (King 25). In Toward the Is-Land Frame retraced her ancestors from Scotland and the Jersey Isles, seeing them as 'myth and reality' (7). Among her relatives was a poetess (also named 'Charlotte') who emigrated to New Zealand in the nineteenth century and to whom Frame was related on her mother's side. As 'Charlotte Nash' she was the author of a collection of poetry published in a 'small book with an engraved cover' (8). Frame recollected that the poems were 'written at eighteen before her [Charlotte Nash's] emigration from Harbledown, Kent, to New Zealand' (8).

Like the Evans at Friston Frame had a passion, along with her parents and siblings, for 'poetry and reading, writing, and reciting it' (9). During childhood she read works by early American novelists (contemporaries of Evans) such as Harriet Beecher Stowe and Henry Wadsworth Longfellow. Frame's mother Lottie was an amateur poet, contributing to the poetry section of the 'Wyndham Farmer' (20). Living in the 1930's at the farther reaches of Evans' 'Empire' New Zealand Frame's impressions included a visit by the Prince of Wales to Dunedin and occurrences of natural disaster in the flooding of St Kilda. The Eden Street of 1930's Oamaru provoked vivid sensations; of a new house and neighbourhood which were symptoms of agedness yet a 'treasure of new experiences' - of 'climbable' places, including a 'summer house' (that became a 'playhouse and theatre') (31)). At the top of a hill were 'caves and fossilised shells' - 
the reminders of a buried past. By then the town with its old 'stone buildings' and dilapidated quarter seemed a 'ghost city', yet a place nonetheless exciting in its rituals with a clock that chimed 'every quarter hour' (32). Frame's relationship as a school Dux medal subscriber with the forerunners of the 'Oamaru's Athenaeum and Mechanics Institute' symbolised too the latter end of a spectrum in Oamaru's development as a town with some pretension to Victorian grandeur. Established as a public lending library with a ground floor museum 'The Athenaeum was, similarly to the hill of caves, a form of extinct memory and hushed quiet (70). On the level above the museum ('feeling in awe of the world of books in a library') Frame extended her reading experiences in the Juvenile section, among which included her sister Myrtle's True Confessions and True Romances (71).

Representing an earlier and formative phase in Oamaru's history Evans has since earned her unique place as a settler author well situated in her locale. Writing for her 'romance' audience, Evans formulated fresh vistas by drawing upon the life at Teaneraki. In the Alexander Turnbull Library a few sheets of faded parchment now symbolise the isolation of that existence from the main centres of cultural Europe to which Evans refers in her 'Preface' for Over the Hills (ATL-MS 13-19-1). Reviews published of her writing (i.e. the novels) clearly saw Evans in pioneer terms, as a writer of fiction, and as a welcomed authoress, willing to transcribe the experience of European settlement in the colony. In her relatively brief lifetime, Evans was however unable to encompass fully the movements within her own circle, including that of the Ogilvie-Grants and the Seafield Inheritance - all of which had encapsulated for her more personally the spirit of romance across the seas, between colony and 'homeland'. As a writer of the early to mid-Victorian period, Evans epitomised some of its values; as did her immediate family the Lees, who, as builders of roads and railways and makers of local opinion, embodied a vigorous period in the construction of national identity (David 1). In her use of visual 
textures within the novel Evans followed in a Victorian spirit that sought to be 'generous', 'expansive' and always 'deeply entertaining' (David 2).

Although her novels were written and situated in the geographically isolated region of South Otago, New Zealand, Evans still participated in the Victorian novel's evolution and its debates concerning 'ideologies of gender, sexuality' and even the 'value of reading' itself (2). The light and entertaining tone of her works provided the vicarious flavour for an audience that was not highly literate - a milieu described by an 1887 critic as being uncritical, caring 'little for art for art's sake', but a readership 'ever widening' in its scope and needs (Flint 20). Evans' publication with a reputable firm such as Sampson Low at a time when publishers were reluctant to 'risk their capital' further reinforced her acumen as a writer of popular romantic fiction (20). It is now easy to overlook that Evans' work appeared at a time when purchasing fiction in hardback was expensive and even less likely to have been available during Oamaru's pioneer period (20).

A contemporary sideline to Evans' writing occurs also in her mention of colonial as a term of reference to be negotiated; its essential meaning needing somehow to be conveyed to a distant audience. In Over the Hills and Far Away Evans' mention of a story not 'too colonial in its language to be unintelligible' may have hinted at an underlying dilemma beyond the New Zealand exotic. For in stating her own case, which was the reality of being pioneer yet also of England, Evans sought to preserve appearances by saying that she was civilised, still alive and well, in a place which at least in the moment could only have been another version of 'home'. 


\section{Works Cited}

Armstrong, Nancy. 'Gender and the Victorian Novel.' The Cambridge Companion to the Victorian Novel. Ed. Deirdre David. Cambridge: Cambridge University Press, 2001

Arnold, Rollo. New Zealand's Burning: The Settlers' World in the Mid 1880's. Wellington: New Zealand Electronic Text Centre, 2005, http://www.nzetc.org/tm/scholarly/tei-ArnNewZ.html

Aylmer, Isabella, E. Distant Homes: Or the Graham Family in New Zealand. London: Frederick Warne and Co. London: Griffith and Farran, 1862.

Barker, Lady Mary Anne. Station Life in New Zealand. Auckland, New Zealand: Random House, 2000.

Bauld, Jean. Fragments of Poetry and Prose. The Story of Three Closely Linked New Zealand Colonial Families, Evans, Lees, Ogilvie-Grant, ATL-MS-13-19-1, Alexander Turnbull Library, Wellington, New Zealand.

Boyd Bayly, Elizabeth. Amongst the Maoris: A Book of Adventure. London: Frederick Warne and Co.

David, Deidre. Ed. The Cambridge Companion to the Victorian Novel. Cambridge Kingdom: Cambridge University Press, 2001. 
Evans, Charlotte. A Strange Friendship: A Story of New Zealand. London: Sampson Low, Marston, Low \& Searle, 1874.

Evans, Charlotte. 'Guy Eversley'. The North Otago Times. Oamaru: October-January, 1864-1865.

Evans Charlotte (Lees) 1841-1882. Literary papers ATL-MS-4426. Alexander Turnbull Library, Wellington, New Zealand.

Evans, Charlotte. Only a Woman's Hair (Three Short Novellas). London: Family Herald Press, 1903.

Evans, Charlotte. A Narrow Escape. London: Family Herald Press, 1900.

Evans, Charlotte. Our Nearest Neighbour. London: Family Herald Press, 1900.

Evans, Charlotte. Over the Hills and Far Away: A Story of New Zealand. London: Sampson Low, Marston, Low \& Searle, 1874.

Evans, Charlotte. Poetic Gems of Sacred Thought. Oamaru: J.H. Cunningham and Son, 1917.

Evans, Peter. Papers relating to the Evans, Lees and Grant Families. ATL- MS-Papers5135-09 and MSX-3976, Alexander Turnbull Library, Wellington, New Zealand.

Feather, John. A History of British Publishing. Abingdon, Oxon: Routledge, 2005. 
Flint, Kate. "The Victorian Novel and its Readers". The Cambridge Companion to the Victorian Novel. Ed. Deirdre David. Cambridge: Cambridge University Press, 2001

Frame, Janet. Janet Frame: An Autobiography. Auckland: Random House, 1989.

Jones, Lawrence. 'The Pioneer Novel.' The Oxford History of New Zealand Literature in English. Ed. Terry Sturm, $2^{\text {nd }}$ ed. Auckland: Oxford University Press, 1998.

King, Michael. Wrestling with the Angel: A Life of Janet Frame. Auckland: Penguin Books, 2000.

Moffat, Kirstine E. The Puritan Paradox: The Puritan Legacy in the Intellectual, Cultural and Social Life of New Zealand, Focusing Primarily on the Works of Novelists Writing between 1862 and 1940. Ph.D diss. Victoria University of Wellington.

Pykett, Lyn. 'Sensation and the Fantastic in the Victorian Novel.' The Cambridge Companion to the Victorian Novel. Ed. Deirdre David. Cambridge: Cambridge University Press, 2001.

Robinson, Roger and Wattie, Nelson. Eds. The Oxford Companion to New Zealand Literature. Auckland: Oxford University Press, 1998.

Skillbeck, Corry. Jottings of a Gentleman. Ashburton: MonoUnlimited, 2007. 
Stafford, Jane and Williams, Mark. Introduction: A Land Mild and Bold, Diffident and Pertinent. New Zealand Electronic Text Centre, New Zealand Novels Digital Collection, http://www.nzetc.org/tm/scholarly/subject-000005.html.

Stafford, Jane and Williams, Mark. Maoriland: New Zealand Literature 1872-1914. Wellington: Victoria University Press, 2006.

Thomas, Ronald R. "Detection in the Victorian Novel". The Cambridge Companion to the Victorian Novel. Ed. Deirdre David. United Kingdom: Cambridge University Press, 2001.

\section{Acknowledgement}

Beryl Miller, for genealogical information from the Oamaru Courthouse Records, Waitaki District Council, Oamaru.

\section{Links}

'The Nineteenth-Century New Zealand Novels Digital Collection' (NZETC) http://www.nzetc.org/tm/scholarly/subject-000005.html The North Otago Times, 1865-1874 Papers Past, http://paperspast.natlib.govt.nz. 'Canons of a Genteel Society' the North Otago Times, Volume XXI, Issue 988, 31 October 1874, Page 4 http://paperspast.natlib.govt.nz.

'Sensation Novels' the North Otago Times, Volume XXI, Issue 981, 15 October 1874, Page 2 http://paperspast.natlib.govt.nz.

'An Experienced Bigamist' the North Otago Times, Volume XVI, Issue 607, 14 March 1871, Page 3 http://paperspast.natlib.govt.nz.

'The Man with Two Wives' the North Otago Times, Volume XX, Issue 936, 15 May 1874, Page 4 http://paperspast.natlib.govt.nz.

'A Nice Character' the North Otago Times, Volume XX, Issue 939, 26 May 1874, Page 4 http://paperspast.natlib.govt.nz.

'Judge Richmond on "Colonialism" the North Otago Times, Volume XV, Issue 595, 31 January 1871 , page 3.

'Provincial Abuses and It's Remedy' the North Otago Times, Volume VIII, Issue 199, 9 April 1867, page 3. 


\section{Explanatory Notes}

\section{Text Footnotes: Over the Hills and Far Away: A Story of New Zealand}

The following consists of markup and glossing for the online version of the novel Over the Hills and Far Away. The footnoting is intended to offer explanatory assistance for interpreting names and placenames, items concerned with Victorian costume and custom, 'colonial' and foreign language terms and popular vernacular.

\section{References:}

OED: The Oxford English Dictionary

http://dictionary.oed.com

Te Ara: Encyclopaedia of New Zealand

www.teara.govt.New Zealand

DNZE: Harry Orsman, The Dictionary of New Zealand English:

A Dictionary of New Zealandisms On Historical Principles. Auckland: Oxford University Press, 1997.

\section{Page 1}

Brighton: a city on the south coast of England noted for its long promenade. A popular habitat among English middle and upper classes.

Grand Parade: name for the long promenade along the seafront of the City of Brighton.

\section{Page 2}

Chariots: name commonly associated with Roman times but used here in the context of Victorian horse-driven carriages.

Flora McDonald: Scottish name 'Flora MacDonald' is an actual historic character named after an eighteenth century Scottish Jacobite heroine famed for assisting the escape of Charles Edward Stuart (commonly known as 'Bonnie Prince Charlie') during the Jacobite rebellion. The name links to the history of early Scottish settlement in the region, see: Susan MacLean Kybett, Bonnie Prince Charlie: A Biography. London: Unwin Hyman, 1998.

\section{Page 3}

Colony: OED definition states: 'a settlement in a new country; a body of people who settle in a new locality, forming a community subject to or connected with their parent state; the community so formed, consisting of the original settlers and their descendants and successors, as long as the connexion with the parent state is kept up'. New Zealand was a British colony from 1840 to 1907 when it became a dominion, although from 1856 onwards it was effectively self-governing. See: http://www.teara.govt.New Zealand/en/government-and-nation/2 


\section{Page 4}

Esplanade: defined in OED as: 'a levelled piece of ground; often, such a space intended to serve as a public promenade'.

\section{Page 5}

Costume: Victorian vernacular for dress apparel - 'costume' has specific connotations with socially appropriate or expected forms of clothing defined in the Oxford English

Dictionary as 'the mode of personal attire and dress belonging to a nation, period or class'.

Parade: in the a busy thoroughfare filled with passing horses and carriages.

\section{Page 6}

Letters: mention of letters is also linked to the eighteenth-century 'epistolary' novel - an early example of the novel form in which letters are a narrative feature.

\section{Page 7}

Romance: 'romance' is also a literary genre. Used here to denote a felicitous 'passing' attachment consistent with romantic 'melodrama'.

Chemist's shop: formerly known as 'apothecary' - the use of the term 'chemist' in this context may reflect advancements in science and medicinal drugs.

\section{Page 8}

Plymouth: a major maritime city in south east England, Plymouth was a principal departure point for emigrants. Plymouth may have been familiar to the author who stayed in southern England before travelling to New Zealand in 1862. Further reference to Devon and Cornwall in New Zealand History Collection. See: http://www.New Zealandetc.org/tm/scholarly/subject-000001.html.

Dead letter office: repository for mail with incomplete address details its mention here could also have intended association with the mystery or suspense element found in this type of 'sensation' novel.

\section{Page 9}

Handsome: Victorian vernacular for pleasant or dignified appearance but not implying extreme beauty.

\section{Page 10}

Tombs: associated here with graveyards, tombs represent a particular Victorian preoccupation with 'gothic' or morbid subjects such as death and mortality. The tomb was therefore a common feature of 18th and novels and in particular the 'gothic romance'. 


\section{Page 11}

White Tombs: Victorian tombs of the wealthier classes often consisted of white marble and were ornate or simple according to family or dynastic associations. Also symbolic in sentimental literature which eulogised the death of the small child or innocence.

Railing: common feature in Victorian graveyards around graves.

\section{Page 12}

Charms: associated with talismanic protection, the word refers here more specifically to a decorative female fashion accessory. Charms are also traditionally linked to girdles and more recently wrist bracelets.

Locket: popular dress accessory dating to pre-Victorian times with strong sentimental and personal associations, the locket is a potent romance image.

\section{Page 14}

Diary: a common preoccupation in the Victorian era and often associated with ship travel.

Voyage: Further reference to emigration in other novels of the Literature collection. See: http://www.nzetc.org/tm/scholarly/subject-000005.html.

\section{Page 15}

Scenes: incidents described may be realistically drawn from the author's own shipboard experiences when travelling to New Zealand.

Forecastle: front part of a ship below deck.

Agent: advertisement for passenger ship agents feature in the North Otago Times, 6 October 1874. See: http://paperspast.natlib.govt.New Zealand

\section{Page 17}

Stern cabin: at rear of a ship or boat.

\section{Page 18}

Waverley Novels: one of a series of novels that were published by the early romantic novelist Sir Walter Scott between 1814 and 1831.

Bulwarks: extension of a ship's sides above sea level.

\section{Page 19}

Society: OED definition states: 'association or friendly interaction with other people; the company of others. Also in extended use with reference to animals or (occas.) plants'. 


\section{Page 20}

Coast: this nostalgic reference to the coast of Sussex is also reflected in the popular song 'The White Cliffs of Dover'.

Belaying pins: a device used on board ships comprised of solid metal or wooden bars. Used for attaching ropes. OED definition states: 'Naut. The coiling of running ropes round pins, etc'.

\section{Page 22}

Trawler:' OED definition states: 'a vessel employed in fishing with a trawl-net; now applied to a steam-trawler'.

Cliffs: direct reference to the white cliffs associated with the coast of Sussex.

\section{Page 23}

Leeward: on, or towards, the side sheltered from the wind or direction in which wind is blowing.

\section{Page 25}

Misanthropic: a person who dislikes and avoids other people.

Isle of Wight: small island and popular holiday resort off the coast of southern England.

\section{Page 26}

Morning Prayers: regular custom aboard ships. In 1912 passengers on the Titanic are said to have attended service shortly before the tragic sinking of the vessel.

English Church: meaning the Church of England or Anglican Church.

Devonshire: A region in the south of England, 'Devonshire' was the county of origin for numerous early British settlers. See New Zealand History section (NZETC collection), http://www.nzetc.org/tm/scholarly/subject-000001.html.

Gloamin': derived from Old English, meaning twilight or dusk.

\section{Page 27}

Languor: type of posture also suggestive of cultivated gentility or upper class attitude.

Doubles: probably a game of dice.

\section{Page 30}

Mystery: significant narrative element in the criminal or suspense aspect of sensation novels. 


\section{Page 32}

Lotus Eaters: a celebrated poem written by Alfred, Lord Tennyson in 1833 that was based around two early Greek epic poems The Iliad and The Odyssey both of which were attributed to the Greek poet 'Homer'. Tennyson's poem concerned 'Odysseus' the hero figure in Homer's Iliad. Tennyson was the British poet laureate between 1809-1892. See references to Tennyson and colonial reading in reports of The 'Oamaru Mechanics Institute' in the North Otago Times, http://paperspast.natlib.govt.New Zealand

\section{Page 41}

Dance: dancing classes were popular in the colony. See notice for 'Select Dancing Class' Oamaru. North Otago Times, Volume XXI, Issue 983, 20 October 1874, Page 4. See: http://paperspast.natlib.govt.New Zealand

\section{Page 45}

Mourning: OED definition states: 'the action of feeling or expressing sorrow, grief, or regret; sorrowing, lamentation; an instance of this'.

\section{Page 47}

Irony: OED definition states: 'a figure of speech in which the intended meaning is the opposite of that expressed by the words used; usually taking the form of sarcasm or ridicule in which laudatory expressions are used to imply condemnation or contempt'. See: http://dictionary.oed.com.

Grog: DNZE definition states: 'in the Brit. Sense 'spirits, esp. rum, and water'. See also the following: '1839 Lang New Zealand in 1839. The existence of a considerable European population and the artificial wants of the natives, have ..led.. also to the settlement of a swarm of individuals..of a very different description, as retail dealers, grogsellers, and panderers to the worst vices of the most abandoned of men'.

Baccy: slang for tobacco.

\section{Page 48}

Britannia: name for a Roman goddess and the title of a popular nationalist song 'Rule Britannia'. Sea themes also common in British ballads and songs.

\section{Page 49}

Pilot Coat: probably a form of overcoat worn by a pilot.

Languid indifference: a form of 'studied' posture.

\section{Page 53}

Piquant: refers to a quality that combines a sense of delicacy with interest or excitement.

\section{Page 54}

Black eyes: here 'eyes' are depicted as a means for 'seeing into' the person's character or 'soul'. 
Binnacle: a case or box on the deck of a ship.

Phosphorus: refers to a natural chemical reaction in the sea which emits a glow. Also derived from the Greek for 'light bearer'.

\section{Page 55}

Landseer: Sir Edwin Henry Landseer (1802-1803) a popular portrait artist of the Victorian era.

\section{Page 56}

Air: denoted here as an affectation of feeling typical of the literature of 'manners' of the 18 th and 19th centuries.

\section{Page 57}

Curse: this curse relating to a wife also links with similar theme in the novel 'Jane Eyre'.

\section{Page 58}

Saloon: on board ship a 'saloon' was a large room designed for the general recreation of passengers.

\section{Page 61}

Mackintosh: English term for a raincoat or type of waterproof clothing.

Second-class passengers: reference to 'emigrant stock' in New Zealand History section of the NZETC collection. See: http://www.nzetc.org/tm/scholarly/subject-000001.html.

\section{Page 62}

Mind: in literature the mind is linked to the personal imagination.

Information: theme linked with crime fiction and 'secrecy' in the sensation novel genre.

\section{Page 63}

Air: common expression for an indulgence in fantasy and imagination.

\section{Page 66}

Anodyne: here used to denote the means to relieve suffering in the least offensive way possible.

\section{Page 67}

Goose: Victorian expression for 'fool' or 'foolish'. 


\section{Page 69}

Cricket: a traditional English sporting past-time transported to the colonies, in particular to Canterbury, one of the earliest regions for English settlers in New Zealand. In Canterbury a cricket club was formed as early as 1851 , foreshadowing Canterbury's domination of the game. The New Zealand Cricket Council was formed in Christchurch in December 1894. See: http://www.teara.govt.New Zealand/en/government-and-nation/2.

\section{Page 70}

Cast looks: the 'coquette' is a flirtatious and sexually suggestive young woman.

Fortune: refers here to hopes of prosperity in the colony.

\section{Page 72}

Black: mourning continued as a ritual out in the colony. Clothes for mourning were advertised in the North Otago Times 6 October 1874. See:

http://paperspast.natlib.govt.New Zealand

\section{Page 74}

Jane Eyre: novel by the English novelist Charlotte Bronte, published in 1847, was a popularly read novel of Charlotte Evans' time period.

Lady: OED definition states: 'a woman having the characteristics traditionally associated with high social standing; a refined or genteel woman'.

\section{Page 76}

Lady Macbeth: the villaneous wife in Shakespeare's play Macbeth.

Maggie Tulliver: heroine, main character in George Eliot's novel Middlemarch set in 1820's England and published in 1874.

Mill on the Floss: novel by the English woman novelist George Eliot published in 1860.

\section{Page 77}

Cool: an 'aesthetic of attitude, behavior, comportment, appearance and style' - in this case an attitude of emotional reserve. See: The Concise Oxford Dictionary, ed. Judy Pearsal, Oxford: Oxford University Press, 2001.

Madeira: exotic locale geographically situated as an island or archipelago in the north Atlantic Ocean.

\section{Page 78}

Stern: the stern is the rear or 'aft' part of a ship or boat.

Latitude: gives the location of a place on Earth north or south of the equator. 
Saloon: large room on board ship for the relaxation of passengers.

Port Chalmers: main port of the city of Dunedin, Port Chalmers is located on a hilly peninsula and also the site of Dunedin's container port. Mentioned also in the North Otago Times, 1874. See: http://paperspast.natlib.govt.New Zealand.

\section{Page 79}

Paddock: OED definition states: 'a small field or enclosure, usually adjoining a house or farm building; esp. a piece of pasture in which horses or other animals are turned out to grass'.

Grass: Reference to growing of grass species in the new colony. In the North Otago Times, 6 October 1874. See: http://paperspast.natlib.govt.New Zealand.

\section{Page 80}

Maungarewa: A name derived from Maori language: 'Maunga' meaning 'mountain'. 'Rewa' meaning 'to float', to be 'high up'. See: www.maoridictionary.co.New Zealand.

Cornish boulders: large granite boulders are a common feature of the Cornish landscape with prehistoric associations. Also found on Oamaru coastline.

Robin Hood: popular figure also in English folklore celebrated in ballads and songs as a man who 'robs from the rich to give to the poor'. A memorial statue to Robin Hood exists in the city of Nottingham in Northern England.

\section{Page 82}

Gauntlet: $a$ form of riding glove.

Belle: refined woman from the French word 'belle' (beautiful) also linked to physical desirability, overall attractiveness and the social 'season'.

\section{Page 83}

Behaviour: linked to the medieval institution of Knighthood and the 'knightly' virtues of honour and courtly love.

Honour: meant to signify 'gentlemanly' behaviour and sexual restraint. See also note page 161.

\section{Page 84}

Cabbage-trees: Latin name 'cordyline australis' the cabbage tree is a well-known New Zealand native. Founded on a single stem with a forked crown of flowering branches. The leaves are sword shaped. Cabbage trees grow throughout the country, from sea level to about 1,000 metres, but are most common on the coast and lowlands. They grow singly or in groves on open forest margins as well as in swamps and along lake margins and river terraces. See: http://www.teara.govt.New Zealand/en/shrubs-and-small-trees-of-theforest/6. 
Flax: New Zealand flax is one of the country's most distinctive native plants. It has sword-shaped leaves 1-3 metres long that grow in a fan shape. As well as growing wild, flax has long been cultivated as a garden plant and a source of fibre. Latin name:

Phormium tenax and Phormium cookianum. See: http://www.teara.govt.New Zealand/en/flax-and-flax-working/1.

Brush: DNZE definition states: 'in occas. early New Zealand use as a shortened form of brushwood, in the sense 'scrub'.

Wildness: the Otago hill and mountain scenery is notable for its sparsely covered valleys and rivers.

Gully: DNZE definition states: 'the usual New Zealand word for a small ravine; a small, deep and steeply-sided valley; an eroded watercourse'.

Ravine: OED definition states: 'deep narrow gorge or cleft, esp. one formed by erosion by running water'.

Huts: poorer small type of shelter dwelling built of wood and used for various purposes in the colony.

\section{Page 85}

Co-raddies:_a form of native plant.

French bon-bons: a way of blending European associations with a native or 'indigenous' experience.

Colonial: meant as a distinguishing term which might sometimes be 'derogatory'. OED definition states: 'of, belonging to, or relating to a colony, or (spec.) the British colonies; in American history, of or belonging to the thirteen British colonies which became the United States, or to the time while they were still colonies. Now freq. derogatory. Also cited in DNZE definition as: 'an early name for usu. a non-Maori immigrant settler (also (rarely) a Maori settler or native-born New Zealander. (In non New Zealand use colonial often connotes inferiority). DNZE definition also cites as: '[AND 1808]. In usu. Pejorative, often jocular, use inferior in some respect, provincial, rough, makeshift'. Also a much discussed term in New Zealand. The term was cited in 1846 as follows: 'The very few persons who are not (to use the current expression) 'colonial' in their ideas and conduct, are neither understood nor estimated as they deserve to be, and as they would be in old countries'.

\section{Page 86}

Lassies: popular term to describe young Scots women.

Heart of Midlothian: name of a novel written by the romantic novelist Sir Walter Scott and the seventh of a collection known as the 'Waverley Novels'. Originally published in four volumes in 1818 .

\section{Page 87}

Toilet: in this context, washing or the use of cosmetic toiletries. 
Polonaise: style of fitted garment originating in the eighteenth century and later revived in the 1880 's.

Capital: desirable possession for intending emigrants, capital money allowed for land purchase and independence.

\section{Page 88}

Squatter: implies that the settler is well-to-do but has yet to have claimed legal ownership of the land. DNZE definition states: '[Orig. US squatter a settler with no legal title to the land occupied'.

\section{Page 92}

Flirtation: _see 'How to Woo and Win Her' in 'Poets' Corner' from North Otago Times'. Volume XXI, Issue 987, 29 October 1874, Page 4. See: http://paperspast.natlib.govt.New Zealand

\section{Page 107}

English mail: see Notice for postal services in 1874 North Otago Times. Papers Past. See: http://paperspast.natlib.govt.New Zealand.

Ocean: the geographic area in which New Zealand is situated, is also called 'Oceania'. New Zealand faces the Pacific on its eastern coastlines.

Masculine order: for references to 'masculinist' or male culture in the colonies refer to Literature Criticism and History section (NZETC collection), http://www.New Zealandetc.org/tm/scholarly/subject-000006.html

\section{Page 108}

Boarding establishments: local boarding houses provided accommodation for single men in colonial society. See North Otago Times 6 October 1874, http://paperspast.natlib.govt.New Zealand.

Young ladies: See 'The Canons of 'Genteel' Society', North Otago Times, Volume XXI, Issue 988, 31 October 1874, Page 4. See: http://paperspast.natlib.govt.New Zealand.

Water colours: a 'gentille' recreational pastime in English society. See ' New Zealand Artists: A Guide and Handbook' . See: http://www.New Zealandetc.org/tm/scholarly/search/search.html?text

Beef steak pies: beef was a primary New Zealand export well into the 20th century. With the development of the colony, New Zealand meat produce became a main export to Britain. See: http://www.New Zealandetc.org/tm/scholarly/search/search.html?text=meat+industry

Turkey: also a common Christmas meat dish.

Tennyson: See note page 32. 


\section{Page 109}

Gainers: meaning those who ought to prosper thereby.

Housekeeper: see also Station Life in New Zealand (1870) by Lady Mary Anne Barker. See: http://www.New Zealandetc.org/tm/scholarly/search/search.html?text=lady+barker

\section{Page 112}

Colonial politics: see column regarding provincial government in New Zealand in the North Otago Times, October 6 1874. See: http://paperspast.natlib.govt.New Zealand.

\section{Page 113}

Asperity: spoken in a sharp tone or with severity.

Black sheep: the 'black sheep' emigrant, not an uncommon character in the colonies, was often the youngest of the family or the 'disgraced' son of an aristocratic family. Also a character stereotype found in the New Zealand Novels Digital Collection. See http://www.New Zealandetc.org/tm/scholarly/subject-000005.html.

\section{Page 114}

Cavalry regiment: see New Zealand Novels Digital Collection for stories of regimental life in the colony, http://www.nzetc.org/tm/scholarly/subject-000005.html.

\section{Page 115}

Sublunary: refers to 'unconscious' or 'beneath the surface'.

Music: see letter about 'Choral Singing', North Otago Times, Volume XXI, Issue 977, 6 October 1874, Page 2. Also letter concerning 'The Organ Fund Concert', Volume XXI, Issue 997, 24 November 1874, Page 2. See:http://paperspast.natlib.govt.New Zealand..

\section{Page 116}

House: Dunedin houses were built of timber in imitation of English style homes. See Kirkpatrick, Glendining Co advertisement, 6 October 1874, North Otago Times. See: http://paperspast.natlib.govt.New Zealand.

\section{Page 117}

Reciprocity: a mutual exchange or 'rapport'.

\section{Page 120}

Waist: a small waist, often a desired feature of Victorian feminine beauty, was enhanced by tight corsetry. See: North Otago Times for advertisements for Womenswear October 6, 1874. See: http://paperspast.natlib.govt.New Zealand. 


\section{Page 121}

Sill: for more reading of 'idyllic' colonial homes and gardens see Distant Homes: Or the Graham Family in New Zealand by Isabella Aylmer see Literature section (NZETC collection), http://www.New Zealandetc.org/tm/scholarly/tei-AylDist.html.

Llewelyn: a Welsh name or originating in the country of Wales on Britain's West Coast.

\section{Page 122}

Gum-trees: a species of Australian native tree also imported to New Zealand (also the native habitat of the Australian 'koala' bear).

English stream: this passage is suggestive of the 'romantic' poem. See Keats' 'To a Nightingale'.

Bronchitis: a congestive illness affecting the lungs.

Vow: death and solemnity often feature in Victorian melodrama with biblical or christian themes. See also Literature and New Zealand History sections (NZETC collection) for mention of the christian church and Maoridom http://www.nzetc.org.

\section{Page 135}

Gold-fields: Otago was an early location for gold prospecting or 'digging'. See reference to gold exports in New Zealand History (NZETC collection), http://www.New Zealandetc.org/tm/scholarly/subject-000001.html

Nuggets: the generic term for a piece of 'prospected' gold usually discovered in riverbeds by the gold 'digger'.

Opossum-rug: the 'possum' is a tree climbing marsupial native to Australia but seen as a pest in New Zealand. Its thick fur however was, and still is, found useful. See: http://www.teara.govt.New Zealand/en/possums/1.

\section{Page 136}

Moa bones: Moa were large to very large birds that lived exclusively in New Zealand. They became extinct less than 600 years ago. They are classed as a member of the ratite group of birds, which includes the rheas (South America), ostriches (Africa and Europe-Asia), elephant birds (Madagascar), emus and cassowaries (Australia and Papua New Guinea) and kiwi (New Zealand). See: http://www.teara.govt.New Zealand $/ \mathrm{en} / \mathrm{moa} / 1$. The giant moa is now part of New Zealand legend.

Concert: see reference to local amateur concerts in 'The Organ Fund Concert' letter to the editor of the North Otago Times, Volume XXI, Issue 997, 24 November 1874, Page 2. See: http://paperspast.natlib.govt.New Zealand.

Mourned: mourning ritual and mourning clothes were observed and catered for early in the new colony. See: North Otago Times 1874, http://paperspast.natlib.govt.New Zealand. 


\section{Page 143}

Demi-toilet: not full 'formal' evening dress as would be the custom in Europe. See Evans' reference to this in her 'Preface' for the novel Over the Hills and Far Away in the Literature section (NZETC collection). See: http://www.New Zealandetc.org/tm/scholarly/subject-000005.html

\section{Page 145}

Entertainment: see North Otago Times for an example of community entertainment, 17 November 1874. See: http://paperspast.natlib.govt.New Zealand.

\section{Page 146}

Solo: the singing of light songs or 'lieder', sometimes with piano accompaniment, were a popular feature of society and brought to the colonies. There is evidence in New Zealand newspapers of early attempts to provide formal public musical entertainment. See: North Otago Times, 17 November 1874. See: http://paperspast.natlib.govt.New Zealand.

God Save the Queen: was the New Zealand 'national anthem' from 1840, also as 'God save the King'. Another anthem entitled 'God defend New Zealand' (written in 1874) was adopted as a national hymn in 1940 and in 1977 given equal status with 'God save the Queen'. A Māori translation is often sung before the English verses. See: http://www.teara.govt.New Zealand/en/government-and-nation/9.

\section{Page 147}

Lieder Ohne Worte: see Mendelssohn's 'Songs Without Words. See: Robert H.B. Hoskins, An Annotated Bibliography of New Zealand Songbooks. Christchurch, N.Z: School of Music, University of Canterbury, 1988.

\section{Page 150}

Pearl-Grey Silk: see 'In the Silk Department', North Otago Times, 6 October 1874. See: http://paperspast.natlib.govt.New Zealand.

\section{Page 151}

Dinner: DNZE definition states: 'the midday meal whether the main meal of the day (as often in rural New Zealand) or not (as is usual in towns). Also cited: 'As elsewhere and esp. in urban use, a main meal taken at evening'. Also: local hoteliers and dining rooms in Evans' home of Oamaru advertised their dining hours from $12-2$ in the afternoon. See North Otago Times, 6 October 1874, page 3, http://paperspast.natlib.govt.New Zealand.

\section{Page 163}

embarras des richesses: French, meaning a surfeit of fortune or literally an embarrassment of riches.

\section{Page 167}

Good faith: meaning 'implicit' trust. 
Pon my honour: Literally translated 'upon my honour'. OED definition of honour states: 'as received, gained, held, or enjoyed: Glory, renown, fame; credit, reputation, good name. The opposite of dishonour, disgrace'.

\section{Page 168}

Iron hand: could this also be a form of parody on the male stereotype?

Conversation: the art and therefore the consequences of conversation also constituted a significant aspect of the late eighteenth century novel such as found in the works of English novelist Jane Austen.

\section{Page 170}

All that glitters is not gold': a traditional proverb meaning that superficial appearances may be deceiving.

Caressing deference: could also read as sexual 'double entendre'.

\section{Page 172}

Equivocating: meaning neither one thing nor another.

\section{Page 181}

Madeira: an island situated in the North Atlantic Ocean discovered by the Portugese in the 15 th century.

Pour passer le temps: French, for "filling in" or "passing time away".

Making love: in Victorian vernacular referring more to an affectionate, romantic (rather than overtly physical or sexual) response.

\section{Page 186}

Apple-trees: an early imported fruit tree in the colonies. Apples and pears have been grown in New Zealand since the first arrival of Europeans to the country. The missionary Samuel Marsden introduced the first apple and pear trees in 1819. See: http://www.teara.govt.New Zealand/en/government-and-nation/2

\section{Page 188}

Tropics: the long ship journey to the antipodes involved crossing through the 'tropical' regions between the Northern and Southern hemispheres.

Ribson pippins: a brand of apple.

\section{Page 192}

Diptheria: a bacterial infection occurring in unsanitary or crowded conditions. More common in Europe and therefore the colonies prior to immunization. 


\section{Page 193}

Doctors: see reference to 'Hospitals and Early Hospitals in New Zealand' in New Zealand History section in the NZETC collection: http://www.New

Zealandetc.org/tm/scholarly/search/search.html?page-length=10\&text=hospitals

\section{Page 194}

Robin Hood: name of the horse.

\section{Page 197}

Tussock: New Zealand's native grasslands are dominated by tussocks which are grasses that have a clumping growth form. In the colonising period of New Zealand, farmers burnt off large areas of tussock and tried to replace it with imported grasses. See: http://www.teara.govt.New Zealand/en/government-and-nation/2

Agricultural show: an inherited agricultural tradition at which local farming produce and animals are exhibited, takes place over the summer months in New Zealand. See: North Otago Times, http://paperspast.natlib.govt.New Zealand.

\section{Page 198}

Bachelors: here Evans appears to give a vivid image of symbols of indoor masculinity.

\section{Page 200}

Volumes: implies the significance of imported fiction reading in the colonies. Colonial readers were often reputed to be at least as 'informed' of the latest works as those readers still 'at home'.

Kingsley: English novelist Charles Kingsley, 1819-1875.

Macaulay: the English historian Thomas Babington Macaulay, 1800-1859.

Thackeray: the English novelist William Makepeace Thackeray, 1811-1864.

Dickens: the English novelist Charles Dickens, 1812-1870.

Clytie: or 'Clytia' a water nymph in Greek mythology and lover of the God 'Apollo'

\section{Page 206}

Flax-plants: See note page 84.

Cabbage-tree: see note, page 84

Paradise: see further references to the New Zealand colony as envisaged by Edward Gibbon Wakefield in New Zealand History section in the NZETC collection, http://www.nzetc.org. 


\section{Page 231}

Croquet: a game using a ball and wooden mallet highly popular in England in the . Played by both men and women croquet was also a competitive sport and featured at the 1900 Summer Olympics.

\section{Page 243}

Concern: probably a form of decorative accessory.

\section{Page 245}

Rose: among the first importation of flower species into New Zealand bearing strong symbolic association with the 'homeland'. A summer flower, the rose blooms in New Zealand during the northern winter.

\section{Page 246}

Honeysuckle: a form of sweet smelling weed was a familiar decorative vine for early New Zealand timber homes, also growing prolifically in hedges planted by the colonists.

\section{Page 248}

Dawlish Bay: on the Wessex coast of Southern England situated near the town of Dawlish. The area is noted for its red sandstone rock.

Plymouth Hoe: open space situated in the city of Plymouth on the English southern coast. The area is near limestone cliffs forming the seafront with views out to Plymouth Sound.

\section{Page 249}

Bolt-head: headland on the south coast of Devon now owned by the National Trust and situated west of the Kingsbridge Estuary.

Decanter: pouring vessel made from cut class and a familiar feature of drawing room entertaining.

\section{Page 253}

Wattle: wild yellow coloured flower native to Australia and now known as Australia's floral emblem. A Wattle Club was founded in the State of Victoria in 1889.

Gorse: wild growing flowering prickle native to Scotland and imported into New Zealand with the colonists soon became a pest weed. The Otago region was settled early by Scottish settlers.

\section{Page 294}

Married: see reference to bigamy in 'An Extraordinary Bigamy Case' North Otago Times, Volume XXI, Issue 1007, 17 December 1874, Page 2. See: http://paperspast.natlib.govt.New Zealand. 


\section{Page 310}

Attitude: suggesting an artificial stance aimed to create an impression. Is Evans attempting to be sardonic?

\section{Page 319}

Golden city: probably symbolising a spiritual or 'heavenly' home or 'state'.

Redeemer: Christ - his death is believed by Christians to redeem humankind.

\section{Page 321}

Eton: an upper-class English boys' preparatory school situated at Windsor.

Lord's: main cricket ground in St John's Wood, London, at which major matches are held over summer.

Oxford: name of a university situated in the same town called 'Oxford' situated near Cambridge University in the county of Buckinghamshire.

Profession: Dacre is decorated with the conventional symbols of class and 'success' reflecting the gentility of Evans' chosen characters.

\section{Page 323}

English mail: see also reference to same in North Otago Times, 20 October 1874. See: http://paperspast.natlib.govt.New Zealand.

\section{Page 326}

Glory: may denote the fulfilment of some state of love felt by Lucy. In this context however it does not infer sexual passion.

\section{Page 327}

Hymn: Hymn singing was a feature of colonial life. Early rural settlers often would make their own music. All families would sing hymns or Gilbert and Sullivan songs around the piano, while out in the men's quarters concertinas or accordions accompanied a good singalong of shanties and folk songs. See: http://www.teara.govt.New Zealand/en/rural-recreation/1.

\section{Page 328}

Glory: may here imply the Victorian Christian's belief in life after death as an image of spiritual hope and salvation. 
Text Footnotes: A Strange Friendship: A Story of New Zealand

\section{References:}

OED: The Oxford English Dictionary.

http://dictionary.oed.com

Te Ara: Encyclopaedia of New Zealand

www.teara.govt.New Zealand

DNZE: Harry Orsman, The Dictionary of New Zealand English:

A Dictionary of New Zealandisms On Historical Principles, Auckland: Oxford University Press, 1997.

\section{Page 1}

Sussex: a county situated on the south east coast of England.

\section{Page 7}

Bachelors: OED definition states: 'An unmarried man (of marriageable age)'. Bachelors or 'single' men were common in the early settlement of the New Zealand colony.

Quaker: also known as 'The Religious Society of Friends' the Quaker movement was founded in the 17th century. Quakers were also prominent in the early settlement of the United States, particularly in the region of Pennsylvania. They are traditionally noted for an emphasis on plain appearance, frugality and adherence to humanitarian principles.

\section{Page 9}

Coral chain: a 'clue' in the crime sub-plot, also a feature of sensation writing.

Locket: a 'clue' in the crime sub-plot, also a feature of sensation writing.

\section{Page 14}

Madelaine: a surrogate name for Richard Carewe.

\section{Page 15}

Idylls of the King: Poetic sequence by Tennyson concerning the life of the legendary King Arthur, published between 1856 and 1885.

Holy Grail: the subject of the Holy Grail is a central theme in the tale of King Arthur's 'Camelot'. However the idealism of the Holy Grail may in this context be more suggestive of satire.

\section{Page 16}

Muslin: a popular light textured summer fabric in women's clothing both in England and the colonies. 
Modiste: see the author's own reference to European fashions in the colonies in the Preface to Over the Hills and Far Away.

\section{Page 20}

Culinary department: see also references to the colonial domestic in advertisements in the North Otago Times, 1874. See: http://paperspast.natlib.govt.New Zealand.

Holland aprons: A 'holland apron' is associated with a form of apron which 'loop's over the neck. OED definition for 'apron' states: 'An article of dress, originally of linen, but now also of stuff, leather, or other material, worn in front of the body, to protect the clothes from dirt or injury, or simply as a covering'.

\section{Page 21}

Earthly paradise: see references to the pastoral ideal in Edward Gibbon Wakefield's emigration policies in New Zealand History section (NZETC collection). See: http://www.New Zealandetc.org/tm/scholarly/subject-000001.html.

\section{Page 22}

Piano: a middle-class luxury in the colonial homestead suggesting gentility and privilege.

Geraniums: a species of flower. OED definition states: 'A genus of herbaceous plants or undershrubs (family Geraniacex, of which it is the type), growing wild in temperate regions, and bearing a fruit similar in shape to the bill of a crane; a plant of this genus or its flower'. Early settlers imported flora and fauna from what they termed 'home' creating a contrast to the native bush which often bordered the early colonial dwelling.

Work-baskets: a haberdashery container of cottons and needles for women working embroidery. Here the mention of 'dainty' also signifies needlework and embroidery as a 'gentille' occupation for ladies of refinement or leisure.

Curtains: chintz is often mentioned as a popular fabric in early colonial furnishings. OED definition for 'chintz' fabric states: 'orig. A name for the painted or stained calicoes imported from India; now, a name for cotton cloths fast-printed with designs of flowers, etc., in a number of colours, generally not less than five, and usually glazed'.

Carpet: a luxury item in early colonial homes whose interior furnishings consisted more commonly of bare floors and matting.

\section{Page 23}

Household comforts: see Papers Past Advertisements for 1874, http://paperspast.natlib.govt.New Zealand.

Class: despite the egalitarian ideal of the colony, the subject of class still existed between settlers. See records of passenger ship arrivals in North Otago Times, 1874. See: http://paperspast.natlib.govt.New Zealand. 


\section{Page 25}

Creeks: New Zealand vernacular for the English 'stream'. OED definition for 'creek' states: 'As part of a river or river-system. a. An inlet or short arm of a river, such as runs up into the widened mouth of a ditch or small stream, or fills any short ravine or cutting that joins the river. A reference to use of term 'creek' circa 1889 goes as follows: 'What they call a brook or brooklet or a streamlet or a rill, I do only, I confess its, call a creek and always will'. See: Orsman, H. The Dictionary of New Zealand English: A Dictionary of New Zealandisms On Historical Principles. Auckland: Oxford University Press, 1997.

Maoris: indigenous inhabitants of New Zealand.

\section{Page 26}

Sitting-room: the most common living area in the colonial dwelling. See mention of furnishing and objects in text.

Mountains: New Zealand is a naturally mountainous country the highest of which are Southern Alps located in the South Island. This story is realistically located in the Otago region of the lower South Island.

\section{Page 27}

Maiden: here Evans is using a feminine metaphor with which to describe local landscape.

\section{Page 28}

'Queen Rose': one of the earliest flower species to be introduced by English settlers. See also Isabella Aylmer's Distant Homes: The Graham Family in New Zealand in Literature section (NZETC collection): http://www.nzetc.org.

\section{Page 30}

Gentleman: ideas of class and gentility are significant in Evans' novels, but not necessarily representative of wider settler attitudes.

Gauntlet: A form of glove and traditional feature of riding attire.

\section{Page 34}

Verandah: DNZE definition states:'an opensided roofed structure attached to a house', not exclusively of New Zealand, but a common local architectural feature (recorded from 1834): also occas. transferred to the porch-like over-hang in the front of a Maori meeting or other house.

\section{Page 35}

Patrician: OED definition states: 'gen. A person of noble birth or rank, an aristocrat; a person of high social status, esp. one from an established wealthy family; a member of the upper classes'.

Knick-knacks: indicates the significance attached to sentimental items by colonists 
Embroideries: traditionally identified with female domestic leisure pursuits of the middle and upper classes.

\section{Page 36}

Furniture: see advertisements in Papers Past, North Otago Times for 1874.

Opossum: an imported marsupial of Australian origin now regarded as a pest in New Zealand, the opossum is still used for local fur merchandise. The name 'opossum'applies strictly to the true American opossum (family of Didelphidae). The opossum, now so well established in New Zealand, belongs to the tree-dwellers of the genus Trichosurus..(bush-tailed opossum). See: http://www.teara.govt.New Zealand/search?

Damask: a luxury item in the early colony

Beautifully-bound volumes: books were an expensive item in mid-Victorian New Zealand with circulating libraries at a minimum.

\section{Page 45}

Station: common term for a substantial piece of settler owned land. DNZE definition states: 'the homestead usually with the headquarters buildings and amenities of a larger grazing property'

Curtis Knowle: name for the Carewe estate back in England.

\section{Page 47}

Womankind: marriageable women were at a premium during the early pioneering days of settlement.

\section{Page 48}

Quaker sister Dorothea: Quakers are commonly known as 'the Religious Society of Friends' a movement originating in England during the 17th century. Quakers are known for their values of simplicity and 'plain' dress.

\section{Page 51}

Coarsely-furnished: in colonial style living 'coarseness' was usually typical of the rougher type of dwellings such as 'huts' or 'schacks' lived in by the very poor settlers (often itinerant workers).

\section{Page 55}

Whitest: paleness of skin was traditionally thought a feature of beauty in early English literature such as the medieval and Elizabethan periods.

\section{Page 58}

Paradise: New Zealand was historically thought of as a 'pastoral paradise' in imitation of England. See references to Edward Gibbon Wakefield migrations in New Zealand 
History section (NZETC collection): http://www.New

Zealandetc.org/tm/scholarly/subject-000001.html

\section{Page 59}

Faultless figure: a 'perfect' or small waisted figure was thought highly desirable when women wore tight corsets to achieve the same effect.

Affected: refers to an air of artifice.

\section{Page 60}

Accomplishments: traditional feminine social accomplishments included piano playing, singing and needlework hence the importance attached to the possession of a piano in Evans' novels.

\section{Page 62}

Picnic: outdoor colonial picnics are mentioned in other pioneer novels. See Lady Barker's Station Life in New Zealand in Literature section (NZETC collection). See: http://www.New Zealandetc.org/tm/scholarly/subject-000005.html

Events: organised social activities regularly featured in local Oamaru newspapers. See North Otago Times, see: Papers Past, 1874. See: http://paperspast.natlib.govt.New Zealand.

\section{Page 100}

Auckland: the largest city of the North Island of New Zealand situated between the Hauraki Gulf and the Manukau Harbour. Auckland was founded in 1840 by Captain Hobson on 18 September 1840. In the 1800's Auckland established its position as a financial and industrial centre. See: http://www.teara.govt.New

Zealand/search?keys=auckland+city\&form

Mail: a vital point of communication in the early colony. The New Zealand Post Office was set up in the 1840s, but until the 1860s services were infrequent because poor roads made it difficult to carry mail to settlements. Horses and horse-drawn coaches transported mail until the 1920s. See: http://www.teara.govt.New Zealand/en/rural-services/5

\section{Page 101}

Work basket: routine mending was not only a servant's task.

\section{Page 103}

Garibaldi: a form of jacket worn in the Victorian period, the 'garibaldi' was named after the Italian revolutionary Guiseppe Garibaldi who visited England in 1863.

Panniken: OED definition states: 'a small pan or drinking vessel of earthenware or (now usually) metal; the contents of such a vessel, a drink. Also in extended use.a small type of canister'. 


\section{Page 104}

Kitchens: household supplies were widely advertised in local newspapers, see: North Otago Times 1800's. See: http://paperspast.natlib.govt.New Zealand.

Effeminate: meaning feminine or 'feminised'.

Swag: a colloquial term for carry bag common to Australian folklore. DNZE definition states: 'a blanket-wrapped roll or bundle of possessions and useful articles, which when carried by a traveller on foot, was usu. held by straps to the back or shoulders, or laid around the neck like a horse-collar'.

\section{Page 176}

Continent: a term for Europe or continental Europe.

\section{Page 178}

Melbourne: travellers to New Zealand frequently arrived via Australian cities such as Melbourne. The city, situated in the state of Victoria, was declared an administrative capital by Governor Bourke in 1836. The city peaked in the 1880s during the economic boom of the Victorian gold rush.

\section{Page 180}

Scamp: OED definition states: 'A good-for-nothing, worthless person, a ne'er-do-well, 'waster'; a rascal. Also playfully as a mild term of reproof'.

\section{Page 182}

Agreement: the hidden aspect to the sub-plot of Madame Ainsleigh's disguise.

\section{Page 201}

Maidservant: letters of Evans' relative Alice Lees also refer to 'servant girls'. Alice lived in the same area of Oamaru as Evans during the 1806's and 1870's.

Lassie: a Scottish term for young unmarried woman. OED definition states: 'lassiehood, girlhood. lassieish $a$., young-womanish'.

\section{Page 203}

Flood: a common occurrence in pioneer New Zealand. See New Zealand History section (NZETC collection), http://www.New

Zealandetc.org/tm/scholarly/search/search.html?text=flood.

\section{Page 241}

Catastrophe: similar reports were published in the North Otago Times. See: http://paperspast.natlib.govt.New Zealand.

Body: scandal, deaths and murder featured in newspaper articles. See: North Otago Times, http://paperspast.natlib.govt.New Zealand. 
Page 243

Creeks: See note page 25.

Page 245

Rich: note the hint of 'double entendre'.

Innocent: double entendre on 'innocent'. 